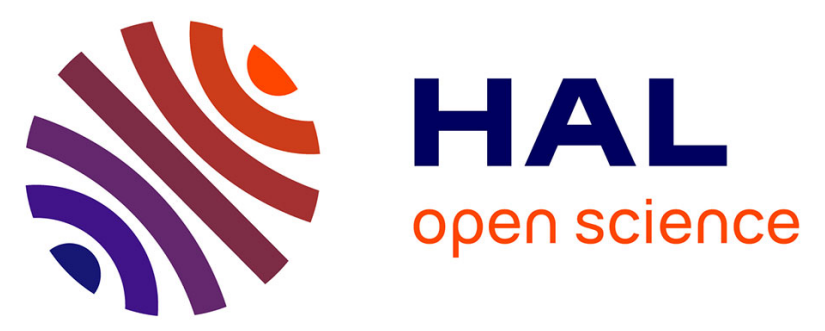

\title{
Central Asian moisture modulated by proto-Paratethys Sea incursions since the early Eocene
}

Niels Meijer, Guillaume Dupont-Nivet, Hemmo A. Abels, Mustafa Kaya, Alexis Licht, Meimei Xiao, Yang Zhang, Pierrick Roperch, Marc Poujol, Zhongping Lai, et al.

\section{To cite this version:}

Niels Meijer, Guillaume Dupont-Nivet, Hemmo A. Abels, Mustafa Kaya, Alexis Licht, et al.. Central Asian moisture modulated by proto-Paratethys Sea incursions since the early Eocene. Earth and Planetary Science Letters, 2019, 510, pp.73-84. 10.1016/j.epsl.2018.12.031 . insu-01990317

\section{HAL Id: insu-01990317 https://hal-insu.archives-ouvertes.fr/insu-01990317}

Submitted on 16 Nov 2020

HAL is a multi-disciplinary open access archive for the deposit and dissemination of scientific research documents, whether they are published or not. The documents may come from teaching and research institutions in France or abroad, or from public or private research centers.
L'archive ouverte pluridisciplinaire HAL, est destinée au dépôt et à la diffusion de documents scientifiques de niveau recherche, publiés ou non, émanant des établissements d'enseignement et de recherche français ou étrangers, des laboratoires publics ou privés. 
Article published in Earth and Planetary Science Letters

Niels Meijer, Guillaume Dupont-Nivet, Hemmo Abels, Mustafa Kaya, Alexis Licht, et al.. Central Asian moisture modulated by proto-Paratethys Sea incursions since the early Eocene. Earth and Planetary Science Letters, Elsevier, 2019, 510, pp.7384. 〈10.1016/j.epsl.2018.12.031〉. 〈insu-01990317〉 


\section{Central Asian moisture modulated by proto-Paratethys Sea incursions since the early Eocene}

Niels Meijer; Guillaume Dupont-Nivetabc; Hemmo A. Abels ${ }^{\mathrm{d}}$; Mustafa Y.Kaya; Alexis Lichte; Meimei Xiaof; Yang Zhangc; Pierrick Roperchb; Marc Poujolb; Zhongping Laig; Zhaojie $\mathrm{Guo}^{\mathrm{c}}$

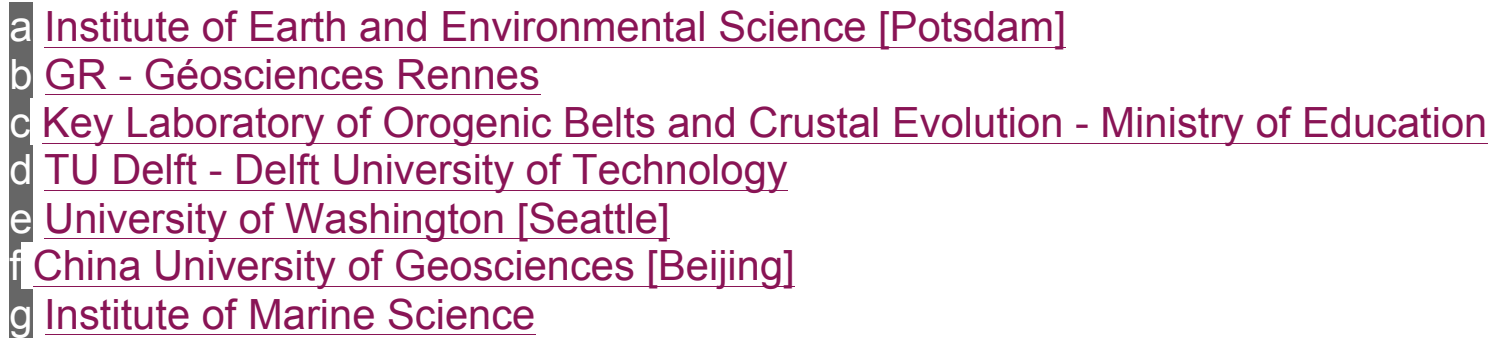

\section{Abstract}

The establishment and evolution of the Asian monsoons and arid interior have been linked to uplift of the Tibetan Plateau, retreat of the inland proto-Paratethys Sea and global cooling during the Cenozoic. However, the respective role of these driving mechanisms remains poorly constrained. This is partly due to a lack of continental records covering the key Eocene epoch marked by the onset of Tibetan Plateau uplift, proto-Paratethys Sea incursions and long-term global cooling. In this study, we reconstruct paleoenvironments in the Xining Basin, NE Tibet, to show a long-term drying of the Asian continental interior from the early Eocene to the Oligocene. Superimposed on this trend are three alternations between arid mudflat and wetter saline lake intervals, which are interpreted to reflect atmospheric moisture fluctuations in the basin. We date these fluctuations using magnetostratigraphy and the radiometric age of an intercalated tuff layer. The first saline lake interval is tentatively constrained to the late Paleocene-early Eocene. The other two are firmly dated between 46 Ma (top magnetochron C21n) and $\sim 41$ Ma (base C18r) and between $\sim 40$ Ma (base C18n) and $\sim 37 \mathrm{Ma}$ (top C17n). Remarkably, these phases correlate in time with highstands of the proto-Paratethys Sea. This strongly suggests that these sea incursions enhanced westerly moisture supply as far inland as the Xining Basin. We conclude that the proto- 
Paratethys Sea constituted a key driver of Asian climate and should be considered in model and proxy interpretations.

Keywords Paleogene; magnetostratigraphy; Central Asia; Xining Basin;westerlies;Asian monsoon

\section{Introduction}

Asia's modern-day climate is characterized by monsoons and inland deserts, but the timing and mechanism of their origin remains controversial. Both have been linked to the uplift of the Tibetan Plateau, the retreat of the proto-Paratethys Sea from Eurasia and the cooling of global climate (e.g. Ramstein et al., 1997, Dupont-Nivet et al., 2007, Zhang et al., 2007). Uplift of the Plateau would create orographic barriers and intensify monsoonal circulation by increasing thermal contrasts and insulating southern moist air (e.g. Molnar et al., 2010). Retreat of the proto-Paratethys Sea would remove a significant source of moisture from the Asian interior (Ramstein et al., 1997, Zhang et al., 2007; Bosboom et al., 2014a, Bosboom et al., 2014b; Bougeois et al., 2018) and may have strengthened the monsoons by increasing land-sea thermal contrasts (Ramstein et al., 1997, Zhang et al., 2007, Roe et al., 2016). The long-term global cooling during the Cenozoic (e.g. Cramer et al., 2009) could have induced the sea retreat by lowering the global sea level (Dupont-Nivet et al., 2007; Bosboom et al., 2014a, Bosboom et al., 2014b). Alternatively, the cooling may have caused aridification directly by weakening the hydrological cycle and the monsoons (Dupont-Nivet et al., 2007, Licht et al., 2014, Li et al., 2018a).

The Paleogene greenhouse period is key to understand the origin and mechanisms of Asian climate before significant Plateau uplift, sea retreat and global cooling had occurred. Early studies proposed that East Asia during this period was dominated by a subtropical arid belt with no monsoonal circulation (e.g. Guo et al., 2008). More recent studies show that the large-scale Asian atmospheric features were similar as today and that monsoons already existed during the Paleogene (Huber and Goldner, 2012; Licht et al., 2014, Licht et al., 2016; Quan et al., 2014, Caves et al., 2015, Roe et al., 2016). However, others suggest that these monsoons were only tropical and restricted to South Asia, while quasi-absent in East and Central Asia (Spicer et al., 2017, Li et al., 2018b).

Today, the low-level westerlies are the main source for atmospheric moisture in the region north of the Tibetan Plateau, which is shielded from the southerly 
monsoons. Stable isotopes reveal that the westerlies have dominated this region since at least the late Paleocene (Caves et al., 2015, Bougeois et al., 2018), when a proto-Tibetan Plateau already created an orographic barrier from the south (e.g. Molnar et al., 2010). During the Paleogene, the westerlies may have carried additional moisture from the proto-Paratethys Sea (Zhang et al., 2007, Roe et al., 2016, Bougeois et al., 2018), which extended from the Mediterranean up to western China at this time (e.g. Bosboom et al., 2014a, Bosboom et al., 2014b). The extent of this sea fluctuated with three progressively smaller sea incursions that are superimposed on a long-term retreat. These are now well-constrained in time and space by new paleogeographic analyses (Bosboom et al., 2014a, Bosboom et al., 2014b; Kaya et al., 2018). During highstands, the sea extended far into the Tarim Basin of western China, whereas during lowstands it retreated entirely beyond Tajikistan (Bosboom et al., 2014a, Bosboom et al., 2014b; Kaya et al., 2018). These incursions may have modulated the moisture carried by the westerlies and affected precipitation in western China (Bosboom et al., 2014a, Bosboom et al., 2014b; Bougeois et al., 2018).

The Xining Basin, located on the northeastern margin of the Tibetan Plateau (Fig. 1), provides an exceptional sedimentary record to understand Asian atmospheric circulation during the Paleogene. It contains quasi-continuous terrestrial mudrocks throughout the Cenozoic, which can be dated using magnetostratigraphy (e.g. Dai et al., 2006). Sedimentological and palynological studies show that these deposits reflect atmospheric moisture variations which are interpreted as the interplay between East Asian monsoons and westerlies (Abels et al., 2011, Bosboom et al., 2014c; Dupont-Nivet et al., 2007, Dupont-Nivet et al., 2008a). However, the Xining record has not been accurately dated and described before the late Eocene ( 40-34 Ma). Therefore, the climatic effects of the India-Asia collision, the earlier proto-Paratethys Sea incursions and the onset of global cooling, all occurring during the early to middle Eocene ( 56-40 Ma), remain unknown. 

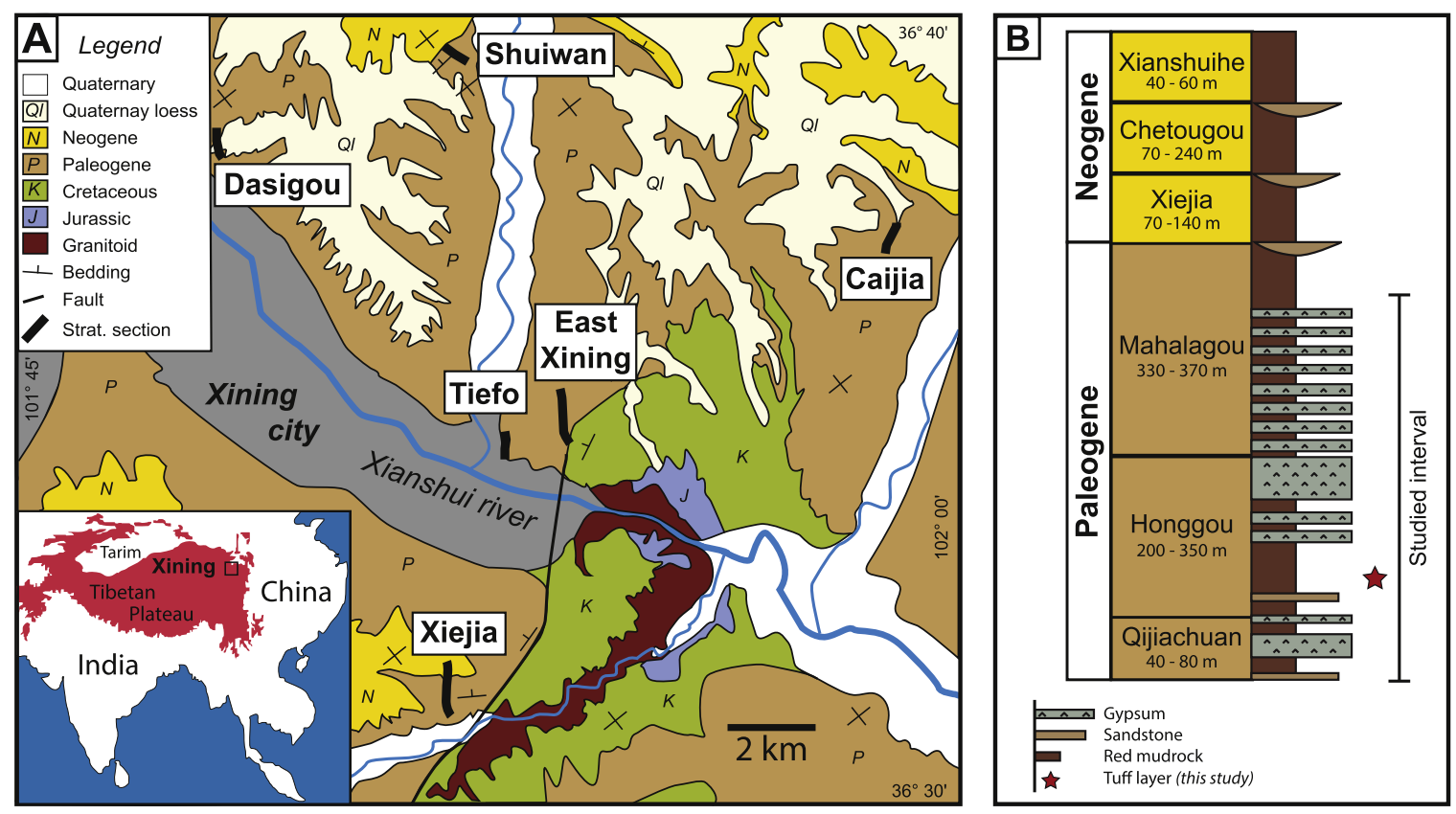

Fig. 1. (A) Regional geological map (QBGMR, 1985) showing the locations of the sections examined here and in previous studies. Inset map shows the location of the Xining Basin along the margin of the northeastern Tibetan Plateau. (B) Generalized stratigraphic column modified from Horton et al. (2004), listing formations, thicknesses and lithologies.

In this study, we extend the litho- and magnetostratigraphy of the upper Eocene Miocene deposits in the Xining Basin (Abels et al., 2011, Xiao et al., 2012, Bosboom et al., 2014c) to the lower Eocene where the magnetostratigraphy remained unreliable so far (Horton et al., 2004, Dai et al., 2006). We analyzed three laterally equivalent sections for magnetostratigraphy and complemented our correlations of the polarity zones with the radiometric age of a tuff layer. Furthermore, we interpret the evolution of atmospheric moisture and its driving mechanisms throughout the early Eocene to Oligocene epochs using our detailed lithostratigraphic descriptions and previous records from the Xining Basin.

\section{Geologic setting}

The Xining Basin forms the western part of the Cenozoic Longzhong Basin, which subsequently segmented into smaller sub-basins during deformation in the Miocene (Horton et al., 2004). The origin of the basin during the Paleogene is unclear and is hypothesized to be an extensional basin either due to thermal subsidence (Horton et al., 2004) or differential clockwise-rotation of crustal blocks (Zhang et al., 2016). Alternatively, the basin may have formed as a foreland basin of the Western Qinling Shan, a mountain range located $\sim 80 \mathrm{~km}$ to the south (Clark et al., 2010). 
The Paleogene strata of the Xining Basin are composed of red gypsiferous mudrocks and gypsum beds and include the Qiejiachuan, Honggou and Mahalagou Formations (Fig. 1B; QBGMR, 1985). The depositional environment is interpreted as a distal arid mudflat based on the lack of fluvial channels, the widespread occurrence of evaporites and the massive structure of the mudrocks resulting from subaerial reworking (Smoot and Lowenstein, 1991, Talbot et al., 1994, Dupont-Nivet et al., 2007, Abels et al., 2011). Provenance analysis shows that the fluvio-lacustrine deposits were mostly derived from distal highlands such as the Western Qinling Shan in the south and the Qilian Shan in the north (Zhang et al., 2016). The rest of the sediments were transported as eolian dust from reworked fluvial deposits and, to a minor extent, from the Qaidam Basin in the west (Licht et al., 2014, Licht et al., 2016).

Gypsum is formed by evaporating surface- or groundwater and accumulates to form gypsum beds when groundwater tables are sufficiently close to the surface to replenish the brine with the necessary solutes (Rosen, 1994, Dupont-Nivet et al., 2007, Abels et al., 2011). In well-drained settings with a deeper groundwater table, the evaporites are unlikely to be preserved (Rosen, 1994) and subaerially oxidized mudrocks accumulate instead (Dupont-Nivet et al., 2007, Abels et al., 2011). Basin-wide alternations between red mudrocks and saline lake evaporites therefore indicate changes in the groundwater table and are interpreted to reflect variations in atmospheric moisture in the catchment (Dupont-Nivet et al., 2007, Abels et al., 2011).

\section{Methods}

\subsection{Sections}

We resampled and analyzed at higher resolution the previously published East Xining $\left(36^{\circ} 34^{\prime} 50^{\prime \prime} \mathrm{N}, 101^{\circ} 53^{\prime} 42^{\prime \prime} \mathrm{E}\right)$ and Xiejia $\left(36^{\circ} 31^{\prime} 20^{\prime \prime} \mathrm{N}, 101^{\circ} 52^{\prime} 20^{\prime \prime}\right.$ E) sections (Horton et al., 2004, Dai et al., 2006) and added the newly sampled Caijia section $\left(36^{\circ} 36\right.$ ' $55^{\prime \prime} \mathrm{N}, 101^{\circ} 59^{\prime} 3^{\prime \prime}$ E). Stratigraphic thicknesses were measured using a Jacob's staff and detailed lithological logs were made in the field.

\section{2. $U-P b$ dating of a tuff}

A tuff layer from the Xiejia section was processed for $\mathrm{U}-\mathrm{Pb}$ radiometric dating. After crushing and grinding, the powder was separated using magnetic and heavy liquid separation. The zircon crystals were handpicked under a binocular microscope, mounted on a $25 \mathrm{~mm}$ ring of epoxy, grinded, polished and imaged 
using cathodoluminescence. In total, 31 zircon crystals were collected from the tuff sample and $\mathrm{U}-\mathrm{Pb}$ dating was conducted by in-situ laser ablation inductively coupled plasma mass spectrometry (LA-ICPMS) at Géosciences Rennes, France. Detailed analytical procedures and individual data are reported in the supplementary material. Additionally, three tuff samples were crushed and melted to make tablets for X-Ray Fluorescence (XRF) analysis to identify the chemical composition. The XRF analysis was performed using a PANalytical AXIOS Advanced at the German Research Center for Geosciences (GFZ), Potsdam, Germany.

\subsection{Magnetostratigraphy}

Paleomagnetic samples were collected at the sections with a resolution of $\sim 0.5$ to 1 meter where possible. Sampling was conducted using a portable electric drill and a compass mounted on an orientation stage. The paleomagnetic samples were thermally demagnetized with 10-15 temperature steps up to $680^{\circ} \mathrm{C}$. Samples from the Caijia section, and the lower $105 \mathrm{~m}$ of the Xiejia section were analyzed at Géosciences Rennes, France. Samples from the East Xining section and the upper $91 \mathrm{~m}$ of the Xiejia section were analyzed at the Paleomagnetic Laboratory 'Fort Hoofddijk' of the Faculty of Geosciences at Utrecht University, the Netherlands.

\section{Lithostratigraphy}

The measured sections (Fig. 2) are subdivided in formations following the classification of the Qinghai Bureau of Geology and Mineral Resources (QBGMR, 1985). In the following, these formations are described and interpreted in terms of depositional environment. Detailed logs are provided in the supplementary material (Fig. S1).

\subsection{Lower Qiejiachuan Formation}

\subsubsection{Description}

The lower part of the Qiejiachuan Formation ( $\sim 20 \mathrm{~m}$ thick) consists of massive red mudrocks (2.5YR 4/4) interbedded with a few massive sandstone beds. Occasionally, the mudrocks contain slickensides and centimeter-scale horizons of grey (5GY 5/1) mottling. The sandstone beds are up to a few decimeters thick, fine- to coarsegrained and laterally extensive. 


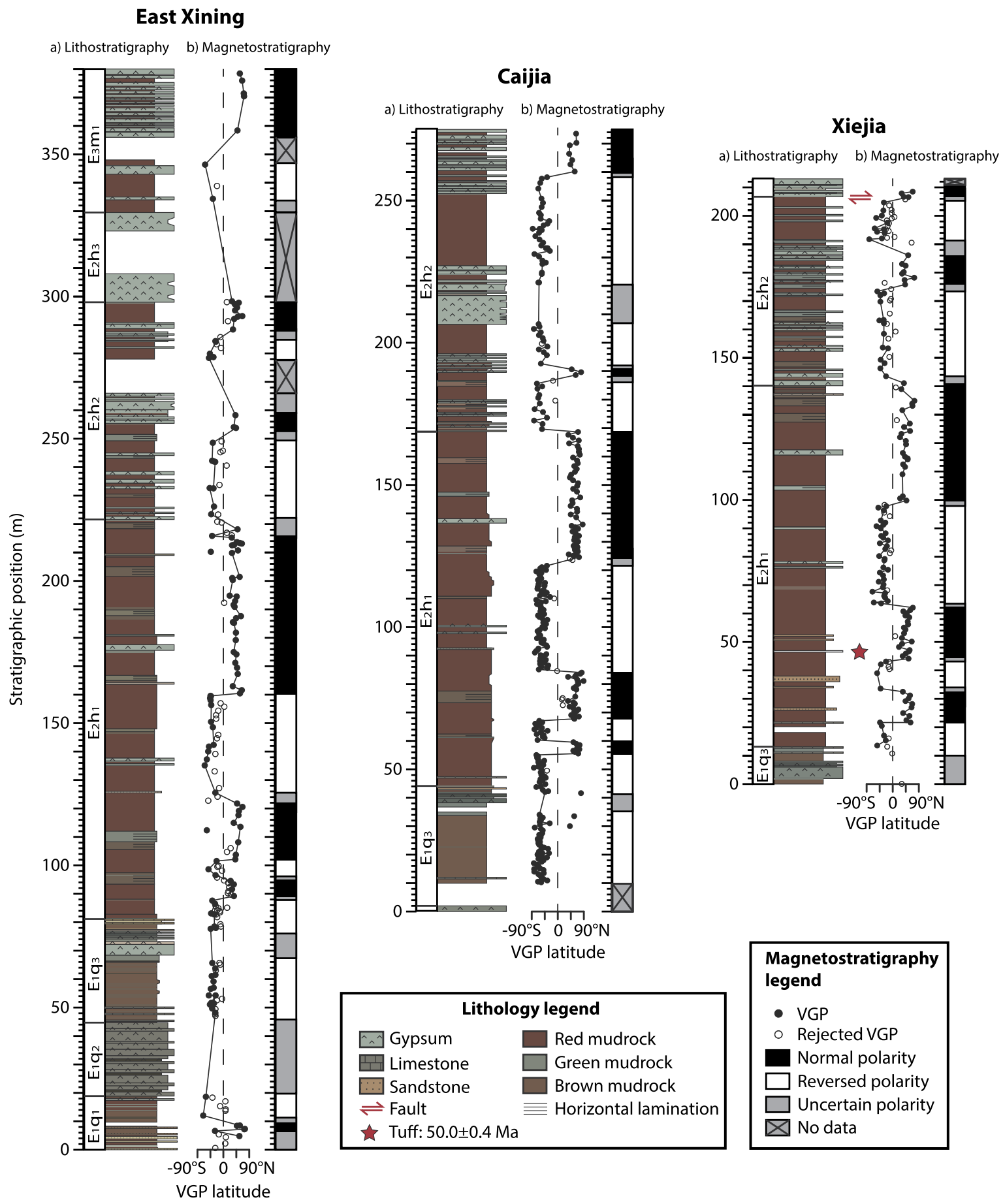

Fig. 2. The East Xining, Caijia and Xiejia sections showing (a) the lithostratigraphy and (b) the magnetostratigraphy with Virtual Geomagnetic Pole (VGP) latitudes and corresponding polarity zones.

\subsubsection{Interpretation}

The dominance of massive, oxidized mudrocks indicates deposition on a subaerially exposed mudflat (Smoot and Lowenstein, 1991, Dupont-Nivet et al., 2007, Abels et al., 
2011). The lateral extent and massive structure of the sandstone beds suggests deposition by unconfined fluvial flows (North and Davidson, 2012).

\subsection{Middle Qiejiachuan Formation}

\subsubsection{Description}

The middle Qiejiachuan Formation ( $\sim 30 \mathrm{~m}$ thick) is characterized by a laterally extensive package of gypsum beds. The beds are decimeters thick and alternate between light gray (10Y 5/1), indurated intervals and dark grey (N 3/1), less indurated, organicrich $($ TOC $=\sim 0.7-1.7 \%$ ) intervals (Fig. 3A). The gypsiferous beds are nodular, but reveal centimeter-scale horizontal lamination in fresh, unweathered outcrops (Fig. 3A).

\subsubsection{Interpretation}

The gypsum and horizontal lamination indicate deposition in a saline lake (Smoot and Lowenstein, 1991, Dupont-Nivet et al., 2007, Abels et al., 2011). The alternations between gypsiferous and carbonaceous beds may reflect fluctuating salinity and/or productivity (Potter et al., 2005).

\subsection{Upper Qiejiachuan Formation}

\subsubsection{Description}

The upper Qiejiachuan Formation ( $\sim 30 \mathrm{~m}$ thick) consists of massive mudrocks with a characteristic liver-brown color (5YR 4/2, Fig. 3B). The mudrocks contain specks of organic debris, abundant slickensides and are commonly interbedded with centimeterscale beds of coarse silt with ripple laminations. Centimeter-scale carbonate beds composed of micrite occur in the lower part. The top of the Qiejiachuan Formation consists of a $\sim 5$ meters-thick interval containing green (5GY 5/1) gypsiferous mudrocks and decimeter-scale beds of massive gypsum. The mudrocks are interbedded with centimeter-scale beds of micritic carbonate.

\subsubsection{Interpretation}

The lack of horizontal lamination and abundance of slickensides in the mudrocks indicate deposition on a subaerially exposed mudflat (Smoot and Lowenstein, 1991, Dupont-Nivet et al., 2007, Abels et al., 2011). The organic debris admixed with red regolith results in the characteristic liver-brown color (Potter et al., 2005). The rippled beds of coarse siltstones are interpreted to be deposited in episodic events of surface flow (North and Davidson, 2012). The carbonates may represent deposition in local, relatively freshwater ponds (Smoot and Lowenstein, 1991). The gypsum beds at 
the top indicate deposition in a saline lake (Smoot and Lowenstein, 1991, Abels et al., 2011).
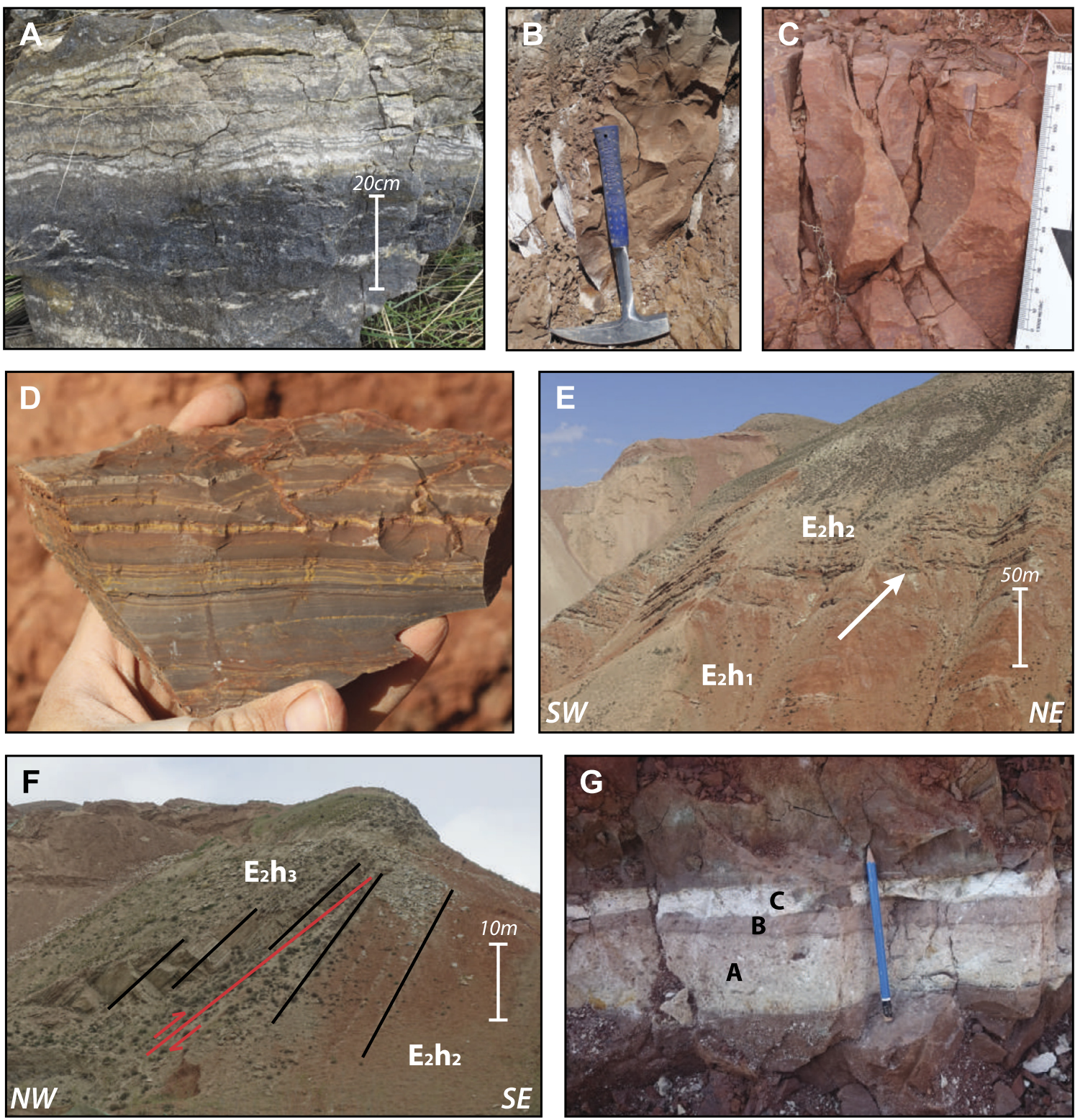

Fig. 3. Field photos showing: (A) an alternation between carbonaceous and gypsiferous beds in the middle Qiejiachuan Formation. Note the horizontal laminations in the upper part. (B) Massive liver-brown mudrock in the upper Qiejiachuan Formation. Hammer for scale. (C) Massive brick-red mudrock in the lower Honggou Formation showing mm-scale burrows. Scale-bar on the right. (D) Finely laminated brown mudrock in the lower Honggou Formation showing mudcracks and micrite laminae. (E) Overview of the Xiejia section showing the Honggou Formation. Arrow indicates the transition from the lower to middle Honggou Formation at the 140 meter-level. Scale-bar on the right (F) Overview of the top of the Xiejia section showing a fault at the base of the upper Honggou Formation. Scale-bar on the right. (G) A tuff bed in the Xiejia section at the 46.3 meter-level showing the three different layers that were geochemically analyzed ( $A, B$ and $C$ ). Pencil for scale. 


\subsection{Lower Honggou Formation}

4.4.1. Description

The lower Honggou Formation ( $\sim 130 \mathrm{~m}$ thick) is characterized by brick-red (2.5 YR 4/6) massive mudrocks (Fig. 3C). The mudrocks are commonly interbedded with centimeter-scale beds of rippled coarse siltstones. Rare cross-bedded sandstones occur as decimeter-scale beds in the lower part of the more proximal Xiejia section. The red mudrocks of the Honggou Formation contain abundant millimeterscale interstitial gypsum nodules. Millimeter-scale burrows, slickensides, blocky peds and grey (10GY 7/1) mottling are common, but millimeter-scale carbonate nodules are rare. The red mudrocks occasionally contain $<5$ meters-thick intervals of brown (5YR 4/2) mudrocks with millimeter-scale lamination (Fig. 3D). These intervals contain specks of organic debris, slickensides, desiccation cracks and centimeter-scale beds of micritic carbonate and gypsum. The red mudrocks are rarely interbedded with green (10GY 6/1), decimeter-scale beds of gypsum with either a nodular structure or centimeter-scale horizontal lamination.

\subsubsection{Interpretation}

The dominance of gypsiferous red mudrocks indicates deposition on a subaerially exposed arid mudflat (Smoot and Lowenstein, 1991, Dupont-Nivet et al., 2007, Abels et al., 2011), with occasional fluvial events evidenced by the coarse silt- and sandstone beds (North and Davidson, 2012). The laminated brown mudrock intervals are interpreted as lacustrine deposits. However, the observed desiccation cracks and slickensides suggest that these lakes were shallow and occasionally exposed to drying. The gypsum beds are interpreted as saline lake deposits (Smoot and Lowenstein, 1991, Abels et al., 2011).

\subsection{Middle Honggou Formation}

\subsubsection{Description}

A sudden increase in gypsum beds and mudrocks with fine horizontal laminations marks the transition (Fig. 3E) to the middle Honggou Formation ( $\sim 80 \mathrm{~m}$ thick). The laminated mudrocks range in color from brown (5YR 4/3) to green (10GY 6/1). Massive red mudrocks occur as well, but are less abundant than in the lower Honggou Formation. The gypsum beds are green (10GY 6/1), laminated or nodular, and range in thickness from decimeter- to meter-scale. The middle Honggou Formation can be traced 
regionally as a more gypsiferous interval. However, individual beds are laterally discontinuous between sections spaced up to $14.5 \mathrm{~km}$.

\subsubsection{Interpretation}

The massive red mudrocks, laminated mudrocks and gypsum beds are interpreted to be deposits of subaerially exposed mudflat, lake and saline lake environments respectively (Smoot and Lowenstein, 1991, Dupont-Nivet et al., 2007, Abels et al., 2011). The lateral discontinuity of the beds suggests that the lacustrine mudrocks and evaporites accumulated in local topographic depressions whereas oxidized mudflats formed on local highs. The nodular character of the gypsum beds is likely due to weathering because it is absent in fresh outcrops (Abels et al., 2011).

\subsection{Upper Honggou Formation}

\subsubsection{Description}

The upper Honggou Formation consists of a 10-30 meters-thick gypsum package containing decimeter-scale beds of massive to nodular gypsum as well as macrocrystalline gypsum and glauberite (Bosboom et al., 2014c). A minor fault observed at the base of the gypsum package in the Xiejia section may have resulted in a hiatus (Fig. 3F). Locally, the gypsum package can be replaced by fluvial sandstone beds, as observed in the Dasigou section, north of Xining (Fig. 1A; Bosboom et al., 2014c).

\subsubsection{Interpretation}

The thick accumulation of gypsum beds indicates prolonged deposition in a saline lake (Smoot and Lowenstein, 1991, Abels et al., 2011, Bosboom et al., 2014c). The beds containing euhedral macro-crystals suggest that the lake was perennial at times (Smoot and Lowenstein, 1991, Bosboom et al., 2014c). Although the thickness of the gypsum package varies, the upper Honggou Formation is characteristic and can be correlated across the basin (Horton et al., 2004).

\subsection{Lower Mahalagou Formation}

\subsubsection{Description}

The lower Mahalagou Formation ( $\sim 70 \mathrm{~m}$ thick) is characterized by meter-scale alternations between red mudrocks and gypsum beds that can be correlated between the studied sections (Dupont-Nivet et al., 2007, Abels et al., 2011, Bosboom et al., 2014c). The mudrocks have a massive structure, whereas the gypsum beds vary between a massive, laminated or nodular structure (Abels et al., 2011). An interval of reddish brown (5YR 4/3) mudrocks with a thickness of $\sim 20$ m occurs at the base. 


\subsubsection{Interpretation}

The Mahalagou Formation has been described extensively in previous studies and is interpreted as deposits of astronomically forced cycles between subaerial mudflats and saline lakes (Dupont-Nivet et al., 2007, Abels et al., 2011, Bosboom et al., 2014c).

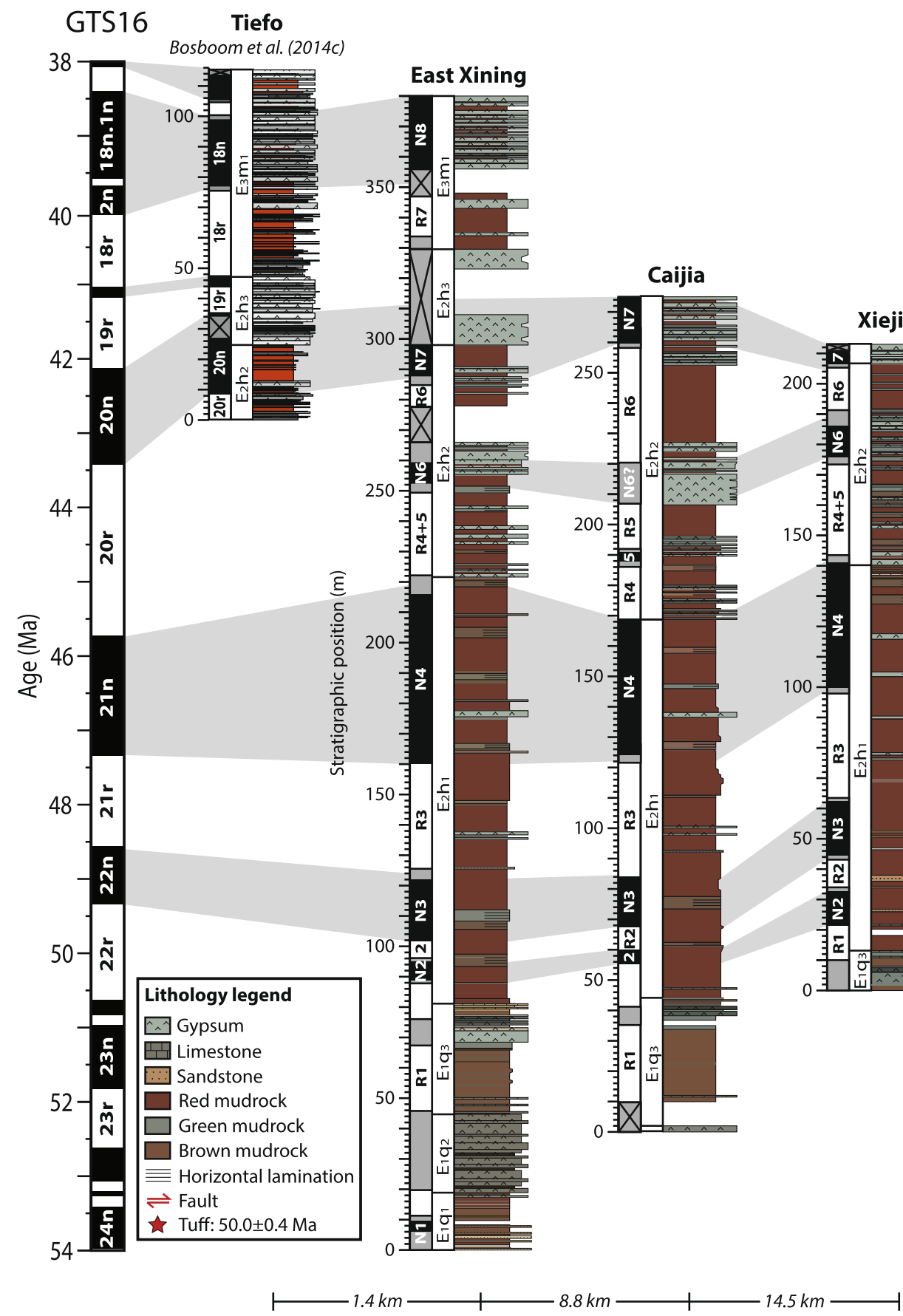

Depositional environment

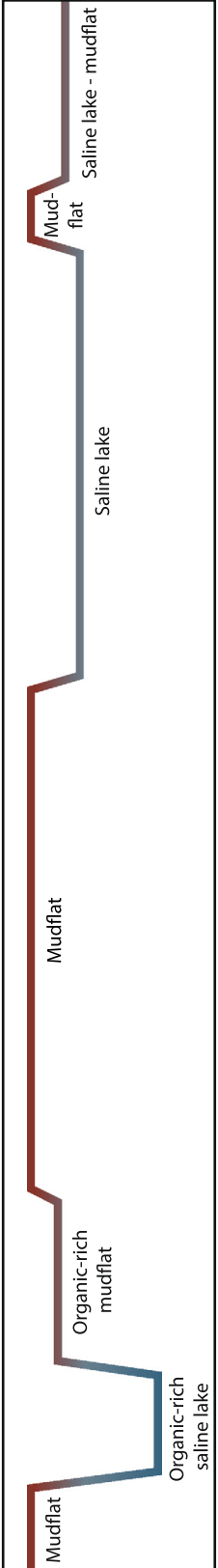

Dry $\longleftrightarrow$ Wet

Fig. 4. Magnetostratigraphic correlations between the three studied sections and the Tiefo section (Bosboom et al., 2014c). The chrons are correlated to the GTS16 (Ogg et al., 2016). Trends in the dominant depositional environment are shown on the right. 


\subsection{Summary}

Throughout the studied interval, we observe several trends in the depositional environments (Fig. 4). A decrease in organic matter indicates a long-term aridification in the record. Organic-rich deposits are abundant in the Qiejiachuan Formation, occur sporadically throughout the overlying Honggou Formation and disappear in the lower Mahalagou Formation along with carbonate beds (Bosboom et al., 2014c). Superimposed on this long-term drying we observe shorter term alternations between mudflat deposits and evaporites (Fig. 4). The middle Qiejiachuan Formation is dominated by saline lake deposits and is overlain by organic-rich mudflat deposits of the upper Qiejiachuan Formation and red mudrocks of the lower Honggou Formation. These mudflat deposits are followed by a shift to lacustrine mudrocks and evaporites in the overlying middle to upper Honggou Formation. This is followed by a $\sim 20$ meters-thick interval of mudflat deposits at the base of the overlying Mahalagou Formation, after which this formation is dominated by characteristic mudrock-evaporite cycles.

\section{0 $\mathrm{U}-\mathrm{Pb}$ radiometric dating of a volcanic tuff}

A volcanic tuff with a thickness of $12 \mathrm{~cm}$ was identified in the Xiejia section at the 46.3 meter-level (Fig. 3G) and is used to constrain the age of the deposits. The tuff is composed of three different layers and consists predominantly of vitreous matrix. The layers have similar chemical compositions (Table S1) and are classified, on an anhydrous basis, as trachyte (Fig. S2) according to the classification of Le Maitre et al. (1989). However, the relatively high concentration of volatiles (LOI $=\sim 8 \%$ ) indicates that this tuff may have been altered.

Of the 31 zircon crystals that were analyzed, 19 analyses plot in a concordant to subconcordant position (99 to 80\%, Fig. 5A), indicating the presence of a slight amount of common $\mathrm{Pb}$ in some of the zircon grains and/or a very small $\mathrm{Pb}$ loss. Their weighted average $206 \mathrm{~Pb} / 238 \mathrm{U}$ age (Fig. $5 \mathrm{~B}$ ) is well defined at $50.2 \pm 0.4 \mathrm{Ma}(\mathrm{MSWD}=1.9$ ). This mean age is equivalent within error with the lower intercept date of 50.0 $\pm 0.4 \mathrm{Ma}$ (Fig. $5 \mathrm{~A}$ ) if the discordia is forced to a $207 \mathrm{~Pb} / 206 \mathrm{~Pb}$ value of $0.839 \pm 0.01$ calculated (at $50 \pm$ $10 \mathrm{Ma}$ ) following the $\mathrm{Pb}$ evolution model of Stacey and Kramers (1975). This is also similar to the Tuffzirc age (Ludwig and Mundil, 2002) of $50.15+0.65 /-0.45 \mathrm{Ma}$. We therefore conclude that this tuff was deposited at $50.0 \pm 0.4 \mathrm{Ma}$. 

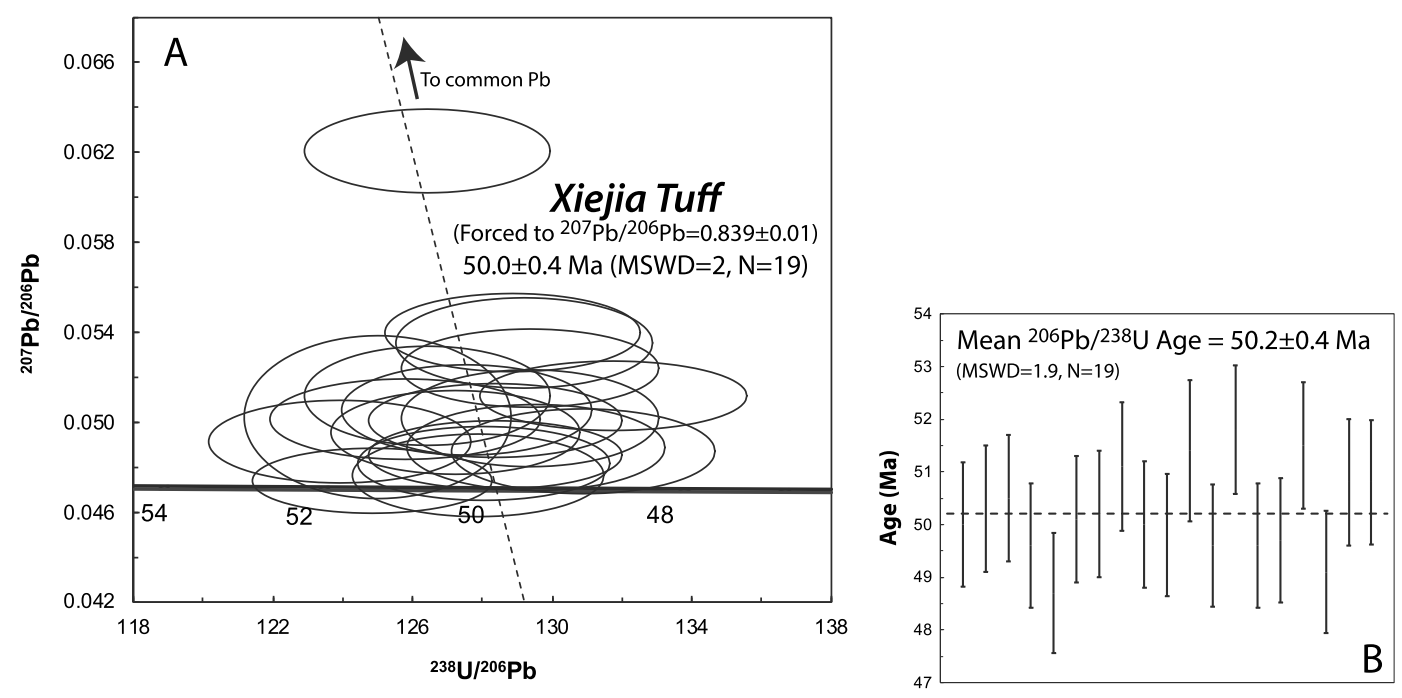

Fig. 5. (A) Tera-Wasserburg diagram for the youngest group of zircons. (B) Weighted average 206Pb/238U Age for the same 19 zircon grains. All ellipses and apparent $206 \mathrm{~Pb} / 238 \mathrm{U}$ ages are plotted at $2 \sigma$.

The remaining 12 crystals produced apparent ages ranging from 237 to $2450 \mathrm{Ma}$ and are interpreted as xenocrystic in origin. The Eocene volcanic belt throughout the northern Qiangtang terrane provides a possible source for the tuff, since multiple ages reported here fit well within the error range of our tuff sample (Chapman and Kapp, 2017).

\section{Magnetostratigraphy}

Paleomagnetic analysis is used to identify reversals and further constrain the age of the deposits.

\subsection{Thermal demagnetization}

Demagnetization of the red mudrock samples up to $200-300{ }^{\circ} \mathrm{C}$ resulted in the removal of a secondary normal overprint and is followed by a linear decay towards the origin (Fig. S3). A drop in magnetization is observed between $550-680{ }^{\circ} \mathrm{C}$ indicating a combination of hematite and magnetite as the dominant ferromagnetic carriers (Fig. S3). Samples from the gypsum beds have a lower magnetization and showed erratic directions that could not be interpreted. The magnetic behavior is similar as observed in previous studies in the Xining Basin (Dai et al., 2006, Dupont-Nivet et al., 2007, DupontNivet et al., 2008b; Abels et al., 2011, Xiao et al., 2012, Bosboom et al., 2014c).

\subsection{ChRM directions}

Characteristic remanent magnetization (ChRM) directions of the samples were calculated by eigenvector principal component analysis (Kirschvink, 1980) on at least 
four temperature steps showing a linear decay between $300-600^{\circ} \mathrm{C}$. Maximum angular deviations (MAD) were estimated for all calculated ChRM directions. All samples have a MAD $<30^{\circ}$ and most are $<10^{\circ}$.

Virtual geomagnetic poles (VGPs) were calculated from the ChRM directions and the VGP latitudes are shown in Fig. 2 and Fig. S1. The VGPs show two clusters of either normal (positive latitude) or reversed (negative latitude) polarity. Samples with a VGP of more than $45^{\circ}$ from the mean normal or reversed VGP are considered outliers and removed from further analysis (open symbols in Fig. 2 and Fig. S1, red symbols in Fig. S4).

The means for both the normal and reversed ChRM directions were calculated for each section (Fig. S4) using Fisher statistics (Fisher, 1953). Reversals tests (McFadden and McElhinny, 1990) performed on the mean directions of the sections are negative indicating that the angle between the mean normal and reversed polarities is larger than the critical angle. These negative reversals tests are due to an unresolved normal overprint as observed in previous studies in the Xining Basin (Dupont-Nivet et al., 2008b, Xiao et al., 2012, Bosboom et al., 2014c). This is especially evident in the Xiejia and East Xining sections (Fig. S4), which are more tilted (dip of $\sim 50^{\circ}$ ) compared to the Caijia section (dip of $\sim 7^{\circ}$ ). The normal overprint would preclude the use of these datasets for tectonic rotation analysis but it does not affect the reliability of the magnetostratigraphy used in this study as discussed further below.

\subsection{Correlation to the GTS}

Polarity zones are identified by at least two successive samples of the same polarity and are labeled N1 to N8 and R1 to R7 (Fig. 4). The magnetostratigraphy is laterally similar and can be readily correlated between the studied sections. However, normal zone N5 is only observed in the Caijia section. This zone with a thickness of only 2-4 $\mathrm{m}$ is probably missed in the other sections due to a lower resolution of reliable VGP's. Zone N6 is lacking in the Caijia section because no magnetic signal is recorded in the gypsum beds of this interval.

In the following, the polarity zones are correlated to chrons (Fig. 4) in the geological timescale (GTS16, Ogg et al., 2016). The tuff, located at the base of normal polarity zone N3, provides a tie point for our correlation. The only normal chron with a basal age near $50 \pm 0.4 \mathrm{Ma}$ is C22n, which has a basal age of $49.3 \mathrm{Ma}$ in the GTS16, but was recently tuned to $49.7 \mathrm{Ma}$ (Westerhold et al., 2017). The latter age fits well within the error range 
of the tuff. Zone N3 is therefore correlated to C22n. The overlying zones R3 and N4 are then correlated to $\mathrm{C} 21 \mathrm{r}$ and $\mathrm{C} 21 \mathrm{n}$ respectively. $\mathrm{C} 21 \mathrm{n}$ is followed by a relatively long reversed and a long normal chron (C20r and C20n) in the timescale that were both identified at the base of the Tiefo section (Bosboom et al., 2014c). It follows that polarity zone N7 can be correlated to C20n by using the characteristic gypsum package of the upper Honggou Formation as a marker bed. Zones R7 and N8 in the East Xining section are subsequently correlated to $\mathrm{C} 18 \mathrm{r}$ and $\mathrm{C} 18 \mathrm{n}$ by using the gypsum cycles of the Mahalagou Formation as marker beds. Following the above, zones R4 to R6 are unequivocally correlated to C20r. The resulting age model shows stable accumulation rates of $\sim 3 \mathrm{~cm} / \mathrm{kyr}$ in the Honggou Formation (Fig. S5), which is similar to rates observed in the overlying sections (Abels et al., 2011, Xiao et al., 2012; Bosboom et al., 2014c). This suggests an absence of major hiatuses and further supports our correlation. However, the short normal zones N5 and N6 (with thicknesses of 5 to $10 \mathrm{~m}$ ) remain uncorrelated in our interpretation. No such zones are observed in C20r of the geological timescale. Zone N2, located just below N3, is uncorrelated as well because a correlation to $\mathrm{C} 23 \mathrm{n}$ would result in an unusually low accumulation rate of $\sim 0.6 \mathrm{~cm} / \mathrm{kyr}$ in both $\mathrm{R} 2$ (when correlated to C22r) and N2 (when correlated to C23n). To our knowledge, short normal chrons that could relate to N2, N5 and N6 have not been reported in any published marine or terrestrial records of this interval (e.g. Fig. 6 in Turtù et al., 2017 and references therein). Bouligand et al. (2006) record nine cryptochrons in C20r and three in C22r based on stacked marine magnetic anomaly profiles. Most of these cryptochrons have a short duration of less than 8 kyrs, but three have relatively long durations of 12 to 14 kyrs (C20r-5, C20r-6 and C22r-1). These three longer cryptochrons could fit with the stratigraphic positions of the short normal zones in the Xining Basin. However, this would imply anomalously high accumulation rates of at least $\sim 35 \mathrm{~cm} / \mathrm{kyr}$ for these cryptochrons to be recorded in the observed $>5$ meters-thick normal zones. Therefore, a more probable hypothesis is that these zones result from secondary magnetizations occurring in stratigraphic intervals prone to remagnetization. However, we found no clear differences in lithologies (Fig. 2, S1), magnetic behavior (Fig. S3) and ChRM directions (Fig. S4) compared to the other polarity zones. Nevertheless, the pervasive secondary normal overprint evidenced by the failed reversals tests suggests that some stratigraphic intervals may have been overprinted. 
The age of the Qiejiachuan Formation cannot be constrained due to the low resolution of reliable VGP latitudes in the gypsum interval of the middle Qiejiachuan Formation. This hinders the record of the expected polarity zones below the radiometric age of the tuff $(50.0 \pm 0.4 \mathrm{Ma})$ and thus prevents a reliable downward extension of the magnetostratigraphic correlation.

\section{Discussion}

Our magnetostratigraphic correlations indicate that the Honggou Formation spans from $\sim 50 \mathrm{Ma}(\mathrm{C} 22 \mathrm{r})$ to $\sim 41 \mathrm{Ma}$ (top of $\mathrm{C} 19 \mathrm{n}$ ). This extends the dated stratigraphic record to cover the early Eocene to Oligocene epochs (Fig. 6; Abels et al., 2011, Xiao et al., 2012, Bosboom et al., 2014c). Our age model agrees broadly with the preferred correlations reported in Dai et al. (2006), except for two notable differences: (1) our record shows that N22 in Dai et al. (2006) consists of two separate normal zones. The upper of these is correlated to C22n, which is now further constrained by the age of the tuff. The lower is interpreted here as a remagnetized normal zone. (2) N23 in Dai et al. (2006) is not observed in this study and is likely a result of remagnetized samples from this gypsiferous interval. Therefore, the previously proposed correlation of the base of the Xiejia section to $\sim 52 \mathrm{Ma}$ (Dai et al., 2006) is revised by our results to $\sim 50 \mathrm{Ma}$. Our paleo-environmental record shows a long-term drying trend from $\sim 50$ to $40 \mathrm{Ma}$ (Fig. 4, Fig. 6), which is corroborated by previous rock magnetic analyses in the basin (Fang et al., 2015). This drying trend persists in the overlying deposits, where the disappearance of organic-rich deposits and carbonate beds in the Mahalagou Formation is synchronous with an aridification step in the pollen record between 40.6 and $39.4 \mathrm{Ma}$ (Bosboom et al., 2014c). Successive aridification steps are then recorded by a decrease in gypsum beds at $\sim 37 \mathrm{Ma}$ ('Step 1', Abels et al., 2011), an increase in accumulation rate at 235 Ma ('Step' 2, Abels et al., 2011) and the final disappearance of saline lakes at the Eocene-Oligocene Transition (EOT; Dupont-Nivet et al., 2007). This long-term aridification of the Xining Basin has been linked to Tibetan Plateau uplift (Li et al., 2018a), long-term proto-Paratethys Sea retreat (Dupont-Nivet et al., 2007, Abels et al., 2011; Bosboom et al., 2014a, Bosboom et al., 2014b) and global cooling (Dupont-Nivet et al., 2007, Abels et al., 2011, Bosboom et al., 2014c, Fang et al., 2015, Li et al., 2018a) and is likely the result of a combination of these mechanisms. 


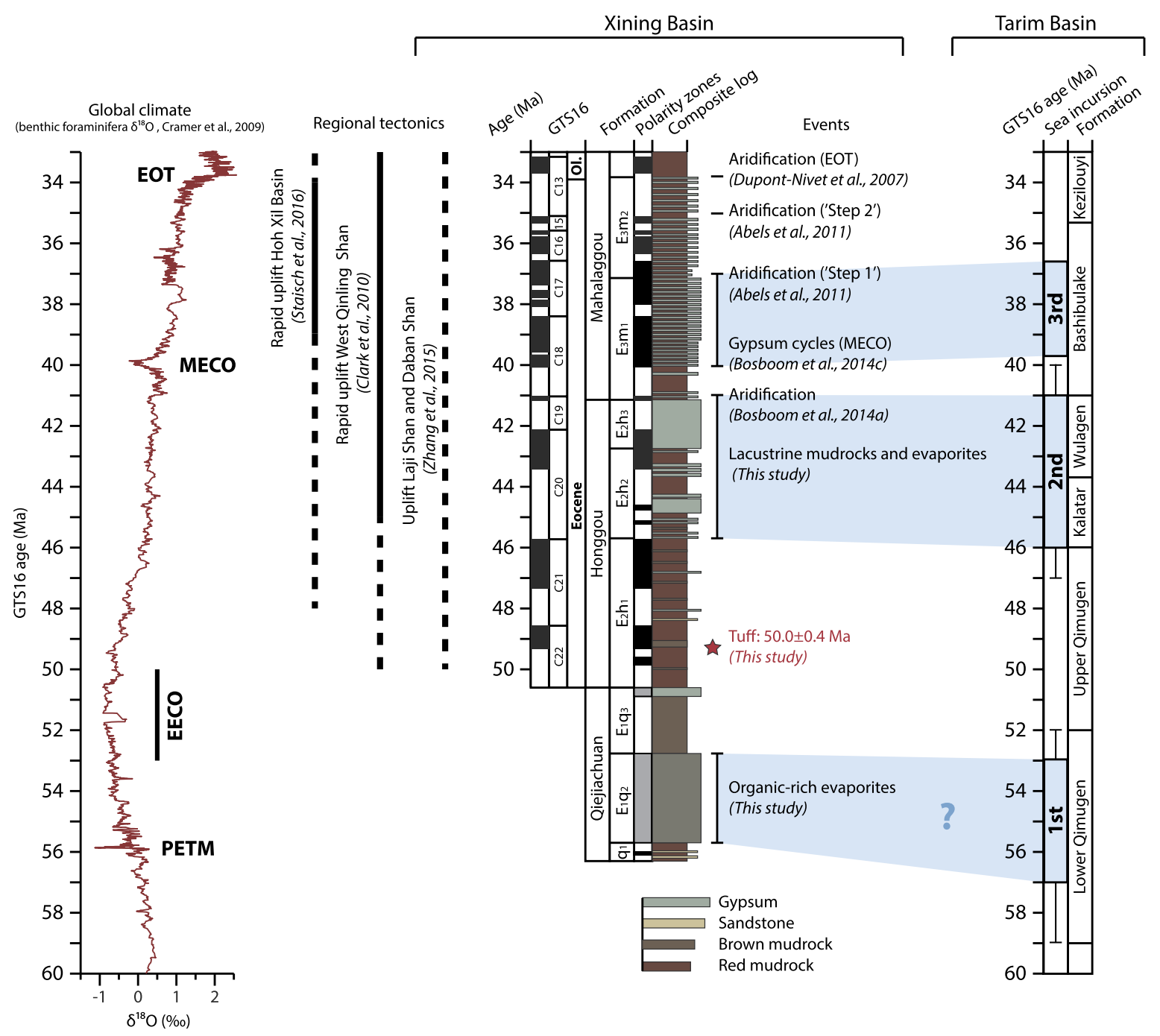

Fig. 6. Composite lithostratigraphy of the East Xining, Tiefo (Bosboom et al., 2014c) and Shuiwan (Abels et al., 2011) sections. Global climate is represented by a 9-point moving average through the benthic foraminifera $\delta 180$ record of Cramer et al. (2009). Regional tectonic events and climatic events observed in the basin are indicated, as well as the proto-Paratethys Sea incursions observed in the Tarim Basin (Kaya et al., 2018).

Within this long-term 50-34 Ma drying trend, we observed shorter term alternations between mudflat and saline lake deposits (Fig. 6). Based on previous interpretations in the Xining Basin, we interpret these alternations to represent fluctuations in atmospheric moisture (Dupont-Nivet et al., 2007, Abels et al., 2011). A first wet phase is expressed in the middle Qiejiachuan Formation by organic-rich evaporites. The age can only be approximated to late Paleocene-early Eocene based on existing pollen, ostracod and charophyte assemblages (Horton et al., 2004 and references therein) and by extending the average accumulation rate of the overlying deposits downwards. A second wet phase, is recognized as a shift to more 
lacustrine mudrocks and evaporites in the middle to upper Honggou Formation. This phase can now be dated from $\sim 46$ Ma (top C21n) to the top of the upper Honggou evaporites as previously recognized at $\sim 41$ Ma (base of C18r; Bosboom et al., 2014a, Bosboom et al., 2014c). A third wet phase is observed to start at $\sim 40 \mathrm{Ma}$ (base C18n) with the onset of regular gypsum/mudrock cycles (Bosboom et al., 2014c) and end at a decrease in gypsum beds at 37 Ma (top C17n.1n, 'Step 1' in Abels et al., 2011). This last phase was likely less intense, more fluctuating and drier, as indicated by the absence of organic-rich layers or carbonate beds and the presence of numerous interfingering layers of red mudrocks. These saline lake phases are laterally continuous throughout the basin suggesting an external control rather than an expression of autogenic basin infill. To identify potential driving mechanisms for the observed moisture fluctuations, we review constraints on tectonic uplift, proto-Paratethys Sea incursions and global climate trends (Fig. 6).

The influence of local tectonic uplift on moisture variations is considered unlikely because accumulation rates are continuously low ( $\sim 3 \mathrm{~cm} / \mathrm{kyr}$, Fig. S5), no coarsening trends are observed and exhumation of the local mountain ranges (the Laji Shan and Daban Shan) occurred mainly in the Miocene (e.g. Lease et al., 2011). A loosely dated Eocene phase of exhumation is observed bordering the Xining Basin (Zhang et al., 2015) and more regionally in both the northern Tibetan Plateau (Western Qinling Shan; Clark et al., 2010) and the central Plateau (Hoh Xil Basin; Staisch et al., 2016). Although this Eocene growth of the Tibetan Plateau may explain the long-term drying trend (Li et al., 2018a), the observed shorter term shifts appear too abrupt (Fig. 3G) to be caused by the slow tectonic uplift of the Plateau. Furthermore, the continuously growing Plateau cannot explain the episodic occurrence of wetter lithofacies which are separated by intervals of dry mudflats.

Previous studies have temporally linked the Xining aridification steps to the stepwise retreating proto-Paratethys Sea (Dupont-Nivet et al., 2007, Abels et al., 2011; Bosboom et al., 2014a, Bosboom et al., 2014b). During the Paleogene, the long-term sea retreat is superimposed by three progressively smaller incursions each dated by bio- and magnetostratigraphic studies (Fig. 6, Fig. 7; Bosboom et al., 2014a, Bosboom et al., 2014b; Kaya et al., 2018). A recent reappraisal of these incursions in the Tarim Basin (Kaya et al., 2018) provides the following age constraints. The first and most extensive incursion lasted from $\sim 59-57 \mathrm{Ma}$ to $\sim 53-52 \mathrm{Ma}$; the second incursion from $\sim 47-46 \mathrm{Ma}$ 
to $~ 41-40 \mathrm{Ma}$ and the third and smallest sea incursion is more precisely dated from 39.8 Ma to 36.7 Ma (Fig. 6, Fig. 7). These incursions fit well with the three wetter intervals recognized in the Xining Basin (Fig. 6). Our study therefore shows a temporal link between the proto-Paratethys highstands and increased moisture in the Xining Basin.

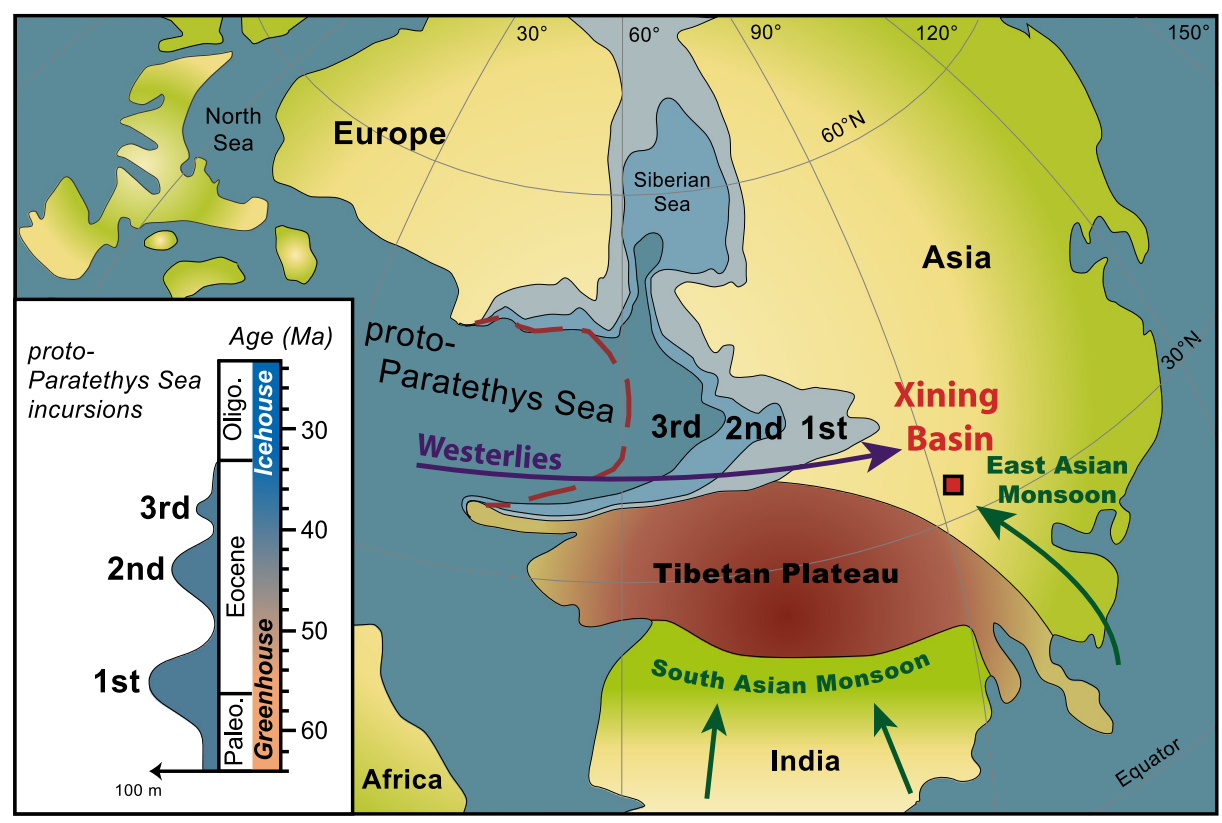

Fig. 7. Generalized paleogeography of Eurasia during the Paleogene, modified from Bosboom et al. (2014a). The maximum spatial extent of the three proto-Paratethys Sea incursions are indicated on the map and in time on the left. The approximate extent of the regressions in between the incursions is indicated with a red dashed line. Atmospheric moisture sources are shown with arrows.

This moisture could have been derived either from the winter-time westerlies or the summer monsoon (Fig. 7). Climate models suggest that Asian summer monsoons may be weakened by the proto-Paratethys Sea due to reduced land-sea contrasts (Ramstein et al., 1997, Zhang et al., 2007, Roe et al., 2016). Other studies indicate that the sea was too shallow to affect monsoonal circulation, even during highstands (Licht et al., 2014, Bougeois et al., 2018). Either way, it seems unlikely that an extensive protoParatethys Sea was associated with increased monsoonal activity. Instead, the highstands would increase the amount of water available for evaporation along the westerly pathway (Bosboom et al., 2014a, Bosboom et al., 2014b; Bougeois et al., 2018). This would result in more winter precipitation and provides an explanation for the wetter lithofacies in Xining coeval with the sea incursions. This interpretation is in line with previous studies showing that Central Asian climate and coeval deposits were 
strongly influenced by the westerlies at this time (Caves et al., 2015, Bougeois et al., 2018).

Previous studies also suggested that global climate might have played a role in the Xining record (Fig. 6). Temperatures generally decreased during the studied interval but are superimposed by hyperthermal events and periods of incipient ice sheet formation (Fig. 6; e.g. Cramer et al., 2009). The onset of obliquity cycles after $\sim 40$ Ma has been associated with ice sheet dynamics after the MECO (Middle Eocene Climatic Optimum, Abels et al., 2011, Bosboom et al., 2014c) and the aridification at 34 Ma has been linked to global cooling at the EOT (Dupont-Nivet et al., 2007). The latter may have resulted from either a weaker hydrological cycle in a colder climate (Licht et al., 2014, Li et al., 2018a), or from the proto-Paratethys Sea retreat induced by the growth of the Antarctic ice sheet (Dupont-Nivet et al., 2007, Bosboom et al., 2014a). However, the short-term moisture shifts observed in this study do not correspond with global climate events (Fig. 6). Instead, they systematically fit with the proto-Paratethys Sea incursions and retreats, some of which are thought to be driven by tectonics and others by eustasy (Bosboom et al., 2014a, Bosboom et al., 2014b; Kaya et al., 2018). Therefore, we suggest that the sea itself was a direct driver of precipitation in the region via the westerlies.

\section{Conclusion}

Our results extend the Xining record down to the early Eocene $(\sim 50 \mathrm{Ma})$ by using magnetostratigraphy and tuff dating. This extended time frame shows a long-term drying trend in the lithostratigraphy with superimposed wetter periods that correlate in time with highstands of the proto-Paratethys Sea. These correlations suggest that moisture in the region was governed by the westerlies and modulated by

the Paleogene sea incursions. The overall aridification of the Xining Basin may be explained by the long-term retreat of the proto-Paratethys Sea as well as the effects of the Tibetan uplift and global cooling.

Our results stress that, beyond the traditionally invoked Tibetan uplift and global climate as drivers of Asian climate, sea-driven moisture fluctuations should be taken into account as well. These results might influence both the assessment of model and proxy data constraining Eurasian weathering and dust production (Licht et al., 2016) as well as paleobiogeographic reconstructions (e.g. Favre et al., 2015). Building upon these results, a better understanding of the interplay between the westerlies and monsoons at 
tectonic, orbital and seasonal timescales may be obtained by further work focused on the identification and quantification of the moisture sources in the Xining Basin as well as in other regional records.

\section{Acknowledgments}

This work was funded by the ERC consolidator grant MAGIC 649081 to GDN. We thank Antje Musiol for support in the lab and we are grateful to Tianyuan Chen, Xiaohui $\mathrm{Wu}$, Zhipeng $\mathrm{Wu}$ and Liu Xiang-Jun for field assistance and logistical support. We thank John

Bershaw and two anonymous reviewers for their valuable comments.

\section{References}

H.A. Abels, G. Dupont-Nivet, G. Xiao, R. Bosboom, W. Krijgsman; Step-wise change of Asian interior climate preceding the Eocene-Oligocene Transition (EOT), Palaeogeogr. $\quad$ Palaeoclimatol. $\quad$ Palaeoecol., 299 (3) (2011), $\quad$ pp. 399412, 10.1016/j.palaeo.2010.11.028

R. Bosboom, G. Dupont_Nivet, A. Grothe, H. Brinkhuis, G. Villa, O. Mandic, M. Stoica, W. H uang, W. Yang, Z. Guo, W. Krijgsman; Linking Tarim Basin sea retreat (west China) and Asian aridification in the late Eocene, Basin Res., 26 (5) (2014), pp. 621-640, 10.1111/bre.12054

R. Bosboom, G. Dupont_Nivet, A. Grothe, H. Brinkhuis, G. Villa, O. Mandic, M. Stoica, T. Ko uwenhoven, W. Huang, W. Yang, Z. GuoTiming, cause and impact of the late Eocene stepwise sea retreat from the Tarim Basin (west China) Palaeogeogr. Palaeoclimatol. Palaeoecol., 403 (2014), pp. 101118, 10.1016/j.palaeo.2014.03.035

R.E. Bosboom, H.A. Abels, C. Hoorn, B.C. van den Berg, Z. Guo, G. DupontNivetAridification in continental Asia after the Middle Eocene Climatic Optimum (MECO); Earth Planet. Sci. Lett., 389 (2014), pp. 3442, 10.1016/j.epsl.2013.12.014

L. Bougeois, G. Dupont-Nivet, M. de Rafélis, J.C. Tindall, J.N. Proust, G.J. Reichart, L.J. de Nooijer, Z. Guo, C. OrmukovAsian monsoons and aridification response to Paleogene sea retreat and Neogene westerly shielding indicated by seasonality in Paratethys oysters; Earth Planet. Sci. Lett., 485 (2018), pp. 99110, 10.1016/j.epsl.2017.12.036

C. Bouligand, J. Dyment, Y. Gallet, G. HulotGeomagnetic field variations between chrons 33r and 19r (83-41 Ma) from sea-surface magnetic anomaly profiles; Earth Planet. Sci. Lett., 250 (3) (2006), pp. 541-560, 10.1016/j.epsl.2006.06.051

J.K. Caves, M.J. Winnick, S.A. Graham, D.J. Sjostrom, A. Mulch, C.P. ChamberlainRole of the westerlies in Central Asia climate over the Cenozoic; Earth Planet. Sci. Lett., 428 (2015), pp. 33-43, 10.1016/j.epsl.2015.07.023

J.B. Chapman, P. KappTibetan magmatism database; Geochem. Geophys. Geosyst (2017), 10.1002/2017GC007217 
M.K. Clark, K.A. Farley, D. Zheng, Z. Wang, A.R. DuvallEarly Cenozoic faulting of the northern Tibetan Plateau margin from apatite (U-Th)/He ages; Earth Planet. Sci. Lett., 296 (1) (2010), pp. 78-88, 10.1016/j.epsl.2010.04.051

B.S. Cramer, J.R. Toggweiler, J.D. Wright, M.E. Katz, K.G. MillerOcean overturning since the Late Cretaceous: inferences from a new benthic foraminiferal isotope compilation; Paleoceanography, 24 (4) (2009), 10.1029/2008PA001683

S. Dai, X. Fang, G. DupontNivet, C. Song, J. Gao, W. Krijgsman, C. Langereis, W. ZhangMagnetostratigraphy of Cenozoic sediments from the Xining Basin: tectonic implications for the northeastern Tibetan Plateau; J. Geophys. Res., Solid Earth, 111 (B11) (2006), 10.1029/2005JB004187

G. Dupont-Nivet, W. Krijgsman, C.G. Langereis, H.A. Abels, S. Dai, X. FangTibetan plateau aridification linked to global cooling at the Eocene-Oligocene transition; Nature, 445 (7128) (2007), pp. 635-638

G. Dupont-Nivet, C. Hoorn, M. KonertTibetan uplift prior to the Eocene-Oligocene climate transition: evidence from pollen analysis of the Xining Basin; Geology, 36 (12) (2008), pp. 987-990, 10.1130/G25063A.1

G. Dupont-Nivet, S. Dai, X. Fang, W. Krijgsman, V. Erens, M. Reitsma, C. LangereisTiming and distribution of tectonic rotations in the northeastern Tibetan Plateau; Investigations into the Tectonics of the Tibetan Plateau, Geological Society of America, Special Papers, vol. 444 (2008), pp. 73-87

X. Fang, J. Zan, E. Appel, Y. Lu, C. Song, S. Dai, S. TuoAn Eocene-Miocene continuous rock magnetic record from the sediments in the Xining Basin, NW China: indication for Cenozoic persistent drying driven by global cooling and Tibetan Plateau uplift; Geophys. J. Int., 201 (1) (2015), pp. 78-89, 10.1093/gji/ggv002

A. Favre, M. Päckert, S.U. Pauls, S.C. Jähnig, D. Uhl, I. Michalak, A.N. Muellner-RiehlThe role of the uplift of the Qinghai-Tibetan Plateau for the evolution of Tibetan biotas; Biol. Rev., 90 (1) (2015), pp. 236-253, 10.1111/brv.12107

R. FisherDispersion on a sphere; Proc. R. Soc. Lond. A, Math. Phys. Eng. Sci., 217 (1130) (1953, May), pp. 295-305, 10.1098/rspa.1953.0064

Z.T. Guo, B. Sun, Z.S. Zhang, S.Z. Peng, G.Q. Xiao, J.Y. Ge, Q.Z. Hao, Y.S. Qiao, M.Y. Liang, J.F. Liu, Q.Z. Yin, J. WeiA major reorganization of Asian climate by the early Miocene; Clim. Past, 4 (3) (2008), pp. 153-174, 10.5194/cp-4-153-2008

B.K. Horton, G. Dupont-Nivet, J. Zhou, G.L. Waanders, R.F. Butler, J. WangMesozoicCenozoic evolution of the Xining-Minhe and Dangchang basins, northeastern Tibetan Plateau: magnetostratigraphic and biostratigraphic results; J. Geophys. Res., Solid Earth, 109 (B4) (2004), 10.1029/2003JB002913

M. Huber, A. GoldnerEocene monsoons; J. Asian Earth Sci., 44 (2012), pp. 323, 10.1016/j.jseaes.2011.09.014

M.Y. Kaya, G. Dupont-Nivet, J-

N. Proust, P. Roperch, L. Bougeois, N. Meijer, J. Frieling, C. Fioroni, S.Ö. Altiner, E. Vardar, M. Stoica, M. Mamtimin, Z. GuoPaleogene evolution and demise of the proto-Paratethys Sea in Central Asia (Tarim and Tajik basins): role of intensified tectonic activity at $~ 41 \mathrm{Ma}$; Basin Res (2018), 10.1111/bre.12330

J.L. KirschvinkThe least-squares line and plane and the analysis of palaeomagnetic data; Geophys. J. Int., 62 (3) (1980), pp. 699-718, 10.1111/j.1365246X.1980.tb02601.x 
R.O. Lease, D.W. Burbank, M.K. Clark, K.A. Farley, D. Zheng, H. ZhangMiddle Miocene reorganization of deformation along the northeastern Tibetan Plateau; Geology, 39 (4) (2011), pp. 359-362, 10.1130/G31356.1

R.W. Le Maitre, P. Bateman, A. Dudek, J. Keller, J. Lameyre, M. Le Bas, P. Sabine, R. Schmid, H. Sorensen, A. Streckeisen, A.R. Woolley, B. ZanettinA Classification of Igneous Rocks and Glossary of Terms: Recommendations of the International Union of Geological Sciences, Subcommission on the Systematics of Igneous Rocks; Blackwell, Oxford (1989); 193 pp

X. Li, R. Zhang, Z. Zhang, Q. YanWhat enhanced the aridity in Eocene Asian inland: global cooling or early Tibetan Plateau uplift?; Palaeogeogr. Palaeoclimatol. Palaeoecol., 510 (2017), pp. 6-14, 10.1016/j.palaeo.2017.10.029

X. Li, R. Zhang, Z. Zhang, Q. YanDo climate simulations support the existence of East Asian monsoon climate in the Late Eocene?; Palaeogeogr. Palaeoclimatol. Palaeoecol., 509 (2018), pp. 47-57, 10.1016/j.palaeo.2017.12.037

A. Licht, M. Van Cappelle, H.A. Abels, J.B. Ladant, J. Trabucho-Alexandre, C. FranceLanord, Y. Donnadieu, J. Vandenberghe, T. Rigaudier, C. Lécuyer, D. Terry Jr., R. A driaens, A. Boura, Z. Guo, Soe Aung Naing, J. Quade, G. Dupont-Nivet, J.J. JaegerAsian monsoons in a late Eocene greenhouse world; Nature, 513 (7519) (2014), pp. 501-506

A. Licht, G. Dupont-

Nivet, A. Pullen, P. Kapp, H.A. Abels, Z. Lai, Z. Guo, J. Abell, D. GieslerResilience of the Asian atmospheric circulation shown by Paleogene dust provenance; Nat. Commun., 7 (2016), Article 12390

K.R. Ludwig, R. MundilExtracting reliable $\mathrm{U}-\mathrm{Pb}$ ages and errors from complex populations of zircons from Phanerozoic tuffs; Goldschmidt Conference Abstracts 2002 (2002); A453

P.L. McFadden, M.W. McElhinnyClassification of the reversal test in palaeomagnetism; Geophys. J. Int., 103 (3) (1990), pp. 725-729, 10.1111/j.1365246X.1990.tb05683.x

P. Molnar, W.R. Boos, D.S. BattistiOrographic controls on climate and paleoclimate of Asia: thermal and mechanical roles for the Tibetan Plateau; Annu. Rev. Earth Planet. Sci., 38 (2010), 10.1146/annurev-earth-040809-152456

C.P. North, S.K. DavidsonUnconfined alluvial flow processes: recognition and interpretation of their deposits, and the significance for palaeogeographic reconstruction; Earth-Sci. Rev., 111 (1) (2012), pp. 199223, 10.1016/j.earscirev.2011.11.008

J.G. Ogg, G. Ogg, F.M. GradsteinA Concise Geologic Time Scale: 2016; Elsevier (2016)

P.E. Potter, J.B. Maynard, P.J. DepetrisMud and Mudstones: Introduction and Overview; Springer Science \& Business Media (2005)

Qinghai Bureau of Geology and Mineral Resources (QBGMR)Geologic Maps of the Duoba, Gaodian, Tianjiazai, and Xining Regions (4 Sheets), with Regional Geologic Report (1:50,000 Scale); (1985); Xining, China, 199 pp

C. Quan, Z. Liu, T. Utescher, J. Jin, J. Shu, Y. Li, Y.S.C. LiuRevisiting the Paleogene climate pattern of East Asia: a synthetic review; Earth-Sci. Rev., 139 (2014), pp. 213230, 10.1016/j.earscirev.2014.09.005

G. Ramstein, F. Fluteau, J. Besse, S. JoussaumeEffect of orogeny, plate motion and landsea distribution on Eurasian climate change over the past 30 million years; Nature, 386 (6627) (1997), pp. 788-795 
G.H. Roe, Q. Ding, D.S. Battisti, P. Molnar, M.K. Clark, C.N. GarzioneA modeling study of the response of Asian summertime climate to the largest geologic forcings of the past 50 Ma; J. Geophys. Res., Atmos., 121 (10) (2016), pp. 54535470, 10.1002/2015JD024370

M.R. RosenThe importance of groundwater in playas: a review of playa classifications and; Paleoclimate and Basin Evolution of Playa Systems, Geological Society of America, Special Papers, vol. 289 (1994), p. 1

J.P. Smoot, T.K. LowensteinDepositional environments of non-marine evaporites; Developments in Sedimentology, vol. 50, Elsevier (1991), pp. 189$347,10.1016 / S 0070-4571(08) 70261-9$

Spicer et al., 2017;

R. Spicer, J. Yang, A. Herman, T. Kodrul, G. Aleksandrova, N. Maslova, T. Spicer, L. Ding, Q. Xu, A. Shukla, G. Srivastava, R. Mehrotra, X.-Y. Liu, J.-H. JinPaleogene monsoons across India and South China: drivers of biotic change; Gondwana Res., 49 (2017), pp. 350-363, 10.1016/j.gr.2017.06.006

J.S. Stacey, J.D. KramerApproximation of terrestrial lead isotope evolution by a two stage model; Earth Planet. Sci. Lett., 26 (1975), pp. 207-221, 10.1016/0012821X(75)90088-6

L.M. Staisch, N.A. Niemi, M.K. Clark, H. ChangEocene to late Oligocene history of crustal shortening within the Hoh Xil Basin and implications for the uplift history of the northern Tibetan Plateau; Tectonics, 35 (4) (2016), pp. 862895, 10.1002/2015TC003972

M.R. Talbot, K. Holm, M.A.J. WilliamsSedimentation in low-gradient desert margin systems: a comparison of the Late Triassic of northwest Somerset (England) and the late Quaternary of east-central Australia; Paleoclimate and Basin Evolution of Playa Systems, Geological Society of America, Special Papers, vol. 289 (1994), pp. 97-117

A. Turtù, V. Lauretano, R. Catanzariti, F.J. Hilgen, S. Galeotti, L. Lanci, M. Moretti, L.J. Lour ensIntegrated stratigraphy of the Smirra Core (Umbria-Marche Basin, Apennines, Italy): a new early Paleogene reference section and implications for the geologic time scale; Palaeogeogr. Palaeoclimatol. Palaeoecol., 487 (2017), pp. 158-174, 10.1016/j.palaeo.2017.08.031

T. Westerhold, U. Röhl, T. Frederichs, C. Agnini, I. Raffi, J.C. Zachos, R.H. WilkensAstrono mical calibration of the Ypresian timescale: implications for seafloor spreading rates and the chaotic behavior of the solar system?; Clim. Past, 13 (9) (2017), p. $1129,10.5194 / \mathrm{cp}-13-1129-2017$

G. Xiao, Z. Guo, G. DupontNivet, H. Lu, N. Wu, J. Ge, Q. Hao, S. Peng, F. Li, H.A. Abels, K. ZhangEvidence for northeastern Tibetan Plateau uplift between 25 and 20 Ma in the sedimentary archive of the Xining Basin, Northwestern China; Earth Planet. Sci. Lett., 317 (2012), pp. 185-195, 10.1016/j.epsl.2011.11.008

Z. Zhang, H. Wang, Z. Guo, D. JiangWhat triggers the transition of palaeoenvironmental patterns in China, the Tibetan Plateau uplift or the Paratethys Sea retreat?; Palaeogeogr. Palaeoclimatol. Palaeoecol., 245 (3-4) (2007), pp. 317331, 10.1016/j.palaeo.2006.08.003

J. Zhang, Y. Wang, B. Zhang, H. ZhaoEvolution of the NE Qinghai-Tibetan Plateau, constrained by the apatite fission track ages of the mountain ranges around the Xining Basin in NW China, J. Asian Earth Sci., 97 (2015), pp. 1023, 10.1016/j.jseaes.2014.10.002 
J. Zhang, Y. Wang, B. Zhang, Y. ZhangTectonics of the Xining Basin in NW China and its implications for the evolution of the NE Qinghai-Tibetan Plateau, Basin

Res., 28 (2) (2016), pp. 159-182, 10.1111/bre.12104 


\section{The following is the Supplementary material related to this article.}

MMC 1. Supplementary material: Analytical procedure for U-Pb geochronology.

Fig. S1. Studied sections showing: a) detailed lithological logs of the studied sections.

b) Virtual Geomagnetic Pole (VGP) latitudes and corresponding polarity zones.

Fig. S2. Total alkali-silica (TAS) diagram (Le Maitre et al., 1989) of the tuff layers (A, B and $\mathrm{C}$ in Fig. 3G) classifying the tuff as trachyte.

Fig. S3. Thermal demagnetization of representative samples shown in vector end point diagrams on the left (numbers indicate temperature steps) and remanent magnetizationon the right. (a) Normal polarity in N3 (Caija, $71.5 \mathrm{~m}$ ). (b) Reversed polarity in R1 (Xiejia, $15.3 \mathrm{~m}$ ). (c) Normal polarity in N5 (Caijia, $188.5 \mathrm{~m}$ ). (d) Normal polarity in N2 (Xiejia, $29.1 \mathrm{~m}$ ). The samples shown in (c) and (d) are from normal polarity zones that were not correlated to the GTS.

Fig. S4. Equal-area stereographic projections in the lower hemisphere of the ChRMs calculated in the different sections. The ChRMs are shown both in situ (IS) and tiltcorrected (TC). Samples removed after $45^{\circ}$ cutoff are indicated in red and samples from normal polarity zones that are not correlated to the GTS are indicated in blue.

Fig. S5. Sediment accumulation rates for the different magnetostratigraphic sections correlated to the GTS16 (Ogg et al., 2016). Rates are shown in cm/kyr.

Table S1. Geochemical analyses of major (\%) and minor (ppm) elements of the three layers within the tuff bed (A, B and C).

Table S2. Operating conditions for the LA-ICP-MS equipment.

Table S3. U-Pb data for the 31 analyzed zircon grains. All errors are listed at $1 \sigma$. Data in bold were used for the tuff age calculation ( $\%$ conc. = Percentage of concordance).

Data 1. U-Pb Pleso standards.

Data 2. Magnetostratigraphy. 


\section{Analytical procedure for U-Pb geochronology}

$4 \quad$ U-Pb geochronology was conducted by in-situ laser ablation inductively coupled plasma mass

9 The ablated material is carried into helium, and then mixed with nitrogen and argon, before

\section{Supplementary material:} spectrometry (LA-ICPMS) at Géosciences Rennes using an ESI NWR193UC excimer laser coupled to a quadripole Agilent 7700x ICP-MS equipped with a dual pumping system to enhance sensitivity (Paquette et al. 2014). The instrumental conditions are reported in Table S2. ( being injected into the plasma source. The alignment of the instrument and mass calibration was performed before the analytical session using the NIST SRM 612 reference glass, by inspecting the ${ }^{238} \mathrm{U}$ signal and by minimizing the $\mathrm{ThO}+/ \mathrm{Th}+$ ratio $(<0.5 \%)$. During the course of an analysis, the signals of ${ }^{204}(\mathrm{~Pb}+\mathrm{Hg}),{ }^{206} \mathrm{~Pb},{ }^{207} \mathrm{~Pb},{ }^{208} \mathrm{~Pb}$ and ${ }^{238} \mathrm{U}$ masses are acquired. The ${ }^{235} \mathrm{U}$ signal is calculated from ${ }^{238} \mathrm{U}$ on the basis of the ratio ${ }^{238} \mathrm{U} /{ }^{235} \mathrm{U}=137.88$.

15

Single analyses consisted of 20 seconds of background integration followed by 60 seconds integration with the laser firing and then a 15 seconds delay to wash out the previous sample. The ESI NWR193UC laser is equipped with a rotational XY shutter, which allows rectangular ablations while ensuring an even "dosage" of the laser energy to the sample during the analyses. Because the zircon grains of the tuff sample are very elongated and narrow, we defined a rectangle of $70 \times 20 \mathrm{~mm}$ that was suitable for most of the grains in this sample. This ablation rectangle, which can rotate freely around its center, was then used for all the standards and the zircon crystals in order to use the same analytical conditions during the analyses. 
The data were corrected for $\mathrm{U}-\mathrm{Pb}$ fractionation and for mass bias by repeated measurements of the Gj1 zircon standard (Jackson et al., 2004). The six Plešovice zircon standard (Sláma et al., 2008) measurements were treated as unknowns and were used to control the reproducibility and accuracy of the corrections. During the course of the analyses, they provided a Concordia age of $337.7 \pm 3.1 \mathrm{Ma}(\mathrm{MSWD}=0.15$, probability=0.999). Data reduction was carried out with the Glitter Software (van Achterbergh et al., 2001). Concordia ages and diagrams were generated using Isoplot/Ex (Ludwig, 2001). All errors given in the data tables are listed at one sigma, but where data are combined for regression analysis, the final results are provided with $95 \%$ confidence limits. Further information on the protocol can be found in Ballouard et al. (2015).

\section{Figure and table captions}

Fig. S1 Studied sections showing: a) detailed lithological logs of the studied sections. b) Virtual Geomagnetic Pole (VGP) latitudes and corresponding polarity zones.

Fig. S2 Total alkali-silica (TAS) diagram (Le Maitre et al., 1989) of the tuff layers (A, B and C in Fig. $3 g$ ) classifying the tuff as trachyte.

Fig. S3 Thermal demagnetization of representative samples shown in vector end point diagrams on the left (numbers indicate temperature steps) and remanent magnetization on the right. (a) Normal polarity in N3 (Caija, 71.5 meter). (b) Reversed polarity in R1 (Xiejia, 15.3 meter). (c) Normal polarity in N5 (Caijia, 188.5 meter). (d) Normal polarity in N2 (Xiejia, 29.1 meter). The samples shown in (c) and (d) are from normal polarity zones that were not correlated to the GTS.

Fig. S4 Equal-area stereographic projections in the lower hemisphere of the ChRMs calculated in the different sections. The ChRMs are shown both in situ (IS) and tilt-corrected (TC). Samples removed after $45^{\circ}$ cutoff are indicated in red and samples from normal polarity zones that are not correlated to the GTS are indicated in blue. 


1

Fig. S5 Sediment accumulation rates for the different magnetostratigraphic sections correlated to the GTS16 (Ogg et al., 2016). Rates are shown in cm/kyr.

Table S1: Geochemical analyses of major (\%) and minor (ppm) elements of the three layers within the tuff bed (A, B and $C)$.

Table S2: Operating conditions for the LA-ICP-MS equipment.

TableS3: U-Pb data for the 31 analyzed zircon grains. All errors are listed at $1 \sigma$. Data in bold were used for the tuff age calculation (\%conc. = Percentage of concordance).

\section{Data1 U-Pb Pleso standards}

Data2 Magnetostratigraphy

\section{Supplementary references:}

Ballouard, C., Boulvais, P., Poujol, M., Gapais, D., Yamato, P., Tartèse, R., and Cuney, M., (2015), Tectonic record, magmatic history and hydrothermal alteration in the Hercynian Guérande leucogranite, Armorican Massif, France: Lithos, v. 220-223, p. 1-22. https://doi.org/10.1016/j.lithos.2015.01.027

Jackson SE, Pearson NJ, Griffin WL, Belousova EA (2004) The application of laser-ablationinductively coupled plasma-mass spectrometry to in situ U-Pb zircon geochronology. Chemical Geology 211:47-69. https://doi.org/10.1016/j.chemgeo.2004.06.017

Le Maitre, R. W., Bateman, P., Dudek, A., Keller, J., Lameyre, J., Le Bas, M., Sabine, P., Schmid, R., Sorensen, H., Streckeisen, A., Woolley, A. R. \& Zanettin, B. (1989). A classification of igneous rocks and glossary of terms: Recommendations of the International Union of Geological Sciences, Subcommission on the Systematics of Igneous Rocks. Blackwell Oxford (193 pp). 
0

Ludwig, K.R. (2001). Isoplot/Ex Version 2.49. A Geochronological Toolkit for Microsoft Excel. Berkeley Geochronology Center, Special, Publication 1app. 1-55.

Ogg, J. G., Ogg, G., \& Gradstein, F. M. (2016). A concise geologic time scale: 2016. Elsevier.

Paquette, J.-L., Piro, J.-L., Devidal, J.-L., Bosse, V., Didier, A., Sanac, S., and Abdelnour, Y. (2014). Sensitivity enhancement in LA-ICP-MS by N2 addition to carrier gas: Application to radiometric dating of U-Th-bearing minerals: Agilent ICP-MS Journal, v. 58, p. 1-5.

Sláma, J., Kosler, D., Condon, D.J., Crowley, J.L., Gerdes, A., Hanchar, J.M., Horstwood,M.S.A., Morris, G.A., Nasdala, L., Norberg, N., Schaltegger, U., Schoene, B., Tubrett, M.N., Whitehouse, M.J. (2008). Plesovice zircon - a new natural reference material for $\mathrm{U}-\mathrm{Pb}$ and $\mathrm{Hf}$ isotopic microanalysis. Chem. Geol. 249, 1-35. https://doi.org/10.1016/j.chemgeo.2007.11.005

Van Achterbergh, E., Ryan, C. G., Jackson, S. E., and Griffin, W. L. (2001). Data reduction software for LA-ICP-MS: appendix, in Sylvester, P. J., ed., Laser Ablation-ICP-Mass Spectrometry in the Earth Sciences: Principles and Applications, Volume 29: Ottawa, Ontario, Canada, Mineralog. Assoc. Canada (MAC), p. 239-243. 


\section{East Xining}

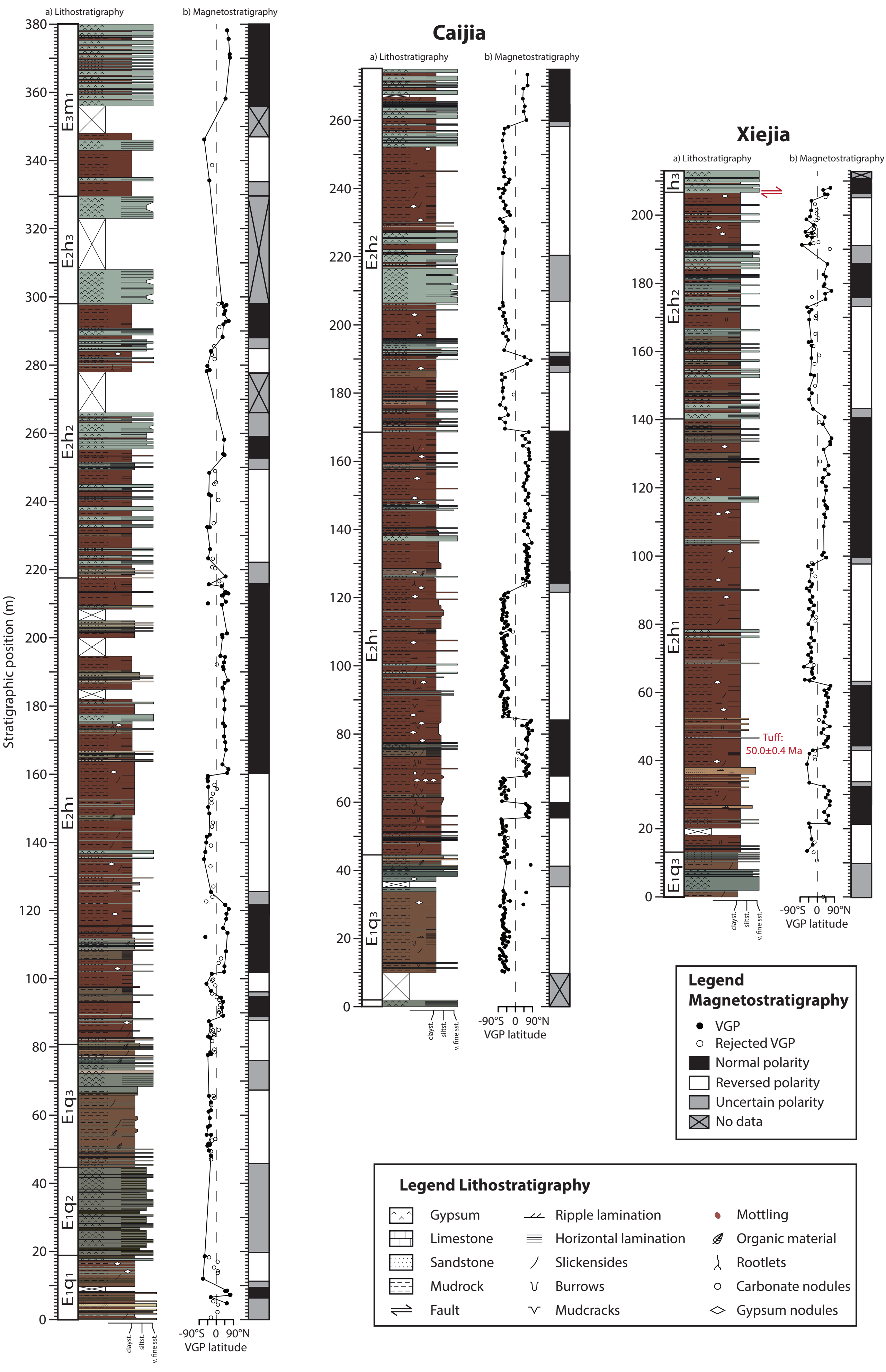




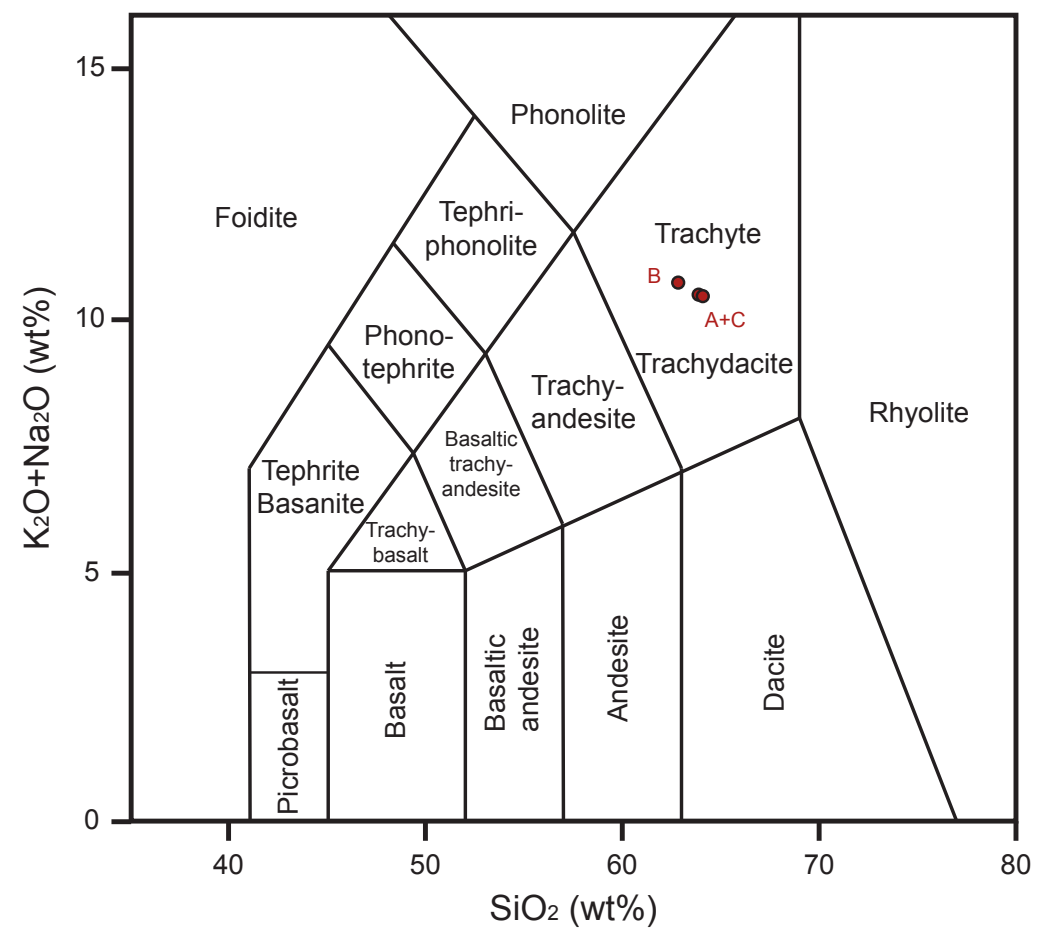


A) Normal polarity (N3)

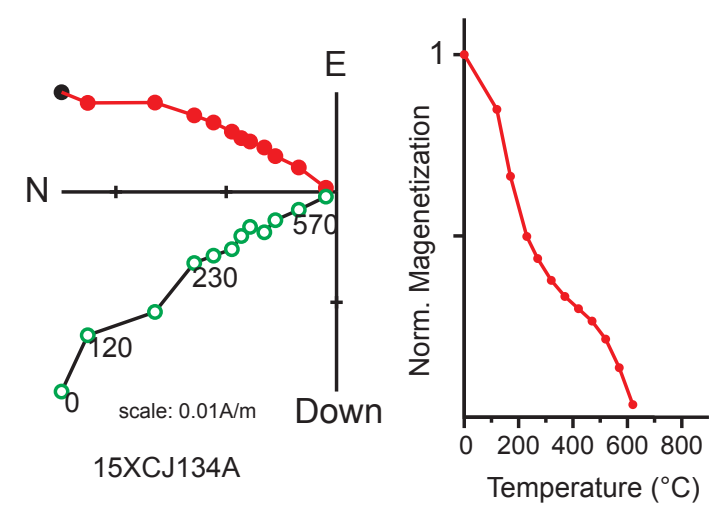

C) Uncorrelated normal polarity zone (N5)

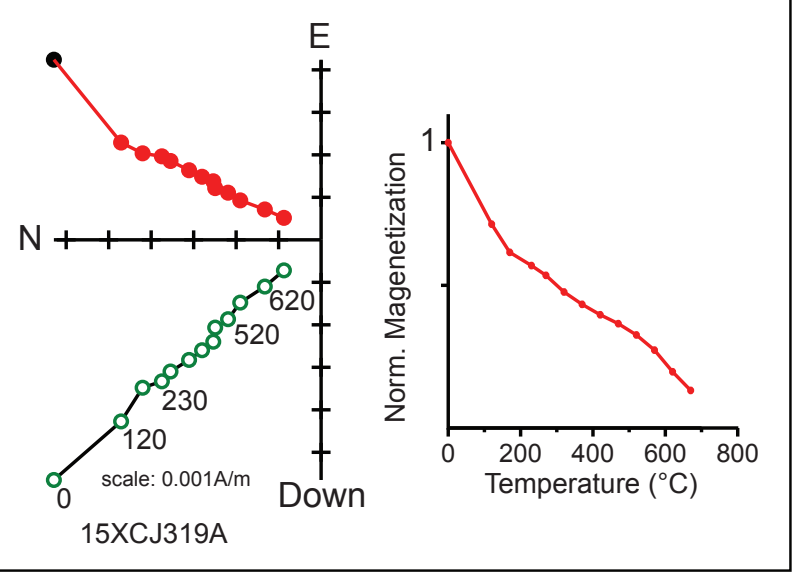

B) Reversed polarity (R1)

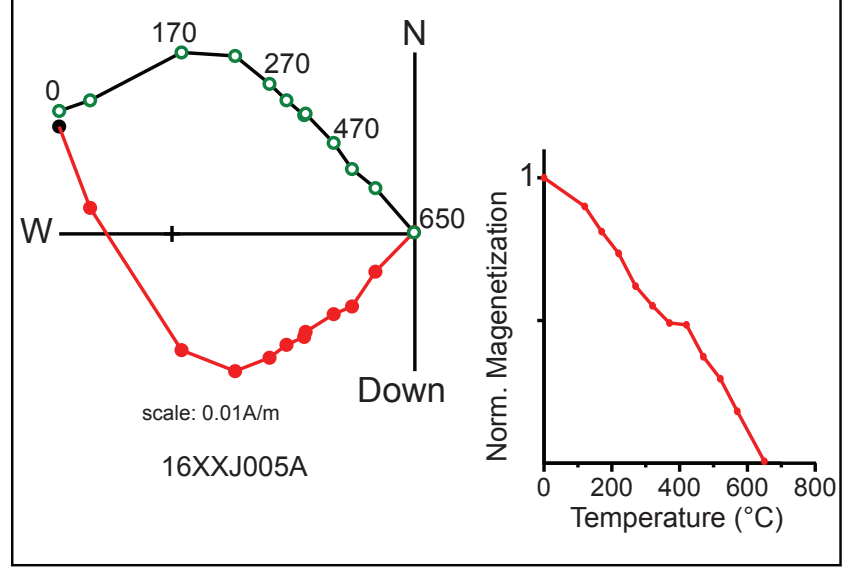

D) Uncorrelated normal polarity zone (N2)

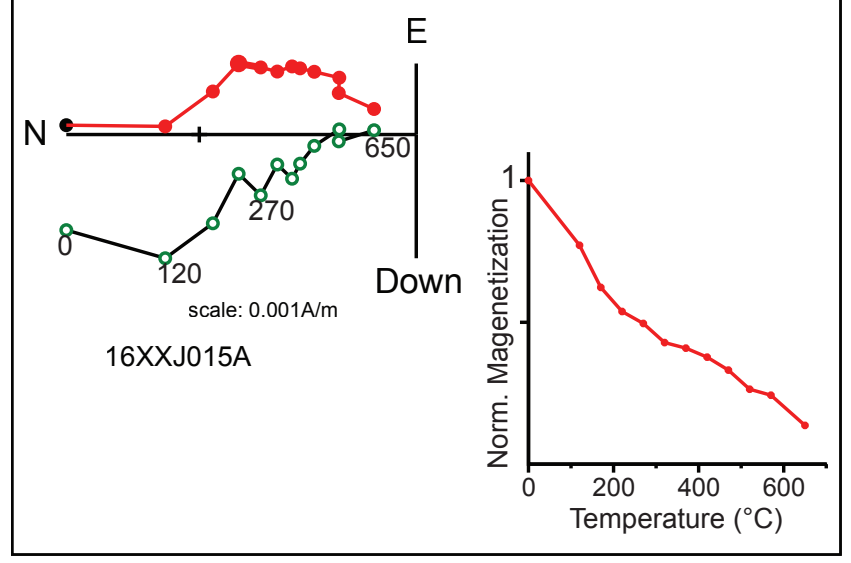




\section{East Xining}

Normal (TC): $\quad \mathrm{D}=3.9^{\circ} ; \mathrm{I}=39.7^{\circ} ; \alpha 95=5.0^{\circ} ; \mathrm{n}=88$ Reversed (TC): $D=208.8^{\circ} ; I=-40.8^{\circ} ; \alpha 95=4.3^{\circ} ; n=127$

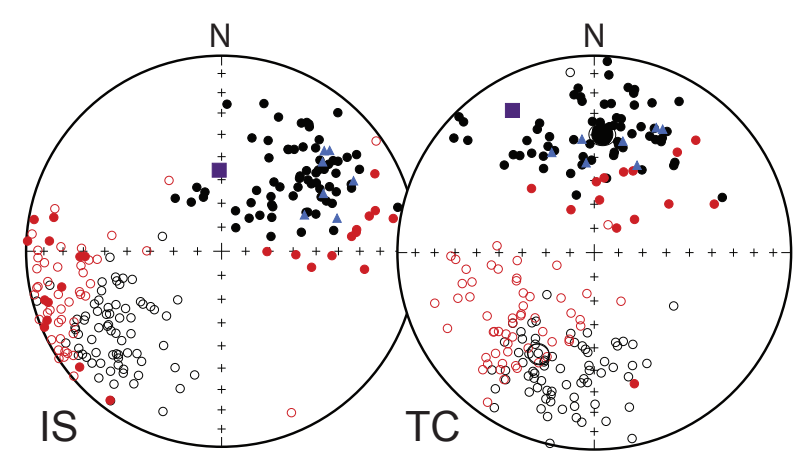

\section{Xiejia}

Normal (TC): $\quad D=16.1^{\circ} ; I=31.2^{\circ} ; \alpha 95=6.0^{\circ} ; n=71$ Reversed (TC): $D=218.3^{\circ} ; I=-37.3^{\circ} ; \alpha 95=5.8^{\circ} ; n=101$

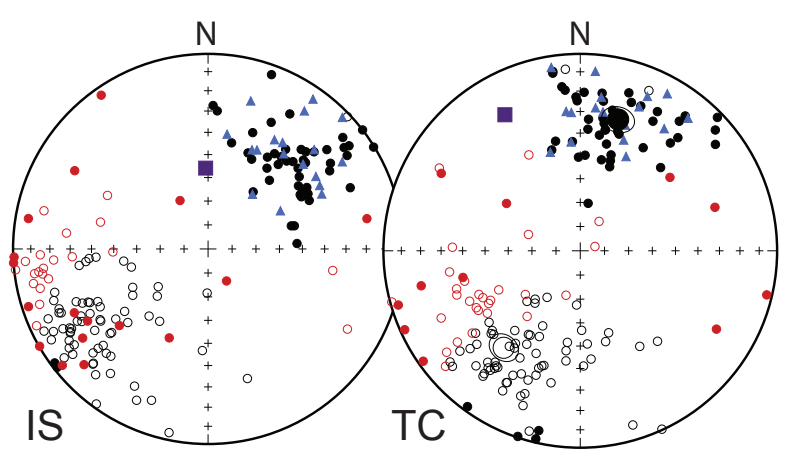

\section{Caijia}

Normal $(T C): \quad D=22.8^{\circ} ; I=36.3^{\circ} ; \alpha 95=4.3^{\circ} ; n=108$ Reversed $(\mathrm{TC})$ : $\mathrm{D}=206.6^{\circ} ; \mathrm{I}=-35.1^{\circ} ; \alpha 95=2.7^{\circ} ; \mathrm{n}=225$

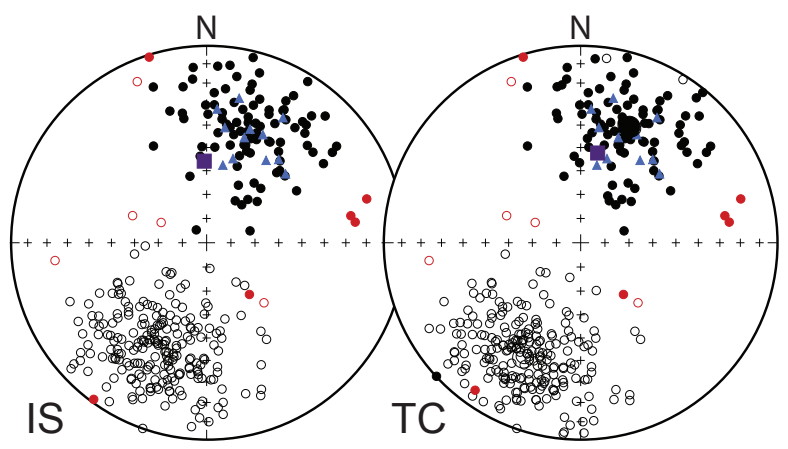

\section{Legend}

- Present day normal

- $\bigcirc$ Directions

- Rejected directions after 45 cutoff

- Directions of uncorrelated normal chrons 


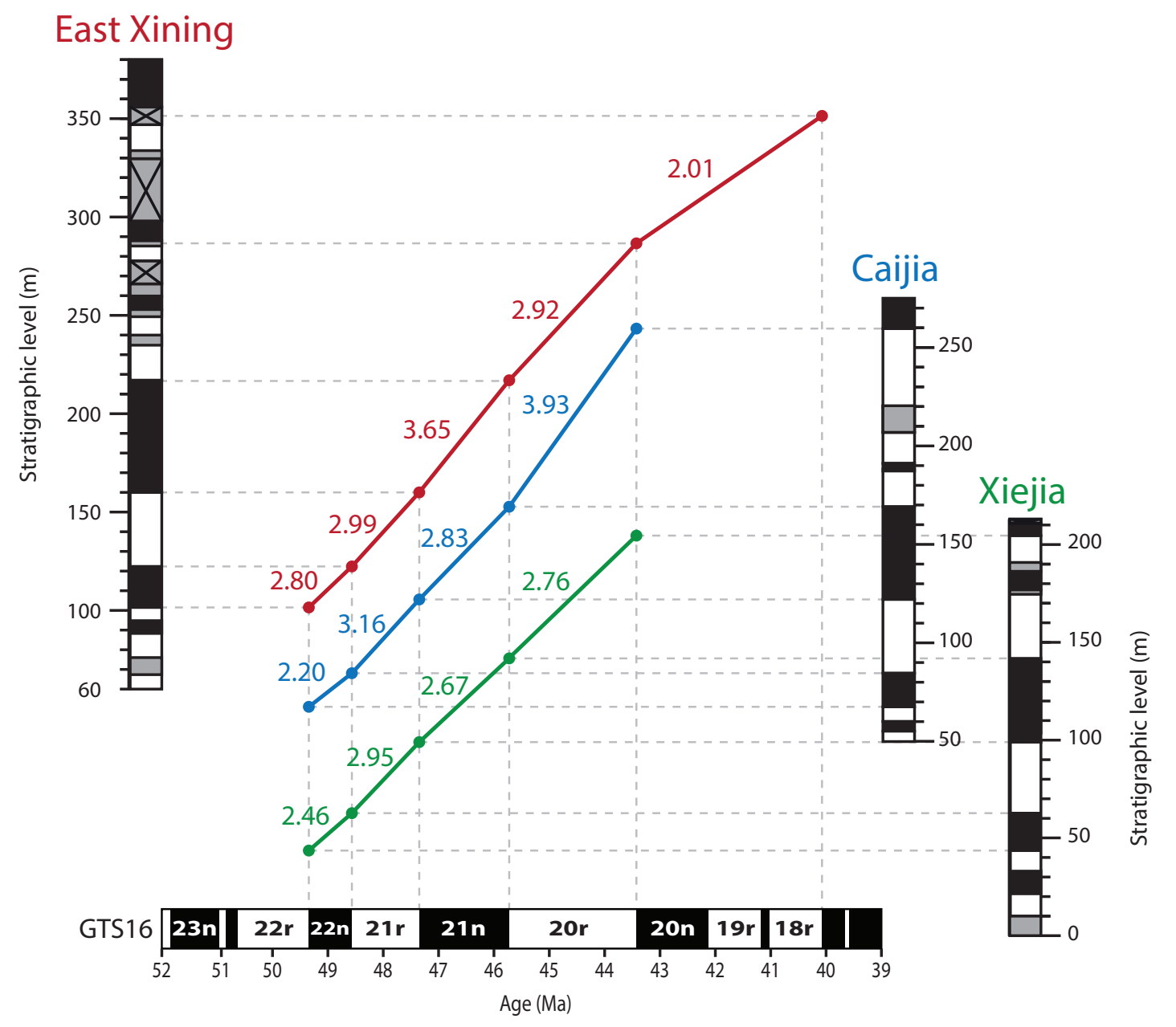




\begin{tabular}{|lcccccccccccc|}
\hline Sample \# & $\begin{array}{c}\mathrm{SiO} 2 \\
(\%)\end{array}$ & $\begin{array}{c}\mathrm{TiO} 2 \\
(\%)\end{array}$ & $\begin{array}{c}\mathrm{Al} 2 \mathrm{O} 3 \\
(\%)\end{array}$ & $\begin{array}{c}\mathrm{Fe} 2 \mathrm{O3} \\
(\%)\end{array}$ & $\begin{array}{c}\mathrm{MnO} \\
(\%)\end{array}$ & $\begin{array}{c}\mathrm{MgO} \\
(\%)\end{array}$ & $\begin{array}{c}\mathrm{CaO} \\
(\%)\end{array}$ & $\begin{array}{c}\mathrm{Na} 2 \mathrm{O} \\
(\%)\end{array}$ & $\begin{array}{c}\mathrm{K} 20 \\
(\%)\end{array}$ & $\begin{array}{c}\mathrm{P} 2 \mathrm{O} 5 \\
(\%)\end{array}$ & $\begin{array}{c}\text { LOI } \\
(\%)\end{array}$ & $\begin{array}{c}\text { Sum } \\
(\%)\end{array}$ \\
\hline XJTUFF C & 58.47 & 0.35 & 18.51 & 1.19 & 0.06 & 0.87 & 2.37 & 8.87 & 0.74 & 0.10 & 8.14 & 99.67 \\
XJTUFF B & 56.88 & 0.33 & 18.37 & 0.90 & 0.09 & 0.76 & 3.37 & 9.10 & 0.62 & 0.09 & 9.28 & 99.79 \\
XJTUFF A & 58.80 & 0.37 & 18.88 & 1.31 & 0.05 & 0.96 & 1.67 & 8.75 & 0.86 & 0.10 & 8.15 & 99.90 \\
\hline Sample \# & $\mathrm{Ba}$ & $\mathrm{Cr}$ & $\mathrm{Ga}$ & $\mathrm{Nb}$ & $\mathrm{Ni}$ & $\mathrm{Rb}$ & $\mathrm{Sr}$ & $\mathrm{V}$ & $\mathrm{Y}$ & $\mathrm{Zn}$ & $\mathrm{Zr}$ & $\begin{array}{c}\text { Sum } \\
(\mathrm{pr}\end{array}$ \\
& $(\mathrm{ppm})$ & $(\mathrm{ppm})$ & $(\mathrm{ppm})$ & $(\mathrm{ppm})$ & $(\mathrm{ppm})$ & $(\mathrm{ppm})$ & $(\mathrm{ppm})$ & $(\mathrm{ppm})$ & $(\mathrm{ppm})$ & $(\mathrm{ppm})$ & $(\mathrm{ppm})$ & $(\mathrm{ppm})$ \\
\hline XJTUFF C & 338 & 35 & 14 & 25 & 19 & 51 & 185 & 102 & 20 & 15 & 106 & 910 \\
XJTUFF B & 325 & 17 & 16 & 26 & 13 & 41 & 277 & 44 & 24 & 24 & 89 & 896 \\
XJTUFF A & 338 & 37 & 15 & 25 & 18 & 49 & 206 & 64 & 21 & 30 & 100 & 903 \\
\hline
\end{tabular}




\begin{tabular}{|l|l|}
\hline $\begin{array}{l}\text { Laboratory \& Sample } \\
\text { Preparation }\end{array}$ & \\
\hline Laboratory name & Géosciences Rennes, UMR CNRS 6118, Rennes, France \\
\hline Sample type/mineral & Detrital and magmatic zircon grains \\
\hline Sample preparation & $\begin{array}{l}\text { Conventional mineral separation, 1 inch resin mount, 1mm polish to } \\
\text { finish }\end{array}$ \\
\hline Imaging & $\begin{array}{l}\text { CL: RELION CL instrument, Olympus Microscope BX51WI, Leica } \\
\text { Color Camera DFC 420C }\end{array}$ \\
\hline Laser ablation system & \\
\hline Make, Model \& type & ESI NWR193UC, Excimer \\
\hline Ablation cell & ESI NWR TwoVol2 \\
\hline Laser wavelength & $193 \mathrm{~nm}$ \\
\hline Pulse width & $<5 \mathrm{~ns}$ \\
\hline Fluence & $8.0 \mathrm{~J} / \mathrm{cm}{ }^{2}$ \\
\hline Spepetition rate & $3 \mathrm{~Hz}$ \\
\hline
\end{tabular}




\begin{tabular}{|c|c|}
\hline Carrier gas & $\begin{array}{l}100 \% \mathrm{He}, \text { Ar make-up gas and N2 }(3 \mathrm{ml} / \mathrm{mn}) \text { combined using in- } \\
\text { house smoothing device }\end{array}$ \\
\hline Background collection & 20 seconds \\
\hline Ablation duration & 60 seconds \\
\hline Wash-out delay & 15 seconds \\
\hline $\begin{array}{l}\text { Cell carrier gas flow } \\
(\mathrm{He})\end{array}$ & $0.72 \mathrm{l} / \mathrm{min}$ \\
\hline ICP-MS Instrument & \\
\hline Make, Model \& type & Agilent 7700x, Q-ICP-MS \\
\hline Sample introduction & Via conventional tubing \\
\hline RF power & $1350 W$ \\
\hline Sampler, skimmer cones & $\mathrm{Ni}$ \\
\hline Extraction lenses & X type \\
\hline Make-up gas flow (Ar) & $0.81 \mathrm{l} / \mathrm{min}$ \\
\hline Detection system & Single collector secondary electron multiplier \\
\hline Data acquisition protocol & Time-resolved analysis \\
\hline Scanning mode & Peak hopping, one point per peak \\
\hline
\end{tabular}




\begin{tabular}{|c|c|}
\hline Detector mode & $\begin{array}{l}\text { Pulse counting, dead time correction applied, and analog mode when signal } \\
\text { intensity }>\sim 10^{\circ} \mathrm{cps}\end{array}$ \\
\hline Masses measured & ${ }^{204}(\mathrm{Hg}+\mathrm{Pb}),{ }^{206} \mathrm{~Pb},{ }^{207} \mathrm{~Pb},{ }^{208} \mathrm{~Pb},{ }^{232} \mathrm{Th},{ }^{238} \mathrm{U}$ \\
\hline $\begin{array}{l}\text { Integration time per } \\
\text { peak }\end{array}$ & $10-30 \mathrm{~ms}$ \\
\hline Sensitivity / Efficiency & $24000 \mathrm{cps} / \mathrm{ppm} \mathrm{Pb}(50 \mu \mathrm{m}, 10 \mathrm{~Hz})$ \\
\hline Data Processing & \\
\hline Gas blank & 20 seconds on-peak \\
\hline Calibration strategy & $\begin{array}{l}\text { GJ1 zircon standard used as primary reference material, Plešovice } \\
\text { used as secondary reference material (quality control) }\end{array}$ \\
\hline Reference Material info & $\begin{array}{l}\text { GJ1 (Jackson et al., 2004) } \\
\text { Plešovice (Slama et al., 2008) }\end{array}$ \\
\hline $\begin{array}{l}\text { Data processing } \\
\text { package used }\end{array}$ & GLITTER $®$ (van Achterbergh et al., 2001) \\
\hline $\begin{array}{l}\text { Quality control / } \\
\text { Validation }\end{array}$ & $\begin{array}{l}\text { Plešovice: } \text { concordia age }=337.7 \pm 3.1 \mathrm{Ma}(\mathrm{N}=6 \text {; } \mathrm{MSWD}=0.15 \text {; } \\
\text { probability }=0.999)\end{array}$ \\
\hline
\end{tabular}


Isotopic ratios

\begin{tabular}{|c|c|c|c|}
\hline Grain number & $\mathrm{Pb}(p p m)$ & $U(p p m)$ & Th (ppm) \\
\hline Zr1 & 95 & 1559 & 343 \\
\hline Zr3 & 97 & 163 & 145 \\
\hline Zr5 & 9 & 986 & 823 \\
\hline Zr7 & 128 & 1093 & 283 \\
\hline Zr9 & 32 & 219 & 120 \\
\hline Zr10 & 3 & 346 & 195 \\
\hline Zr11 & 4 & 503 & 387 \\
\hline Zr13 & 7 & 744 & 687 \\
\hline Zr14 & 7 & 832 & 802 \\
\hline Zr16 & 9 & 999 & 797 \\
\hline Zr17 & 4 & 433 & 310 \\
\hline Zr18 & 4 & 492 & 278 \\
\hline Zr20 & 5 & 550 & 457 \\
\hline Zr21 & 11 & 228 & 108 \\
\hline Zr22 & 9 & 146 & 148 \\
\hline Zr27 & 6 & 632 & 471 \\
\hline zr28 & 4 & 465 & 197 \\
\hline Zr29 & 7 & 818 & 646 \\
\hline Zr31 & 6 & 607 & 527 \\
\hline Zr34 & 5 & 525 & 365 \\
\hline Zr36 & 5 & 502 & 373 \\
\hline Zr38 & 9 & 904 & 850 \\
\hline Zr39 & 6 & 706 & 544 \\
\hline Zr40 & 11 & 98 & 88 \\
\hline Zr41 & 4 & 371 & 438 \\
\hline Zr42 & 50 & 326 & 91 \\
\hline Zr43 & 9 & 895 & 787 \\
\hline Zr44 & 18 & 435 & 226 \\
\hline Zr45 & 11 & 161 & 122 \\
\hline Zr47 & 21 & 348 & 152 \\
\hline Zr48 & 43 & 342 & 114 \\
\hline
\end{tabular}

Apparent Ages

\begin{tabular}{|c|c|c|c|c|c|c|c|c|c|}
\hline & $238 \mathrm{U} / 206 \mathrm{~Pb}$ & Error (\%) & $207 \mathrm{~Pb} / 206 \mathrm{~Pb}$ & & $206 \mathrm{~Pb} / 238 \mathrm{U}$ & Abs.Err & $207 \mathrm{~Pb} / 235 \mathrm{U}$ & Abs.Err & \% Conc. \\
\hline 0.2 & 17.33 & 1.16 & 0.1053 & 1.02 & 362 & & 618 & 5 & 59 \\
\hline 0.9 & 2.111 & 1.17 & 0.1753 & 1.01 & 2500 & 24 & 2560 & 11 & 98 \\
\hline 0.8 & 128.4 & 1.16 & 0.0486 & 1.28 & 50.0 & 0.6 & 51.6 & 0.7 & 97 \\
\hline 0.3 & 9.04 & 1.17 & 0.1057 & 1.01 & 676 & & 975 & 7 & 69 \\
\hline 0.5 & 7.363 & 1.17 & 0.0670 & 1.03 & 821 & & 825 & 7 & 99 \\
\hline 0.6 & 127.6 & 1.15 & 0.0506 & 1.62 & 50.3 & 0.6 & 54 & 0.9 & 93 \\
\hline 0.8 & 127.2 & 1.15 & 0.0496 & 1.53 & 50.5 & 0.6 & 53.1 & 0.84 & 95 \\
\hline 0.9 & 129.5 & 1.17 & 0.0489 & 1.60 & 49.6 & 0.6 & 51.5 & 0.84 & 96 \\
\hline 1.0 & 131.8 & 1.19 & 0.0512 & 1.23 & 48.7 & 0.6 & 53 & 0.7 & 92 \\
\hline 0.8 & 128.0 & 1.15 & 0.0482 & 1.39 & 50.1 & 0.6 & 51.3 & 0.75 & 98 \\
\hline 0.7 & 127.9 & 1.15 & 0.0476 & 1.57 & 50.2 & 0.6 & 50.9 & 0.83 & 99 \\
\hline 0.6 & 125.8 & 1.26 & 0.0501 & 1.46 & 51.1 & 0.6 & 54.4 & 0.83 & 94 \\
\hline 0.8 & 128.4 & 1.16 & 0.0501 & 1.34 & 50.0 & 0.6 & 53.2 & 0.76 & 94 \\
\hline 0.5 & 21.03 & 1.18 & 0.0633 & 1.12 & 300 & & 352 & 4 & 85 \\
\hline 1.0 & 20.46 & 1.19 & 0.0595 & 1.18 & 308 & & 342 & 4 & 90 \\
\hline 0.7 & 128.9 & 1.16 & 0.0540 & 1.32 & 49.8 & 0.6 & 57 & 0.79 & 87 \\
\hline 0.4 & 125.0 & 1.25 & 0.0502 & 2.95 & 51.4 & 0.7 & 54.7 & 1.57 & 94 \\
\hline 0.8 & 129.4 & 1.16 & 0.0524 & 1.35 & 49.6 & 0.6 & 55.2 & 0.78 & 90 \\
\hline 0.9 & 123.9 & 1.24 & 0.0491 & 1.53 & 51.8 & 0.6 & 54.1 & 0.84 & 96 \\
\hline 0.7 & 129.4 & 1.16 & 0.0502 & 1.75 & 49.6 & 0.6 & 52.9 & 0.94 & 94 \\
\hline 0.7 & 129.2 & 1.16 & 0.0535 & 1.53 & 49.7 & 0.6 & 56.4 & 0.89 & 88 \\
\hline 0.9 & 124.8 & 1.12 & 0.0474 & 1.24 & 51.5 & 0.6 & 51.8 & 0.69 & 99 \\
\hline 0.8 & 130.9 & 1.18 & 0.0487 & 1.58 & 49.1 & 0.6 & 50.8 & 0.83 & 97 \\
\hline 0.9 & 10.35 & 1.16 & 0.0608 & 1.10 & 595 & & 602 & 6 & 99 \\
\hline 1.2 & 126.4 & 1.14 & 0.0512 & 1.76 & 50.8 & 0.6 & 55.2 & 0.97 & 92 \\
\hline 0.3 & 6.576 & 1.16 & 0.0696 & 1.05 & 913 & 10 & 914 & 7 & 100 \\
\hline 0.9 & 126.4 & 1.14 & 0.0621 & 1.22 & 50.8 & 0.6 & 66.5 & 0.86 & 76 \\
\hline 0.5 & 26.69 & 1.15 & 0.0653 & 1.07 & 237 & & 295 & 3 & 80 \\
\hline 0.8 & 17.30 & 1.16 & 0.0593 & 1.11 & 362 & & 393 & 4 & 92 \\
\hline 0.4 & 17.11 & 1.16 & 0.0614 & 1.11 & 366 & & 408 & 4 & 90 \\
\hline 0.3 & 7.988 & 1.16 & 0.0654 & 1.05 & 760 & & 767 & 6 & 99 \\
\hline
\end{tabular}




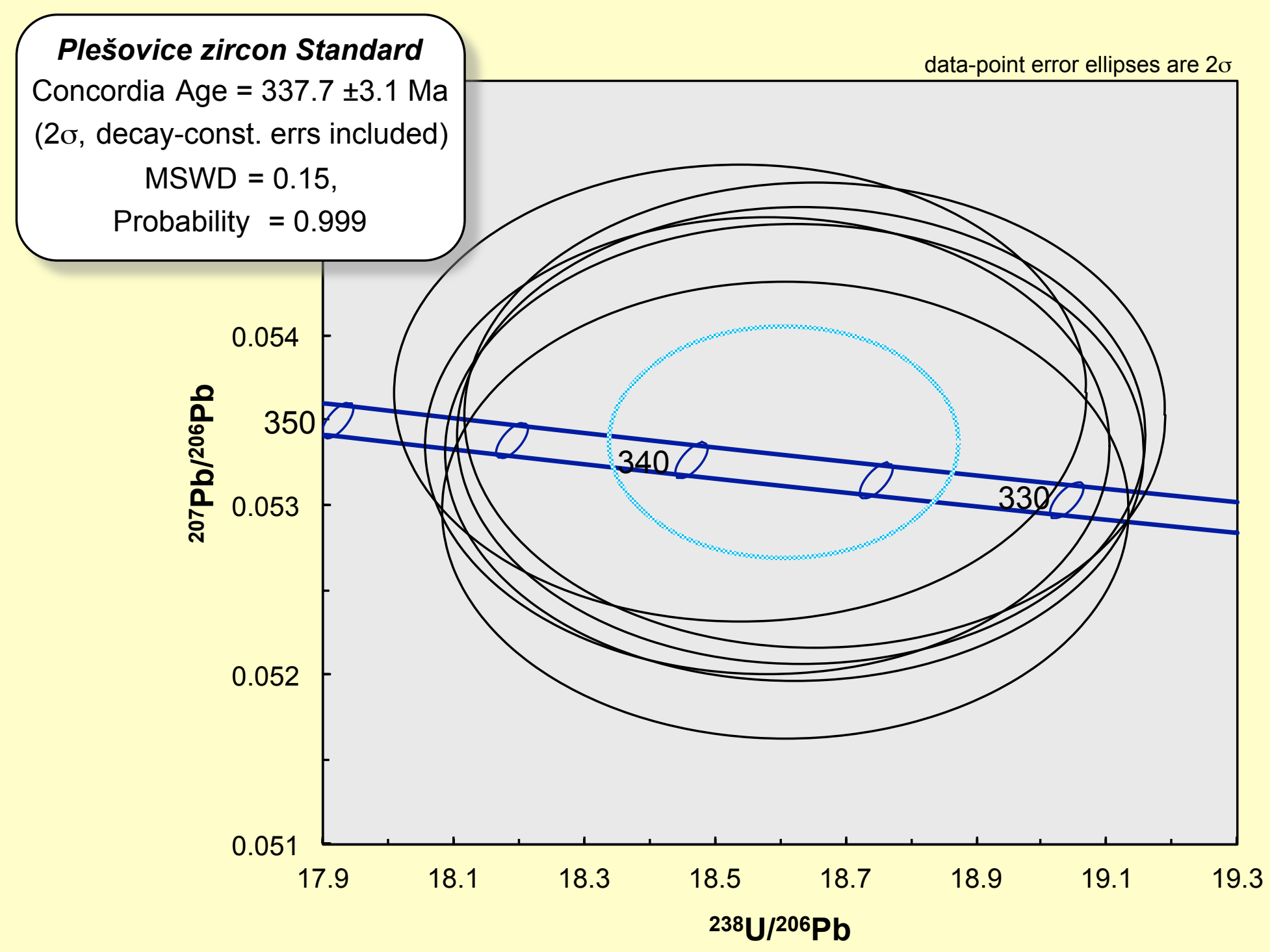


East Xining $(m) \quad$ Cajiia $(m) \quad$ Xiejia $(m)$

Base C22n

Top C22n

101.7

$67.35 \quad 43.5$

Base C21n

$84.5 \quad 62.65$

op C21n

159.85

$123 \quad 98.5$

Base C20n

141.9

352

$259 \quad 205.05$ 


\begin{tabular}{|c|c|c|c|c|c|c|c|c|c|c|}
\hline Sample & Strat. Pos. ( fo & of & lination & hation & MAD & Min Temp i & emp & latitud & Longitı & e from the mean \\
\hline EX008 & 4.80 & 4 & 42.2 & 53.4 & 9.4 & 300 & 450 & 55.7 & 183.5 & 20.2 \\
\hline EX10 & 6.60 & 4 & 239.9 & -16.4 & 5 & 300 & 450 & -29 & 23.7 & 136.7 \\
\hline EX011 & 7.20 & 4 & -21.2 & 61.3 & 4.5 & 300 & 450 & 72.7 & 38.1 & 31.3 \\
\hline EX11 & 7.20 & 4 & -15.7 & 64.3 & 3.1 & 300 & 450 & 74.9 & 55.7 & 30.5 \\
\hline EX13 & $8.5 \circ$ & 4 & 42.3 & 29.3 & 5.2 & 300 & 450 & 47.2 & 209.7 & 22.6 \\
\hline EX013 & $8.5 \circ$ & 4 & 33.1 & 37.8 & 5.4 & 300 & 450 & 57.4 & 210.9 & 11.7 \\
\hline EX14 & 120 & 3 & 192.3 & -35.5 & 2.1 & 300 & 400 & -69.9 & 66.1 & 172.7 \\
\hline EX20 & $18.6 \circ$ & 4 & 211.6 & -42.8 & 7.2 & 300 & 450 & -60.6 & 26.3 & 170.1 \\
\hline EX39 & 48.10 & 4 & 254.7 & -46.6 & 4.9 & 300 & 450 & -27.8 & 356.4 & 139.9 \\
\hline EX044 & 49.6 o & 4 & 236.8 & -37.7 & 1.4 & 300 & 390 & -38.7 & 13 & 150.4 \\
\hline EX46 & 510 & 4 & 218.9 & -21 & 0.7 & 300 & 450 & -46.5 & 38.1 & 153.5 \\
\hline EX47 & 51.2 o & 4 & 229.2 & -13.5 & 8.9 & 300 & 450 & -36.3 & 33.1 & 141.7 \\
\hline EX48 & 51.4 o & 4 & 233.5 & -12.5 & 2.6 & 300 & 450 & -32.7 & 30.2 & 138.2 \\
\hline EX49 & 51.6 o & 4 & 238.1 & -49.6 & 1.2 & 300 & 450 & -41.9 & 1.5 & 151.2 \\
\hline EX053 & 54.2 o & 4 & 254.2 & -43.6 & 6.4 & 300 & 450 & -27 & 359 & 139.5 \\
\hline EX53 & 54.2 o & 4 & 219.6 & -32.6 & 4.7 & 300 & 450 & -50.4 & 29.5 & 161.2 \\
\hline EX55 & 56.5 o & 4 & 219 & -13.6 & 3.2 & 300 & 450 & -43.7 & 42.1 & 147.3 \\
\hline EX057 & 56.9 o & 4 & 241.3 & -33.3 & 4.6 & 300 & 450 & -33.5 & 13.3 & 145.4 \\
\hline EX59 & 59.1 o & 4 & 243.2 & -39.3 & 1.3 & 300 & 450 & -34.1 & 8.1 & 146.2 \\
\hline EX062 & 610 & 4 & 232.2 & -32.1 & 2.2 & 300 & 450 & -40.4 & 20.1 & 151.7 \\
\hline EX63 & $61.4 \circ$ & 4 & 241.8 & -16.3 & 4.9 & 300 & 450 & -27.5 & 22.5 & 135.4 \\
\hline EX068 & 63.7 o & 4 & 248.3 & -32.9 & 5.7 & 300 & 450 & -27.8 & 9.5 & 140 \\
\hline EX72 & $65.6 \circ$ & 4 & 234.3 & -31 & 2.7 & 300 & 450 & -38.3 & 19.4 & 149.6 \\
\hline EX92 & 77.6 o & 4 & 224.9 & -26.2 & 2.8 & 300 & 450 & -44 & 29.6 & 153.7 \\
\hline EX93 & 77.9 o & 4 & 244.8 & -19.4 & 2.6 & 300 & 450 & -26.1 & 19 & 135.2 \\
\hline EX94 & 78.4 o & 4 & 235.8 & -12.7 & 3.7 & 300 & 450 & -31 & 28.4 & 136.9 \\
\hline EX99 & 82.70 & 4 & 234 & -10.4 & 4 & 300 & 450 & -31.6 & 30.7 & 136.3 \\
\hline EX100 & 830 & 4 & 222.8 & -17.5 & 2.9 & 300 & 450 & -42.4 & 36.4 & 148.6 \\
\hline EX107 & 86.40 & 4 & 252 & -44.4 & 3.4 & 300 & 450 & -29 & 359.5 & 141.2 \\
\hline EX108 & 87.5 o & 4 & 239.2 & -42.3 & 2.5 & 300 & 450 & -38.4 & 7.9 & 149.9 \\
\hline EX109 & 89.1 o & 4 & 60.4 & 39.9 & 2.9 & 300 & 450 & 36.6 & 189.1 & 31.6 \\
\hline EX113 & 91.5 o & 4 & 61.9 & 24.5 & 2.5 & 300 & 450 & 30.1 & 198.2 & 39.5 \\
\hline EX115 & $93.2 \circ$ & 4 & 66.3 & 51.8 & 3.8 & 300 & 450 & 36.3 & 175.5 & 34 \\
\hline EX118 & 94.4 o & 4 & 74 & 38.5 & 5.8 & 300 & 450 & 25.2 & 182.8 & 42 \\
\hline EX121 & 96.4 o & 4 & 242.5 & -16.6 & 5 & 300 & 450 & -27.1 & 21.9 & 135.1 \\
\hline EX123 & $98.5 \circ$ & 4 & 213.8 & -24.6 & 2.3 & 300 & 450 & -51.5 & 41.1 & 159.2 \\
\hline EX127 & 101.4 o & 4 & 255.6 & -37 & 1.8 & 300 & 450 & -23.4 & 2.9 & 136.3 \\
\hline EX128 & 102 o & 4 & 54.2 & 40 & 3.2 & 300 & 450 & 41.6 & 192.7 & 27 \\
\hline EX130 & 103.6 o & 4 & 50 & 35.6 & 1.5 & 300 & 450 & 43.4 & 199.1 & 25.2 \\
\hline EX137 & 108 o & 4 & 38 & 32.8 & 13.1 & 300 & 450 & 51.7 & 210.7 & 17.6 \\
\hline EX138 & 112.20 & 4 & 222.1 & -62.6 & 5.2 & 300 & 450 & -57.4 & 345.4 & 154.2 \\
\hline EX139 & 113.4 o & 4 & 23 & 26.4 & 2.2 & 300 & 450 & 59.4 & 233.6 & 15.1 \\
\hline EX141 & 114.8 o & 4 & 59.1 & 35.9 & 2.5 & 300 & 450 & 36.2 & 192.9 & 31.9 \\
\hline EX145 & $117.5 \circ$ & 4 & 31.9 & 23.8 & 5.8 & 300 & 450 & 52.6 & 223.8 & 20.5 \\
\hline EX147 & 119 o & 4 & 31.1 & 78.6 & 3 & 300 & 450 & 54 & 121 & 38 \\
\hline EX149 & 120.4 o & 4 & 29.9 & 60.6 & 5.8 & 300 & 450 & 66.4 & 170.5 & 20.8 \\
\hline EX150 & $121.6 \circ$ & 4 & 56 & 64.7 & 5.4 & 300 & 450 & 47.8 & 160 & 31.9 \\
\hline EX155 & 125.4 o & 4 & 244.5 & -23.9 & 1.8 & 300 & 450 & -27.8 & 16.9 & 138.2 \\
\hline EX169 & 135 o & 4 & 201.8 & -36.1 & 0.7 & 300 & 450 & -64.7 & 47 & 174.4 \\
\hline EX172 & 137.1 o & 4 & 220.4 & -54.2 & 1.6 & 300 & 450 & -57.3 & 2.9 & 160.3 \\
\hline EX175 & 139.9 o & 4 & 216 & -31 & 2.1 & 300 & 450 & -52.5 & 34.2 & 162.7 \\
\hline EX177 & 141.6 o & 4 & 213.5 & -19.8 & 3.5 & 300 & 450 & -49.9 & 44.4 & 155.3 \\
\hline EX178 & 142.20 & 4 & 235.8 & -20.8 & 6 & 300 & 450 & -33.7 & 24.4 & 142.6 \\
\hline EX185 & 148.4 o & 4 & 237 & -31.6 & 2.1 & 300 & 450 & -36.4 & 17.2 & 147.8 \\
\hline EX187 & 150.3 o & 4 & 233.7 & -42 & 1.3 & 300 & 450 & -42.7 & 11.2 & 153.8 \\
\hline EX196 & 156.2 o & 4 & 226.4 & -24.2 & 1 & 300 & 450 & -42.1 & 29.5 & 151.3 \\
\hline EX199 & 157.9 o & 4 & 224 & -25 & 6.9 & 300 & 450 & -44.3 & 31.1 & 153.4 \\
\hline EX201 & 158.6 o & 4 & 227.7 & -37.4 & 6.3 & 300 & 450 & -45.9 & 19.1 & 157.2 \\
\hline EX203 & 159.3 o & 4 & 225.7 & -25.8 & 6.4 & 300 & 450 & -43.2 & 29.1 & 152.8 \\
\hline EX205 & 159.4 o & 4 & 222.3 & -22.5 & 3.1 & 300 & 450 & -44.6 & 34.1 & 152.8 \\
\hline EX207 & $160.3 \circ$ & 4 & -41.2 & 60.5 & 8.6 & 300 & 450 & 57.9 & 33.6 & 40.7 \\
\hline EX209 & 161.4 o & 4 & -31.7 & 65.9 & 6.7 & 300 & 450 & 64.1 & 48.6 & 37.2 \\
\hline EX211 & $162.8 \circ$ & 4 & 62.6 & 34.3 & 2.1 & 300 & 450 & 32.8 & & 35.2 \\
\hline EX215 & 167.1 o & 4 & 35.2 & 23.2 & 2.9 & 300 & 450 & 50 & 220.5 & 22.7 \\
\hline EX219 & 169.3 o & 4 & 46.5 & 39.9 & 2.5 & 300 & 450 & 47.7 & 197.8 & 21.2 \\
\hline EX223 & 171 o & 4 & 51.4 & 33.3 & 3 & 300 & 450 & 41.5 & 199.8 & 27.1 \\
\hline EX227 & 174 o & 4 & 50.5 & 42.2 & 2.2 & 300 & 450 & 45.4 & 193 & 23.8 \\
\hline EX229 & 174.8 o & 4 & 65.6 & 50 & 1 & 300 & 450 & 36.2 & 177.6 & 33.6 \\
\hline EX231 & 179 o & 4 & 53.1 & 42.1 & 2.3 & 300 & 450 & 43.2 & 191.5 & 25.7 \\
\hline EX235 & 181.6 o & 4 & 50.3 & 37.3 & 4.4 & 300 & 450 & 43.8 & 197.4 & 24.8 \\
\hline EX237 & $185 \circ$ & 4 & 55.7 & 29.9 & 3.2 & 300 & 450 & 36.9 & 199.2 & 32 \\
\hline EX238 & $185.3 \circ$ & 4 & 54.4 & 16.2 & 1.9 & 300 & 450 & 33.3 & 207.7 & 39.6 \\
\hline EX239 & 186.7 o & 4 & 47.2 & 32 & 0.6 & 300 & 450 & 44.3 & 203.7 & 24.6 \\
\hline EX241 & 187.4 o & 4 & 16 & 22.5 & 1 & 300 & 450 & 61.2 & 247.7 & 18.6 \\
\hline EX243 & 190.7 o & 4 & 57.6 & 40.2 & 2.2 & 300 & 450 & 38.9 & 190.6 & 29.4 \\
\hline EX245 & 191.4 o & 4 & 53.2 & 20.9 & 2.2 & 300 & 450 & 35.7 & 206.2 & 35.6 \\
\hline EX248 & 192.7 o & 4 & 40 & 8.3 & 1.3 & 300 & 450 & 41 & 223.6 & 37.9 \\
\hline EX249 & 194.3 o & 4 & 41.2 & 25.2 & 1.8 & 300 & 450 & 46.4 & 213.4 & 24.6 \\
\hline EX250 & 194.6 o & 4 & 79.5 & 41.3 & 1.7 & 300 & 450 & 22 & 178 & 44.9 \\
\hline
\end{tabular}




\begin{tabular}{|c|c|c|c|c|c|c|c|c|c|c|}
\hline EX251 & 200.1 o & 4 & 68.5 & 47 & 2.2 & 300 & 450 & 32.8 & 179 & 35.8 \\
\hline EX252 & 200.80 & 4 & 66.6 & 38.3 & 1.5 & 300 & 450 & 31 & 186.9 & 36.7 \\
\hline EX253 & 201.20 & 4 & 39.8 & 72.1 & 6.9 & 300 & 450 & 56.6 & 141 & 32.8 \\
\hline EX254 & 209.60 & 4 & 76.6 & 55.5 & 2.2 & 300 & 450 & 30.1 & 167.2 & 39.9 \\
\hline EX255 & 2100 & 4 & 228.2 & -32 & 2.9 & 300 & 450 & -43.5 & 23 & 154.6 \\
\hline EX256 & $210.5 \circ$ & 4 & 33.5 & 22.1 & 1.1 & 300 & 450 & 50.8 & 223 & 22.7 \\
\hline EX257 & $212.3 \circ$ & 4 & 59.3 & 19.1 & 2.3 & 300 & 450 & 30.4 & 202.8 & 41 \\
\hline EX258 & 212.50 & 4 & 52.3 & 25.7 & 1.1 & 300 & 450 & 38.1 & 204.1 & 31.8 \\
\hline EX259 & $212.9 \circ$ & 4 & 31.3 & 66.3 & 1.6 & 300 & 450 & 64.2 & 153.9 & 26.3 \\
\hline EX260 & 213.10 & 4 & 42.1 & 59.1 & 4.2 & 300 & 450 & 57.1 & 173 & 23.4 \\
\hline EX261 & 213.40 & 4 & 52.3 & 51.8 & 2.5 & 300 & 450 & 47.3 & 181.5 & 25.4 \\
\hline EX262 & 2150 & 4 & 64.1 & 27 & 1.4 & 300 & 450 & 29.2 & 195.5 & 39.8 \\
\hline EX263 & $215.6 \circ$ & 4 & 224.1 & -10.7 & 2.9 & 300 & 450 & -39 & 38.7 & 142.2 \\
\hline EX266 & 217.9 o & 4 & 46.2 & 43.7 & 6.1 & 300 & 450 & 49.4 & 194.2 & 20.5 \\
\hline EX271 & 223.20 & 4 & 216.6 & -5.3 & 3.1 & 300 & 450 & -42.2 & 48.4 & 140.8 \\
\hline EX272 & $225.9 \circ$ & 4 & 243.6 & -35.5 & 2.4 & 300 & 450 & -32.4 & 10.5 & 144.5 \\
\hline EX275 & $232.3 \circ$ & 4 & 231.9 & -13.2 & 2.7 & 300 & 450 & -34.2 & 31 & 139.8 \\
\hline EX274 & $232.4 \circ$ & 4 & 232 & -52 & 4.5 & 300 & 450 & -47.5 & 1.3 & 154.7 \\
\hline EX281 & 241.60 & 4 & 243.4 & -22.5 & 7.4 & 300 & 450 & -28.3 & 18.3 & 138.2 \\
\hline EX283 & 241.80 & 4 & 238.1 & -26.9 & 3.3 & 300 & 450 & -33.9 & 19.4 & 144.6 \\
\hline EX285 & 2420 & 4 & 227.2 & -16.8 & 1.7 & 300 & 450 & -38.9 & 33 & 145.5 \\
\hline EX289 & 248.30 & 4 & 231.1 & -18.6 & 5.9 & 300 & 450 & -36.6 & 28.9 & 144.3 \\
\hline EX293 & $253.5 \circ$ & 4 & 45.6 & 27.4 & 1.5 & 300 & 450 & 43.9 & 208.2 & 26 \\
\hline EX294 & $253.8 \circ$ & 4 & 61.4 & 41.6 & 3.3 & 300 & 450 & 36.4 & 187.3 & 31.9 \\
\hline EX296 & $258 \circ$ & 4 & 47 & 25.4 & 10.3 & 300 & 450 & 42.1 & 208.3 & 28.3 \\
\hline EX300 & 278.10 & 4 & 229 & -52.4 & 1.2 & 300 & 450 & -50 & 2.1 & 156.4 \\
\hline EX301 & $278.4 \circ$ & 4 & 240.8 & -34.7 & 2.4 & 300 & 450 & -34.4 & 12.7 & 146.4 \\
\hline EX303 & 279.60 & 4 & 219.7 & -22.6 & 0.7 & 300 & 450 & -46.6 & 36.4 & 154.4 \\
\hline EX311 & $283.8 \circ$ & 4 & 251.8 & -35.6 & 2 & 300 & 450 & -25.9 & 5.9 & 138.5 \\
\hline EX312 & $284 \circ$ & 4 & 247.5 & -30.3 & 3.9 & 300 & 450 & -27.5 & 11.5 & 139.3 \\
\hline EX314 & 288.10 & 4 & 64.4 & 40.3 & 1.5 & 300 & 450 & 33.5 & 186.6 & 34.4 \\
\hline EX317 & 291.80 & 4 & 73.3 & 68.5 & 2.1 & 300 & 450 & 37.7 & 150.3 & 39.7 \\
\hline EX319 & 292.60 & 4 & 34.5 & 22.2 & 5.9 & 300 & 450 & 50.2 & 221.9 & 23.1 \\
\hline EX321 & 292.80 & 4 & 19 & 72.2 & 3.5 & 300 & 450 & 65.8 & 127.4 & 31.2 \\
\hline EX323 & 294.80 & 4 & 50.9 & 30.2 & 1.4 & 300 & 450 & 40.8 & 202.3 & 28.2 \\
\hline EX325 & $295.8 \circ$ & 4 & 50 & 47.7 & 2.1 & 300 & 450 & 47.7 & 187.5 & 23.3 \\
\hline EX327 & 2970 & 4 & 50.9 & 27.4 & 2.2 & 300 & 450 & 39.8 & 204.1 & 29.8 \\
\hline EX329 & 297.50 & 4 & 47.2 & 61.4 & 1.7 & 300 & 450 & 53.6 & 167.6 & 26.8 \\
\hline NX1.1 & 2980 & 4 & 62.7 & 26.3 & 2.8 & 300 & 450 & 30 & 196.7 & 39.2 \\
\hline NX4.2 & 3340 & 4 & 236.7 & -30.8 & 2.7 & 300 & 450 & -36.3 & 17.9 & 147.7 \\
\hline NX6.1 & 3460 & 4 & 196.8 & -27.5 & 0.5 & 300 & 450 & -63.4 & 63.2 & 166.5 \\
\hline NX7.2 & $358 \circ$ & 4 & 46.9 & 44.6 & 2.9 & 300 & 450 & 49.1 & 192.8 & 21 \\
\hline NX9.1 & 370 o & 4 & -18.6 & 66.2 & 4.3 & 300 & 450 & 71.9 & 59.1 & 32.5 \\
\hline NX10.1 & 3710 & 4 & 15 & 39.8 & 2.2 & 300 & 450 & 71 & 234.9 & 2.9 \\
\hline NX11.2 & $375.5 \circ$ & 4 & 26.9 & 45.5 & 3.7 & 300 & 450 & 65.3 & 207.1 & 7.6 \\
\hline NX12.1 & 3780 & 4 & 33.3 & 37.8 & 4.9 & 300 & 450 & 57.3 & 210.7 & 11.8 \\
\hline \multicolumn{11}{|c|}{45 cutoff } \\
\hline EX1 & 0.60 & 4 & 230.8 & 7 & 3.3 & 300 & 450 & -28.1 & 40.7 & 123.6 \\
\hline EX3 & 2.20 & 4 & -86.6 & 12.8 & 6.7 & 300 & 450 & 6.6 & 15.1 & 92.7 \\
\hline EX7 & $4.4 \circ$ & 4 & -80.4 & 3.1 & 6.7 & 300 & 450 & 8.6 & 7.4 & 94.7 \\
\hline EX9 & 5.40 & 4 & 248.4 & 4.5 & 6.6 & 300 & 450 & -15.8 & 27 & 115.6 \\
\hline EX15 & $13.7 \circ$ & 4 & -75.7 & -13 & 7.8 & 300 & 450 & 7.4 & 358 & 101.6 \\
\hline EX16 & $14.2 \circ$ & 4 & 267.8 & 30.8 & 6.4 & 300 & 450 & 8.1 & 26.6 & 83.9 \\
\hline EX17 & $15.3 \circ$ & 4 & 256.9 & -1.9 & 7.5 & 300 & 450 & -11.1 & 19 & 114.6 \\
\hline EX18 & $17 \circ$ & 4 & 267.8 & 28.3 & 3.4 & 300 & 450 & 7.2 & 25.4 & 85.6 \\
\hline EX19 & $18.3 \circ$ & 4 & 216.8 & 5.4 & 9.2 & 300 & 450 & -37.9 & 52.6 & 130.7 \\
\hline EX35 & 470 & 4 & 237.4 & -5.5 & 1.2 & 300 & 450 & -27.4 & 30.4 & 130.4 \\
\hline EX37 & 47.6 o & 4 & 236.5 & -6.1 & 9.9 & 300 & 450 & -28.3 & 30.8 & 131.4 \\
\hline EX43 & 49.4 o & 4 & 241 & -14.3 & 1.8 & 300 & 450 & -27.5 & 24 & 134.5 \\
\hline EX51 & 52.50 & 4 & 242.5 & -2.2 & 3 & 300 & 450 & -22.5 & 28.3 & 124.6 \\
\hline EX52 & 530 & 4 & -88.4 & -18.9 & 3.9 & 300 & 450 & -4.5 & 3.1 & 114.8 \\
\hline EX67 & $62.9 \circ$ & 4 & 236.6 & -0.4 & 3.6 & 300 & 450 & -26.4 & 33.2 & 126.8 \\
\hline EX71 & $65 \circ$ & 4 & 253.6 & 8.3 & 2.3 & 300 & 450 & -10.6 & 25.2 & 109.4 \\
\hline EX072 & $65.6 \circ$ & 4 & 264.2 & -28.5 & 3.8 & 300 & 450 & -13.5 & 2.9 & 125.8 \\
\hline EX094 & $78.4 \circ$ & 4 & -81.8 & -42.7 & 2.8 & 300 & 450 & -8.4 & 347.2 & 123 \\
\hline EX95 & $79.2 \circ$ & 4 & 259.1 & -4.9 & 5.9 & 300 & 450 & -10.2 & 16.4 & 115.2 \\
\hline EX97 & 81.7 o & 4 & 253 & -25.5 & 3.1 & 300 & 450 & -21.5 & 10.9 & 132.7 \\
\hline EX98 & 82.60 & 4 & 244.4 & -17.4 & 4.6 & 300 & 450 & -25.8 & 20.2 & 134.2 \\
\hline EX099 & $82.7 \circ$ & 6 & 229.8 & -1.2 & 11 & 300 & 450 & -31.6 & 38.1 & 131.1 \\
\hline EX101 & $83.4 \circ$ & 4 & 260.1 & -10.7 & 4.3 & 300 & 450 & -11.2 & 13.5 & 118.4 \\
\hline EX102 & 83.80 & 4 & 254.9 & -2.4 & 2.1 & 300 & 450 & -12.8 & 20.1 & 116.4 \\
\hline EX103 & 84.20 & 4 & 251.6 & -18.9 & 4 & 300 & 450 & -20.6 & 15 & 129.9 \\
\hline EX104 & 84.80 & 4 & -75.9 & -64.5 & 5.9 & 300 & 450 & -17.2 & 326.5 & 128.1 \\
\hline EX105 & 850 & 4 & -78.6 & 13.5 & 2.5 & 300 & 450 & 13.2 & 10.6 & 86.5 \\
\hline EX106 & $85.6 \circ$ & 4 & 239.5 & -8.3 & 3.8 & 300 & 450 & -26.7 & 27.7 & 131.1 \\
\hline EX110 & 89.6 o & 4 & 54.5 & -3.3 & 1.7 & 300 & 450 & 26.7 & 216.3 & 55.1 \\
\hline EX111 & 90.10 & 4 & 83.5 & 33.5 & 1.9 & 300 & 450 & 15.9 & 180.6 & 51.1 \\
\hline EX112 & 90.8 o & 4 & 75.2 & 19.8 & 0.9 & 300 & 450 & 17.9 & 192.3 & 52.3 \\
\hline EX114 & $92.2 \circ$ & 4 & 92.7 & 58.8 & 3.8 & 300 & 450 & 20.5 & 157.2 & 48.1 \\
\hline EX116 & $93.6 \circ$ & 4 & 76.6 & 23.4 & 7.7 & 300 & 450 & 18 & 189.8 & 51.2 \\
\hline
\end{tabular}




\begin{tabular}{|c|c|c|c|c|c|c|c|c|c|c|}
\hline EX117 & $93.8 \circ$ & 4 & 80.9 & 30.7 & 7.8 & 300 & 450 & 16.9 & 183.6 & 50.6 \\
\hline EX119 & 94.6 o & 4 & -87 & 0.7 & 10.3 & 300 & 450 & 2.6 & 10.4 & 101.2 \\
\hline EX120 & 95.60 & 4 & 246.4 & -9.9 & 6 & 300 & 450 & -21.8 & 22.3 & 127.7 \\
\hline EX122 & 980 & 4 & 257.4 & 17.3 & 2.6 & 300 & 450 & -4.7 & 26.6 & 100.3 \\
\hline EX124 & 99.40 & 4 & 254.1 & -25.4 & 6.4 & 300 & 450 & -20.6 & 10.3 & 131.8 \\
\hline EX125 & 99.7 o & 4 & 249.5 & -0.5 & 4.7 & 300 & 450 & -16.5 & 24.2 & 118.8 \\
\hline EX131 & $104.6 \circ$ & 4 & 92.3 & 42.9 & 2.1 & 300 & 450 & 12.8 & 170.2 & 53.1 \\
\hline EX133 & 105.9 o & 4 & 63.2 & 13.2 & 2.6 & 300 & 450 & 25.4 & 203 & 47.7 \\
\hline EX151 & $122.6 \circ$ & 4 & 156.6 & -11 & 8.7 & 300 & 450 & -52.3 & 142.2 & 132.6 \\
\hline EX153 & 124 o & 4 & 250.2 & -13.8 & 1.8 & 300 & 450 & -20.1 & 18.2 & 127.7 \\
\hline EX157 & 127 o & 4 & 266.3 & -36.4 & 1.8 & 300 & 450 & -14.7 & 357.4 & 128.2 \\
\hline EX165 & $132.9 \circ$ & 4 & 234.9 & -8.1 & 4.4 & 300 & 450 & -30.2 & 31.1 & 133.9 \\
\hline EX173 & 139 o & 4 & 236.1 & -3.3 & 4.6 & 300 & 450 & -27.7 & 32.3 & 129.4 \\
\hline EX181 & 144.5 o & 4 & 246.9 & -11.9 & 10.4 & 300 & 450 & -22.1 & 21.1 & 128.7 \\
\hline EX183 & 145.7 o & 4 & 251.1 & -8 & 3.3 & 300 & 450 & -17.6 & 20.1 & 123.1 \\
\hline EX189 & 151.4 o & 4 & 241.5 & -6.9 & 3.1 & 300 & 450 & -24.7 & 26.9 & 128.8 \\
\hline EX191 & 152.6 o & 4 & 238.8 & -2.8 & 8.2 & 300 & 450 & -25.5 & 30.6 & 127.4 \\
\hline EX193 & 154.20 & 4 & 250.5 & -6.2 & 5 & 300 & 450 & -17.5 & 21.3 & 122.2 \\
\hline EX195 & 155.6 o & 4 & -84.8 & -3 & 3.9 & 300 & 450 & 3.3 & 7.6 & 102 \\
\hline EX197 & 156.8 o & 4 & 264.5 & -16.9 & 3.3 & 300 & 450 & -9.5 & 8.2 & 119 \\
\hline EX247 & 192.1 o & 4 & 97.2 & 27.2 & 3 & 300 & 450 & 2.9 & 176.1 & 64.5 \\
\hline EX264 & 215.8 o & 4 & 90.4 & 71.1 & 4 & 300 & 450 & 29.2 & 142.3 & 45.8 \\
\hline EX265 & 216.7 o & 4 & -36.6 & -52.8 & 2.8 & 300 & 450 & 12.2 & 312.5 & 105.1 \\
\hline EX267 & 220.3 o & 4 & 266.3 & -10.1 & 4.7 & 300 & 450 & -6 & 10 & 113.3 \\
\hline EX268 & 220.60 & 4 & 256.1 & -31.5 & 5.4 & 300 & 450 & -21.1 & 5.8 & 133.5 \\
\hline EX270 & 223.10 & 4 & 246.8 & 1.6 & 9.6 & 300 & 450 & -18 & 26.9 & 119 \\
\hline EX276 & $233.5 \circ$ & 4 & 266.2 & -32.5 & 3.6 & 300 & 450 & -13.4 & 359.7 & 126.4 \\
\hline EX280 & $240.3 \circ$ & 4 & 100.1 & 51.4 & 7.6 & 300 & 450 & 11.4 & 160.2 & 54.4 \\
\hline EX287 & 2450 & 4 & 254.6 & 6.8 & 4.4 & 300 & 450 & -10.3 & 24 & 109.9 \\
\hline EX288 & 245.50 & 4 & -89.7 & -6.7 & 10.3 & 300 & 450 & -1.8 & 9 & 108.1 \\
\hline EX291 & $248.8 \circ$ & 4 & 264.6 & -5.7 & 7.5 & 300 & 450 & -6 & 12.8 & 111.7 \\
\hline EX307 & $281.6 \circ$ & 5 & -88.8 & -29.1 & 7.4 & 300 & 450 & -8.2 & 358.6 & 121 \\
\hline EX309 & $282.9 \circ$ & 4 & 251.8 & -27.6 & 2.1 & 300 & 450 & -23.2 & 10.5 & 134.7 \\
\hline EX313 & 285.4 o & 5 & 258.8 & -4.1 & 4.1 & 300 & 450 & -10.2 & 17 & 114.8 \\
\hline EX315 & 2910 & 4 & 82 & 31.1 & 2 & 300 & 450 & 16.2 & 182.7 & 51.2 \\
\hline EX331 & 297.7 o & 4 & 79.2 & 11.6 & 6 & 300 & 450 & 12.2 & 193.6 & 60.4 \\
\hline NX5.2 & $338.5 \circ$ & 4 & -89.7 & -58.6 & 3.3 & 300 & 450 & -22 & 338.5 & 133.1 \\
\hline
\end{tabular}




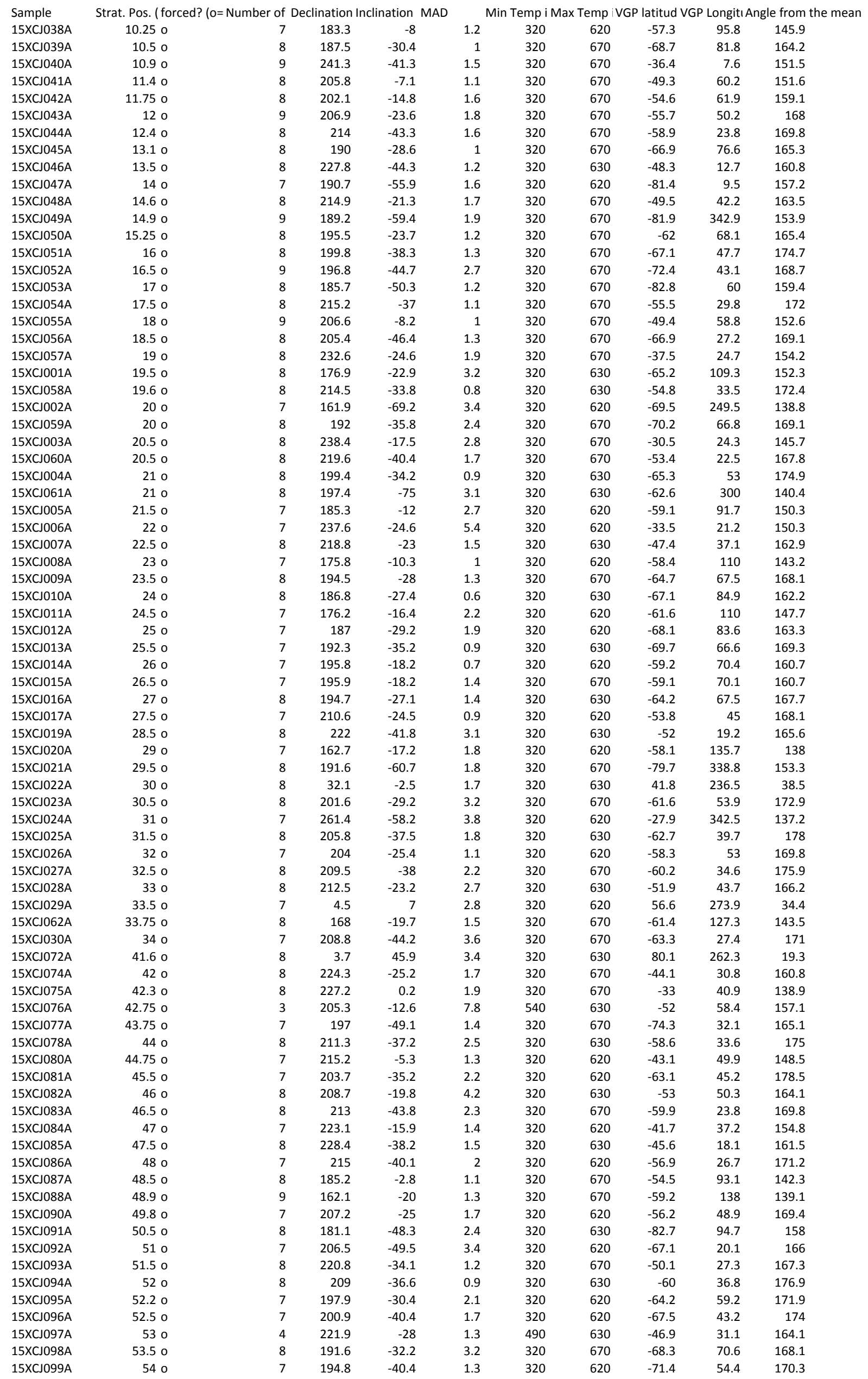




\begin{tabular}{|c|c|c|c|c|c|c|c|c|c|c|}
\hline $15 X \mathrm{XJ} 100 \mathrm{~A}$ & $54.5 \circ$ & 8 & 202.8 & -44.7 & 2.2 & 320 & 630 & -68.1 & 33.5 & 170.5 \\
\hline $15 X C J 101 \mathrm{~A}$ & 550 & 7 & 197.8 & -49.8 & 1.8 & 320 & 620 & -74 & 28.8 & 164.7 \\
\hline $15 X \mathrm{XJ} 102 \mathrm{~A}$ & $55.5 \circ$ & 7 & 4.5 & 32.4 & 2.2 & 320 & 620 & 70.6 & 269 & 17.6 \\
\hline $15 X \mathrm{XJ} 103 \mathrm{~A}$ & 56.10 & 8 & 35.8 & 47.2 & 4.2 & 320 & 630 & 58.9 & 196.8 & 14.1 \\
\hline $15 \times C J 104 A$ & $56.5 \circ$ & 7 & 40.9 & 43.4 & 2.3 & 320 & 620 & 53.5 & 198.1 & 14.3 \\
\hline $15 \times C J 105 A$ & 570 & 8 & 9 & 40.5 & 1.1 & 320 & 670 & 74.5 & 249.6 & 13.9 \\
\hline $15 X \mathrm{XJ} 106 \mathrm{~A}$ & $57.3 \circ$ & 8 & 20.9 & 38.2 & 1.6 & 320 & 630 & 66.4 & 226.2 & 4.5 \\
\hline 15XCJ107A & 57.90 & 7 & 19.7 & 42.7 & 2.2 & 320 & 620 & 69.4 & 221.5 & 8.5 \\
\hline $15 X \mathrm{XJ} 108 \mathrm{~A}$ & $58.5 \circ$ & 7 & 17.4 & 53.1 & 2 & 320 & 620 & 75.4 & 198.7 & 18.4 \\
\hline 15XCJ109A & 58.9 o & 8 & 12.7 & 25.7 & 2.6 & 320 & 630 & 64.3 & 252.5 & 14.7 \\
\hline $15 \times C J 110 \mathrm{~A}$ & $59.5 \circ$ & 7 & 31.4 & 26.5 & 5.9 & 320 & 620 & 54 & 222.7 & 10.4 \\
\hline $15 X \mathrm{XJ} 112 \mathrm{~A}$ & $60.25 \circ$ & 9 & 178.2 & -31 & 2.5 & 320 & 670 & -70.1 & 106.9 & 156.9 \\
\hline $15 X C J 113 A$ & 610 & 7 & 226 & -32.7 & 4.4 & 320 & 620 & -45.5 & 24.3 & 162.7 \\
\hline $15 X \mathrm{XJ} 114 \mathrm{~A}$ & $61.5 \circ$ & 8 & 227.1 & -53.9 & 2.2 & 320 & 670 & -52 & 0.8 & 156.2 \\
\hline $15 X \mathrm{XJ} 115 \mathrm{~A}$ & $62 \circ$ & 8 & 234.4 & -69.4 & 2 & 320 & 630 & -49.3 & 330.3 & 142.5 \\
\hline $15 X \mathrm{XJ} 116 \mathrm{~A}$ & $62.3 \circ$ & 8 & 184.2 & -35.9 & 2.5 & 320 & 670 & -72.9 & 88.3 & 162.8 \\
\hline $15 X \mathrm{XJ} 117 \mathrm{~A}$ & $63 \circ$ & 8 & 201 & -21.8 & 2.1 & 320 & 670 & -58.4 & 59.9 & 165.8 \\
\hline $15 X \mathrm{XJ} 118 \mathrm{~A}$ & 63.50 & 3 & 246 & -48.9 & 10.1 & 540 & 630 & -35.5 & 358.7 & 147.6 \\
\hline 15XCJ119A & 640 & 7 & 175.9 & -46.8 & 2.6 & 320 & 620 & -80.8 & 125.3 & 155.3 \\
\hline $15 X \mathrm{XJ} 120 \mathrm{~A}$ & $64.5 \circ$ & 8 & 202.4 & -15.5 & 1.8 & 320 & 670 & -54.8 & 61.1 & 159.9 \\
\hline $15 X \mathrm{XJ} 121 \mathrm{~A}$ & $65 \circ$ & 9 & 175 & -36.9 & 2.6 & 320 & 630 & -73.4 & 118.4 & 155.6 \\
\hline $15 X \mathrm{XJ} 122 \mathrm{~A}$ & $65.7 \circ$ & 8 & 195.1 & -25.6 & 1.8 & 320 & 670 & -63.2 & 67.8 & 166.7 \\
\hline $15 X \mathrm{XJ} 123 \mathrm{~A}$ & 660 & 8 & 173.8 & -44 & 2.1 & 320 & 670 & -77.9 & 129.5 & 154.5 \\
\hline $15 X \mathrm{XJ} 124 \mathrm{~A}$ & $66.5 \circ$ & 4 & 212.2 & -27 & 11.1 & 490 & 630 & -53.6 & 41.4 & 169.7 \\
\hline $15 X \mathrm{XJ} 125 \mathrm{~A}$ & 670 & 8 & 196 & -28.4 & 2.1 & 320 & 670 & -64.2 & 64.2 & 169.4 \\
\hline $15 X \mathrm{XJ} 126 \mathrm{~A}$ & 67.7 o & 7 & -18.9 & 17.5 & 8.5 & 320 & 620 & 57.5 & 318.4 & 43.1 \\
\hline $15 X \mathrm{CJ} 127 \mathrm{~A}$ & 680 & 8 & 38.3 & 40.7 & 3.9 & 320 & 630 & 54.5 & 203.2 & 11.4 \\
\hline $15 X \mathrm{XJ} 128 \mathrm{~A}$ & 68.50 & 6 & 7.1 & 36.8 & 1.6 & 370 & 620 & 72.7 & 258.9 & 14.8 \\
\hline $15 X \mathrm{XJ} 129 \mathrm{~A}$ & 690 & 8 & 41.9 & 26.2 & 3.4 & 320 & 670 & 46.3 & 212.2 & 16.9 \\
\hline $15 X \mathrm{XJ} 130 \mathrm{~A}$ & $69.5 \circ$ & 8 & 25.2 & 26.4 & 1.8 & 320 & 630 & 58.1 & 230.7 & 9.1 \\
\hline $15 \times C J 131 \mathrm{~A}$ & 70 o & 7 & 42.8 & 68.6 & 5.6 & 320 & 620 & 56.4 & 151.3 & 34.5 \\
\hline $15 X \mathrm{XJ} 132 \mathrm{~A}$ & 70.5 o & 7 & 15.2 & 30.5 & 3.6 & 320 & 620 & 65.7 & 244.3 & 9.9 \\
\hline $15 X \mathrm{XJ} 133 \mathrm{~A}$ & 710 & 8 & 6.9 & 33.9 & 1.4 & 320 & 630 & 71 & 261.4 & 15.2 \\
\hline $15 X \mathrm{XJ} 134 \mathrm{~A}$ & 71.5 o & 7 & 30.2 & 22.9 & 2.5 & 320 & 620 & 53.3 & 226.4 & 13.3 \\
\hline $15 X \mathrm{XJ} 135 \mathrm{~A}$ & 720 & 8 & 43.1 & 12.9 & 3.4 & 320 & 670 & 40.5 & 218.7 & 27.7 \\
\hline $15 X \mathrm{XJ} 137 \mathrm{~A}$ & 730 & 7 & -4.4 & 11.7 & 2.2 & 320 & 620 & 59 & 290.6 & 36 \\
\hline $15 X \mathrm{XJ} 138 \mathrm{~A}$ & 73.5 o & 7 & 30 & 23.5 & 2.5 & 320 & 620 & 53.7 & 226.4 & 12.6 \\
\hline $15 X \mathrm{XJ} 139 \mathrm{~A}$ & 740 & 8 & 53.4 & 18.9 & 3.2 & 320 & 630 & 34.9 & 207.2 & 29.7 \\
\hline $15 X \mathrm{XJ} 142 \mathrm{~A}$ & 75.5 o & 9 & 15.9 & 20.5 & 4.1 & 320 & 670 & 60.3 & 249.1 & 17.2 \\
\hline $15 \times C J 147 A$ & $78 \circ$ & 7 & 7 & 22.3 & 7.1 & 320 & 620 & 64.2 & 266 & 20.7 \\
\hline $15 X \mathrm{XJ} 148 \mathrm{~A}$ & $78.5 \circ$ & 8 & 17.3 & 10.6 & 3.8 & 320 & 670 & 55 & 250.9 & 25.9 \\
\hline $15 X \mathrm{XJ} 149 \mathrm{~A}$ & 79 o & 8 & -4.9 & 17.7 & 3.1 & 320 & 630 & 62.1 & 292.4 & 32.2 \\
\hline $15 X \mathrm{XJ} 151 \mathrm{~A}$ & 800 & 7 & -10.4 & 36.1 & 3.7 & 320 & 620 & 71.1 & 313.6 & 28.9 \\
\hline $15 X \mathrm{XJ} 152 \mathrm{~A}$ & 80.50 & 7 & 3.2 & 30.5 & 3.7 & 320 & 620 & 69.6 & 273 & 19.2 \\
\hline $15 X \mathrm{XJ} 153 \mathrm{~A}$ & 810 & 9 & -0.8 & 56.6 & 4 & 320 & 670 & 89.1 & 53 & 27.5 \\
\hline 15XCJ154A & 81.50 & 8 & 25.9 & 48 & 2.3 & 320 & 670 & 67.1 & 203.8 & 12.5 \\
\hline $15 X \mathrm{XJ} 157 \mathrm{~A}$ & 82.450 & 8 & 54.3 & 22.4 & 5 & 320 & 670 & 35.4 & 204.6 & 28.3 \\
\hline $15 X C J 156 \mathrm{~A}$ & $82.55 \circ$ & 9 & 10.3 & 15.3 & 1.4 & 320 & 670 & 59.7 & 261.5 & 24.3 \\
\hline $15 X \mathrm{XJ} 158 \mathrm{~A}$ & $83 \circ$ & 8 & -28.8 & 43.3 & 3.1 & 320 & 670 & 63 & 355.3 & 41.8 \\
\hline 15XCJ159A & 83.50 & 8 & -14.1 & 61.5 & 3.7 & 320 & 630 & 77.6 & 45.4 & 35.9 \\
\hline $15 X \mathrm{XJ} 160 \mathrm{~A}$ & 83.950 & 8 & 4.9 & 49.7 & 2.3 & 320 & 670 & 82.7 & 247.1 & 20.6 \\
\hline $15 X \mathrm{XJ} 162 \mathrm{~A}$ & 85.05 o & 9 & 194.4 & -29.9 & 3.5 & 320 & 670 & -65.7 & 66.3 & 169.2 \\
\hline $15 X \mathrm{XJ} 163 \mathrm{~A}$ & $85.5 \circ$ & 8 & 233.7 & -22.9 & 2.7 & 320 & 670 & -36.1 & 24.8 & 152.4 \\
\hline $15 X \mathrm{XJ} 164 \mathrm{~A}$ & 860 & 3 & 220.7 & -55.3 & 6.6 & 570 & 670 & -57.4 & 0.8 & 157.6 \\
\hline $15 X \mathrm{XJ} 165 \mathrm{~A}$ & 86.50 & 9 & 244.8 & -39.7 & 2.5 & 320 & 670 & -33 & 7 & 148.8 \\
\hline $15 X C J 166 \mathrm{~A}$ & 870 & 8 & 210.5 & -42.4 & 3.1 & 320 & 670 & -61.3 & 28.2 & 172.1 \\
\hline $15 X \mathrm{XJ} 167 \mathrm{~A}$ & 87.50 & 8 & 229.7 & -40.6 & 2.4 & 320 & 670 & -45.4 & 15.1 & 160.3 \\
\hline $15 X \mathrm{XJ} 168 \mathrm{~A}$ & 87.98 o & 9 & 211.5 & -45.5 & 4.3 & 320 & 670 & -61.7 & 22.8 & 169 \\
\hline 15XCJ169A & 88.450 & 8 & 229.7 & -28.7 & 5.8 & 320 & 670 & -41.2 & 24.2 & 158.4 \\
\hline $15 \times \mathrm{XJ} 170 \mathrm{~A}$ & $89 \circ$ & 8 & 199.1 & -23.5 & 1.9 & 320 & 670 & -60.2 & 61.9 & 166.8 \\
\hline $15 X \mathrm{XJ} 171 \mathrm{~A}$ & 89.40 & 9 & 218.5 & -26.2 & 3.3 & 320 & 670 & -48.8 & 35.4 & 165.5 \\
\hline $15 X \mathrm{XJ} 172 \mathrm{~A}$ & 90.02 o & 8 & 211.2 & -37.4 & 1.9 & 320 & 670 & -58.7 & 33.4 & 175 \\
\hline $15 X \mathrm{XJ} 173 \mathrm{~A}$ & 90.45 o & 8 & 239.7 & -47 & 2.9 & 320 & 670 & -39.7 & 3.5 & 152.1 \\
\hline $15 X \mathrm{XJ} 174 \mathrm{~A}$ & 90.97 o & 9 & 189.5 & -48.5 & 2 & 320 & 670 & -79.3 & 51.2 & 162.5 \\
\hline $15 \times C J 175 A$ & $91.5 \circ$ & 8 & 193.7 & -46.1 & 1.5 & 320 & 670 & -75.2 & 46.7 & 166.2 \\
\hline $15 X \mathrm{XJ} 176 \mathrm{~A}$ & $92 \circ$ & 8 & 199.1 & -40.5 & 1.3 & 320 & 670 & -68.7 & 46 & 172.9 \\
\hline 15XCJ177A & $92.4 \circ$ & 9 & 197.2 & -34.8 & 2.2 & 320 & 670 & -67 & 56.6 & 173.2 \\
\hline $15 X \mathrm{XJ} 178 \mathrm{~A}$ & 930 & 8 & 241.8 & -44.8 & 3.4 & 320 & 670 & -37.2 & 4.4 & 150.9 \\
\hline 15XCJ179A & 93.45 o & 8 & 229.3 & -21.6 & 1.4 & 320 & 670 & -39 & 28.9 & 154.9 \\
\hline $15 X C J 180 \mathrm{~A}$ & $94.03 \circ$ & 9 & 219.1 & -25.2 & 1.3 & 320 & 670 & -47.9 & 35.4 & 164.3 \\
\hline $15 X \mathrm{XJ} 181 \mathrm{~A}$ & $94.5 \circ$ & 8 & 214.3 & -38.4 & 1.2 & 320 & 670 & -56.7 & 29.2 & 172.3 \\
\hline $15 X \mathrm{XJ} 182 \mathrm{~A}$ & $95 \circ$ & 8 & 209.8 & -30.2 & 1.5 & 320 & 670 & -56.7 & 41.7 & 173.5 \\
\hline $15 X \mathrm{XJ} 183 \mathrm{~A}$ & $95.5 \circ$ & 9 & 228.5 & -46 & 1.9 & 320 & 670 & -48.3 & 10.4 & 159.7 \\
\hline $15 X \mathrm{XJ} 184 \mathrm{~A}$ & $96 \circ$ & 8 & 187.8 & -35.8 & 2.7 & 320 & 670 & -71.9 & 77.7 & 165.7 \\
\hline $15 X \mathrm{XJ} 185 \mathrm{~A}$ & 96.5 o & 8 & 211 & -47.6 & 1.5 & 320 & 670 & -62.9 & 20 & 167.2 \\
\hline $15 X \mathrm{XJ} 186 \mathrm{~A}$ & 97 o & 8 & 210.4 & -40.7 & 1 & 320 & 670 & -60.6 & 30.5 & 173.5 \\
\hline $15 X \mathrm{XJ} 187 \mathrm{~A}$ & $97.5 \circ$ & 8 & 190.3 & -24.6 & 1.8 & 320 & 670 & -64.5 & 78.2 & 163 \\
\hline $15 X C J 189 A$ & $98.5 \circ$ & 7 & 177.1 & -31.2 & 0.9 & 320 & 630 & -70 & 110.1 & 156.1 \\
\hline $15 X \mathrm{XJ} 190 \mathrm{~A}$ & 99 o & 7 & 215.4 & -63.5 & 1.5 & 320 & 620 & -62.2 & 343.2 & 151.3 \\
\hline $15 X \mathrm{XJ} 191 \mathrm{~A}$ & 99.5 o & 7 & 227.1 & -31.9 & 3 & 320 & 620 & -44.4 & 24 & 161.7 \\
\hline
\end{tabular}




\begin{tabular}{|c|c|c|c|c|c|c|c|c|c|c|}
\hline $15 X C J 192 A$ & $100 \circ$ & 8 & 217.1 & -34.9 & 2.5 & 320 & 630 & -53.2 & 29.9 & 170.4 \\
\hline 15XCJ194A & 101 o & 8 & 222.7 & -12.1 & 1.1 & 320 & 670 & -40.6 & 39.4 & 151.9 \\
\hline 15XCJ195A & 101.5 o & 8 & 216.8 & -26.7 & 1.5 & 320 & 630 & -50.3 & 36.7 & 166.9 \\
\hline 15XCJ196A & 102 o & 8 & 214.4 & -17.8 & 3.6 & 320 & 670 & -48.5 & 44.7 & 160.6 \\
\hline 15XCJ197A & 102.5 o & 8 & 227.6 & -9.6 & 1.7 & 320 & 670 & -36.2 & 36.3 & 147.2 \\
\hline 15XCJ198A & 103 o & 9 & 208.9 & -21.8 & 1.3 & 320 & 670 & -53.7 & 48.8 & 166 \\
\hline 15XCJ199A & 103.5 o & 8 & 189.2 & -22.5 & 1.9 & 320 & 670 & -63.7 & 81.3 & 160.8 \\
\hline $15 X \mathrm{XJ} 200 \mathrm{~A}$ & 104 o & 8 & 202.5 & -45.3 & 3.2 & 320 & 670 & -68.6 & 32.8 & 169.9 \\
\hline $15 \times C J 201 \mathrm{~A}$ & $104.5 \circ$ & 4 & 230.8 & -47.5 & 5.3 & 540 & 670 & -47 & 7.5 & 157.7 \\
\hline $15 X C J 202 \mathrm{~A}$ & 105 o & 8 & 206.6 & -21.1 & 3.6 & 320 & 670 & -54.9 & 52.2 & 165.6 \\
\hline $15 X C J 203 \mathrm{~A}$ & 105.5 o & 4 & 148.2 & -41.8 & 7.7 & 470 & 620 & -60 & 176.4 & 135.7 \\
\hline $15 X C J 204 \mathrm{~A}$ & $106 \circ$ & 9 & 219.9 & -30 & 5.8 & 320 & 670 & -49.2 & 31.4 & 166.7 \\
\hline $15 X C J 205 A$ & 106.5 o & 7 & 201.3 & -22.1 & 5 & 320 & 670 & -58.4 & 59.2 & 166.1 \\
\hline $15 X \mathrm{XJ} 206 \mathrm{~A}$ & 107 o & 8 & 179.3 & -10 & 3.9 & 320 & 670 & -58.4 & 103.3 & 145.2 \\
\hline $15 X C J 207 \mathrm{~A}$ & 107.5 o & 9 & 192.3 & -20 & 4.2 & 320 & 670 & -61.5 & 76 & 160.7 \\
\hline $15 X C J 208 \mathrm{~A}$ & 108 o & 8 & 175.2 & -34.3 & 2.8 & 320 & 670 & -71.7 & 116.6 & 155.3 \\
\hline $15 X C J 209 A$ & $108.5 \circ$ & 8 & 213.6 & -40.3 & 4.1 & 320 & 670 & -58 & 27.7 & 171.9 \\
\hline $15 X C J 210 \mathrm{~A}$ & 109 o & 9 & 231.8 & -33.7 & 4.4 & 320 & 670 & -41.3 & 19.4 & 158.3 \\
\hline $15 \times C J 211 \mathrm{~A}$ & 109.5 o & 8 & 184.7 & -38.6 & 3 & 320 & 670 & -74.6 & 85.2 & 163.3 \\
\hline $15 X \mathrm{XJ} 213 \mathrm{~A}$ & 110.5 o & 8 & 246.7 & -25.4 & 1.6 & 320 & 670 & -26.5 & 14.8 & 143.3 \\
\hline $15 \times C J 214 \mathrm{~A}$ & 111 o & 8 & 148.5 & -46.2 & 5 & 320 & 670 & -62 & 182.2 & 136.6 \\
\hline $15 \mathrm{XCJ} 215 \mathrm{~A}$ & 111.5 o & 8 & 234 & -47.7 & 3 & 320 & 670 & -44.5 & 5.6 & 155.6 \\
\hline $15 X C J 216 \mathrm{~A}$ & $112 \circ$ & 9 & 235.8 & -34.1 & 5 & 320 & 670 & -38.2 & 16.4 & 155.1 \\
\hline $15 \times C J 217 \mathrm{~A}$ & 112.5 o & 8 & 213.6 & -36.6 & 6.3 & 320 & 670 & -56.6 & 31.8 & 173.3 \\
\hline $15 X \mathrm{XJ} 218 \mathrm{~A}$ & 113 o & 8 & 218 & -25.9 & 2.1 & 320 & 670 & -49.1 & 36.1 & 165.6 \\
\hline $15 \times C J 219 A$ & 113.4 o & 9 & 182 & -31.7 & 2.8 & 320 & 670 & -70.5 & 96.3 & 160.2 \\
\hline $15 \times C J 220 \mathrm{~A}$ & 114 o & 8 & 196.1 & -38.1 & 1.9 & 320 & 670 & -69.3 & 55.1 & 172.1 \\
\hline $15 X C J 221 \mathrm{~A}$ & 114.5 o & 8 & 211.5 & -6 & 8 & 320 & 670 & -45.6 & 53.8 & 149.9 \\
\hline $15 X C J 222 \mathrm{~A}$ & $115 \circ$ & 9 & 203.5 & -43.1 & 4.1 & 320 & 670 & -66.8 & 35.2 & 172.3 \\
\hline $15 X \mathrm{XJ} 223 \mathrm{~A}$ & 115.5 o & 8 & 231.5 & -41.6 & 7.4 & 320 & 670 & -44.3 & 13.1 & 158.8 \\
\hline $15 X \mathrm{XJ} 225 \mathrm{~A}$ & 115.9 o & 9 & 209.8 & -45.6 & 7.1 & 320 & 670 & -63.1 & 24.2 & 169.4 \\
\hline $15 \times C J 226 \mathrm{~A}$ & 116.5 o & 8 & 206.9 & -61.6 & 5.4 & 320 & 670 & -68.6 & 347.1 & 153.9 \\
\hline $15 X \mathrm{XJ} 227 \mathrm{~A}$ & 117 o & 8 & 205.8 & -25.2 & 3.5 & 320 & 670 & -57.1 & 50.7 & 169.7 \\
\hline $15 \mathrm{XCJ} 228 \mathrm{~A}$ & 117.5 o & 9 & 198.2 & -22.7 & 5.3 & 320 & 670 & -60.3 & 63.9 & 165.7 \\
\hline $15 X C J 229 A$ & 118 o & 8 & 204.8 & -32.2 & 2.2 & 320 & 670 & -61 & 46.5 & 176.7 \\
\hline $15 \times C J 230 \mathrm{~A}$ & 118.5 o & 8 & 207.3 & -42.8 & 4.8 & 320 & 670 & -63.9 & 31 & 172.6 \\
\hline $15 \times C J 231 \mathrm{~A}$ & 119 o & 9 & 218.4 & -46 & 5.5 & 320 & 670 & -56.4 & 16.7 & 165.6 \\
\hline $15 X C J 232 \mathrm{~A}$ & 119.5 o & 8 & 182.8 & -37.9 & 4.3 & 320 & 670 & -74.4 & 92.1 & 161.8 \\
\hline $15 \mathrm{XCJ} 233 \mathrm{~A}$ & 120 o & 9 & 226.4 & -19.5 & 7.1 & 320 & 670 & -40.5 & 32.4 & 155.5 \\
\hline $15 \times C J 234 \mathrm{~A}$ & $120.5 \circ$ & 8 & 200.6 & -26.5 & 9.4 & 320 & 670 & -60.9 & 57.5 & 170.1 \\
\hline $15 \times C J 235 \mathrm{~A}$ & 1210 & 3 & 214.2 & -34.4 & 6.1 & 570 & 670 & -55.2 & 33.2 & 172.7 \\
\hline $15 X \mathrm{XJ} 236 \mathrm{~A}$ & $121.5 \circ$ & 8 & 227 & -13.3 & 4.6 & 320 & 670 & -37.8 & 35.1 & 150.4 \\
\hline $15 X C J 242 A$ & $124.5 \circ$ & 7 & 14.1 & 42.8 & 2.1 & 320 & 620 & 73.2 & 232.3 & 11.4 \\
\hline $15 X \mathrm{XJ} 243 \mathrm{~A}$ & $125 \circ$ & 8 & 44.9 & 58 & 1.8 & 320 & 630 & 54.8 & 174.7 & 25.9 \\
\hline $15 \times C J 244 A$ & 125.5 o & 7 & 74.7 & 71.4 & 5.7 & 320 & 620 & 37.8 & 145.1 & 43.9 \\
\hline $15 \times C J 245 A$ & 125.9 o & 7 & -8.6 & 21 & 5 & 320 & 620 & 63.1 & 300.8 & 33 \\
\hline $15 \times C J 246 \mathrm{~A}$ & $126.5 \circ$ & 8 & -10.6 & 33.5 & 2 & 320 & 630 & 69.5 & 311.8 & 29.5 \\
\hline $15 \times C J 247 \mathrm{~A}$ & 127 o & 8 & 20.3 & 23.3 & 1 & 320 & 670 & 59.5 & 240.1 & 13 \\
\hline $15 \times C J 248 A$ & 127.6 o & 8 & 16 & 17.3 & 1.7 & 320 & 630 & 58.6 & 250.3 & 20 \\
\hline $15 X C J 249 A$ & 128 o & 7 & 20 & 39.8 & 2.8 & 320 & 620 & 67.8 & 225.3 & 6.1 \\
\hline $15 \times C J 250 \mathrm{~A}$ & $128.5 \circ$ & 7 & 36.3 & 36.8 & 2.1 & 320 & 620 & 54.6 & 208.9 & 8.9 \\
\hline $15 X C J 251 \mathrm{~A}$ & 129 o & 7 & 24.5 & 38.6 & 2.2 & 320 & 620 & 64.1 & 220.2 & 3.2 \\
\hline $15 X C J 252 A$ & 129.5 o & 7 & 25.8 & 41.4 & 2.4 & 320 & 630 & 64.4 & 214.9 & 5.9 \\
\hline $15 X C J 253 \mathrm{~A}$ & $130 \circ$ & 7 & 16.9 & 40.5 & 1.3 & 320 & 620 & 70.2 & 230.2 & 8.4 \\
\hline $15 X C J 254 \mathrm{~A}$ & 130.5 o & 7 & 43.6 & 65.2 & 3.1 & 320 & 620 & 56.4 & 159.7 & 31.6 \\
\hline $15 \times C J 255 \mathrm{~A}$ & 131 o & 8 & 24.7 & 35.2 & 1.9 & 320 & 630 & 62.4 & 223.7 & 0.6 \\
\hline $15 \times C J 256 \mathrm{~A}$ & $131.5 \circ$ & 7 & 25.9 & 28.3 & 4 & 320 & 620 & 58.5 & 228.3 & 7.2 \\
\hline $15 \times C J 257 \mathrm{~A}$ & $132 \circ$ & 7 & 9.5 & 38.8 & 2.9 & 320 & 620 & 73.1 & 250.2 & 13.1 \\
\hline $15 X \mathrm{XJ} 258 \mathrm{~A}$ & 132.4 o & 8 & 18.8 & 27.1 & 3.8 & 320 & 630 & 62.1 & 240.1 & 10.1 \\
\hline $15 X C J 259 A$ & 133 o & 7 & 34.3 & 69 & 5.3 & 320 & 620 & 61.3 & 147.4 & 33.9 \\
\hline $15 \times C J 260 \mathrm{~A}$ & $133.5 \circ$ & 6 & 45.4 & 46.7 & 12.3 & 320 & 620 & 51 & 191.5 & 18.7 \\
\hline $15 \times C J 261 \mathrm{~A}$ & $134 \circ$ & 8 & 32.2 & 39.4 & 2.7 & 320 & 630 & 58.8 & 210.2 & 6.6 \\
\hline $15 X C J 262 A$ & 134.5 o & 7 & 14 & 37.1 & 2.9 & 320 & 620 & 70 & 240.6 & 9.3 \\
\hline $15 X C J 263 \mathrm{~A}$ & $135 \circ$ & 8 & 38.5 & 58.2 & 2.3 & 320 & 670 & 59.7 & 175.8 & 24.3 \\
\hline $15 \times C J 264 A$ & 135.5 o & 8 & 49.5 & 46.6 & 3.3 & 320 & 630 & 47.7 & 189.2 & 21.1 \\
\hline $15 X C J 265 A$ & 136 o & 7 & -4.3 & 53.7 & 2.2 & 320 & 620 & 85.8 & 338.7 & 27.5 \\
\hline $15 X C J 269 \mathrm{~A}$ & $138.5 \circ$ & 8 & 22.3 & 34.7 & 2.7 & 320 & 670 & 63.8 & 227.9 & 2.7 \\
\hline $15 \times C J 270 \mathrm{~A}$ & 139.5 o & 9 & 39.6 & 17.5 & 3 & 320 & 670 & 44.7 & 219.6 & 22 \\
\hline $15 \times C J 271 \mathrm{~A}$ & 140.5 o & 7 & 28.9 & 62.7 & 5.8 & 320 & 620 & 66.9 & 164 & 27.3 \\
\hline $15 X C J 272 A$ & 141.5 o & 8 & 2.9 & 24.7 & 2.2 & 320 & 670 & 66.2 & 275 & 22.2 \\
\hline $15 X C J 273 A$ & $142.5 \circ$ & 9 & 46 & 29.6 & 2.7 & 320 & 670 & 44.4 & 206.5 & 18.3 \\
\hline $15 \times C J 274 A$ & 143.5 o & 7 & 50.8 & 62.9 & 2.9 & 320 & 620 & 51.3 & 164.3 & 31.5 \\
\hline $15 \times C J 275 A$ & $144.5 \circ$ & 7 & 30.6 & 14.3 & 1.9 & 320 & 620 & 49.6 & 230.9 & 21.7 \\
\hline $15 \times C J 276 \mathrm{~A}$ & 145.5 o & 8 & 5.9 & 43.2 & 1.7 & 320 & 630 & 77.5 & 256.5 & 16.9 \\
\hline $15 \mathrm{XCJ} 278 \mathrm{~A}$ & $147.5 \circ$ & 8 & 11.1 & 28.2 & 1.5 & 320 & 670 & 66.2 & 254.6 & 14.2 \\
\hline $15 \times C J 279 A$ & $148.5 \circ$ & 9 & 32.8 & 26.6 & 0.9 & 320 & 670 & 53.1 & 221 & 10.9 \\
\hline $15 \mathrm{XCJ} 280 \mathrm{~A}$ & $149.5 \circ$ & 8 & 23 & 42.1 & 1.2 & 320 & 670 & 66.7 & 217.4 & 6.9 \\
\hline $15 \times C J 281 \mathrm{~A}$ & 150.5 o & 8 & -0.4 & 30.7 & 6.6 & 320 & 670 & 69.9 & 283.1 & 22.1 \\
\hline $15 X C J 282 \mathrm{~A}$ & 151.5 o & 8 & 14.1 & 3.4 & 1.2 & 320 & 630 & 52.7 & 258.3 & 33.7 \\
\hline $15 X \mathrm{XJ} 283 \mathrm{~A}$ & 152.5 o & 7 & 49.6 & 29.8 & 4.7 & 320 & 670 & 41.7 & 203.6 & 21.1 \\
\hline
\end{tabular}




\begin{tabular}{|c|c|c|c|c|c|c|c|c|c|c|}
\hline $15 X \mathrm{XJ} 284 \mathrm{~A}$ & 153.5 o & 8 & 40.2 & 22.7 & 1.8 & 320 & 670 & 46.2 & 216 & 18.2 \\
\hline $15 X C J 285 \mathrm{~A}$ & 154.5 o & 8 & 31.5 & 39.4 & 5.4 & 320 & 630 & 59.3 & 210.8 & 6.2 \\
\hline $15 X \mathrm{XJ} 286 \mathrm{~A}$ & 155.5 o & 8 & 18.3 & 33.2 & 1.7 & 320 & 670 & 65.5 & 236.1 & 6.3 \\
\hline $15 X C J 287 \mathrm{~A}$ & 156.5 o & 7 & 29.8 & 30.9 & 3.3 & 320 & 620 & 56.9 & 221.2 & 5.9 \\
\hline $15 X C J 288 A$ & 157.5 o & 8 & 21.8 & 45.6 & 3 & 320 & 630 & 69.2 & 213.3 & 10.4 \\
\hline $15 X \mathrm{XJ} 289 \mathrm{~A}$ & 158.5 o & 8 & 19.1 & 35.7 & 2.9 & 320 & 670 & 66.3 & 232.2 & 5.2 \\
\hline $15 X \mathrm{CJ} 290 \mathrm{~A}$ & 159.5 o & 7 & 41.9 & 43.5 & 1.6 & 320 & 620 & 52.7 & 197.4 & 15 \\
\hline $15 X C J 291 \mathrm{~A}$ & $160.5 \circ$ & 8 & 13.6 & 47.7 & 1.7 & 320 & 630 & 76.2 & 222.5 & 15 \\
\hline $15 X C J 292 A$ & 161.5 o & 8 & 0.6 & 35 & 1.3 & 320 & 670 & 72.7 & 280 & 20.2 \\
\hline $15 X C J 293 A$ & $162.5 \circ$ & 7 & 11.5 & 40 & 1.1 & 320 & 620 & 73 & 243.3 & 11.9 \\
\hline $15 X C J 294 A$ & $163.5 \circ$ & 9 & 23.6 & 47.9 & 4.2 & 320 & 670 & 68.8 & 206.5 & 12.4 \\
\hline $15 X C J 295 A$ & 164.5 o & 8 & 60 & 46.2 & 3.8 & 320 & 670 & 39.2 & 184 & 28 \\
\hline $15 X \mathrm{XJ} 296 \mathrm{~A}$ & 165.5 o & 8 & 21.8 & 55.6 & 2.2 & 320 & 670 & 72.5 & 187 & 20.2 \\
\hline $15 X \mathrm{CJ} 297 \mathrm{~A}$ & $166.5 \circ$ & 9 & 29.2 & 18.6 & 1.9 & 320 & 670 & 52.2 & 230.3 & 17.2 \\
\hline $15 X C J 298 A$ & 167.5 o & 8 & 55.9 & 29.1 & 1.3 & 320 & 670 & 36.4 & 199.6 & 26.4 \\
\hline $15 X C J 299 A$ & $168.5 \circ$ & 7 & 20.9 & 45.8 & 1.6 & 320 & 620 & 70 & 214 & 10.9 \\
\hline $15 \times C J 300 A$ & 169.5 o & 9 & 223.9 & -54.2 & 5.4 & 320 & 520 & -54.6 & 1.6 & 157.3 \\
\hline $15 \times C J 302 \mathrm{~A}$ & $171.3 \circ$ & 7 & 229 & -63.8 & 10.1 & 320 & 620 & -52.6 & 342.6 & 148.3 \\
\hline $15 \mathrm{XCJ} 303 \mathrm{~A}$ & $172.5 \circ$ & 8 & 171.3 & -52.6 & 1.6 & 320 & 630 & -82.1 & 168.9 & 150.5 \\
\hline $15 \times C J 304 A$ & 173.5 o & 8 & 228.9 & -16.2 & 1.8 & 320 & 670 & -37.4 & 32.1 & 151.5 \\
\hline $15 \times C J 306 \mathrm{~A}$ & 175.5 o & 8 & 213.7 & -23.5 & 11.8 & 320 & 630 & -51.2 & 42 & 166 \\
\hline $15 \times C J 307 \mathrm{~A}$ & 176.5 o & 7 & 171 & -49.4 & 7.2 & 320 & 620 & -80.1 & 154.2 & 151.4 \\
\hline $15 \times C J 309 A$ & 178.5 o & 10 & 197.5 & -26.3 & 0.6 & 320 & 670 & -62.4 & 63 & 168.5 \\
\hline $15 \times C J 311 \mathrm{~A}$ & 180.5 o & 8 & 199.5 & -38.9 & 7.8 & 320 & 670 & -67.7 & 47.5 & 174.2 \\
\hline $15 \times C J 312 \mathrm{~A}$ & 181.5 o & 9 & 181.5 & -20.6 & 1 & 320 & 670 & -64 & 98.7 & 154.3 \\
\hline $15 \times C J 314 \mathrm{~A}$ & 183.7 o & 8 & 196.6 & -40.8 & 2.9 & 320 & 670 & -70.5 & 50.2 & 171.3 \\
\hline $15 \times C J 315 A$ & 184.5 o & 8 & 209 & -22.3 & 3.3 & 320 & 630 & -53.9 & 48.3 & 166.4 \\
\hline $15 \times C J 316 \mathrm{~A}$ & 185.5 o & 8 & 187.9 & -36.3 & 4.4 & 320 & 670 & -72.2 & 77 & 165.8 \\
\hline $15 \times C J 319 A$ & 188.5 o & 8 & 27.5 & 38.1 & 1.7 & 320 & 670 & 61.7 & 216.9 & 3.1 \\
\hline $15 \times C J 320 \mathrm{~A}$ & 189.5 o & 8 & 11.8 & 56.9 & 1.9 & 320 & 670 & 80.6 & 183.3 & 23.3 \\
\hline $15 \times C J 321 \mathrm{~A}$ & 190.5 o & 8 & 48.9 & 45.8 & 2.6 & 320 & 630 & 47.9 & 190.4 & 20.5 \\
\hline $15 \times C J 323 \mathrm{~A}$ & $192.5 \circ$ & 8 & 194.3 & -15.6 & 8.7 & 320 & 630 & -58.5 & 74 & 157.8 \\
\hline $15 \times C J 326 \mathrm{~A}$ & 195.5 o & 7 & 234.4 & -30 & 2.7 & 320 & 620 & -37.9 & 20.1 & 155.1 \\
\hline $15 \times C J 327 A$ & 196.5 o & 8 & 223.1 & -34.3 & 5.3 & 320 & 630 & -48.4 & 25.3 & 165.5 \\
\hline $15 X \mathrm{CJ} 328 \mathrm{~A}$ & 197.5 o & 8 & 209.1 & -50.9 & 2.9 & 320 & 670 & -65.5 & 15.1 & 164.3 \\
\hline $15 \times C J 329 A$ & 198.5 o & 8 & 245.2 & -48.9 & 5.5 & 320 & 670 & -36.1 & 359 & 148.1 \\
\hline $15 \times C J 331 \mathrm{~A}$ & 200.50 & 8 & 199 & -0.3 & 6 & 320 & 670 & -49.5 & 71.9 & 144.3 \\
\hline $15 \times C J 332 \mathrm{~A}$ & 201.5 o & 7 & 229.2 & -71 & 4.5 & 320 & 620 & -52.1 & 326.3 & 142.3 \\
\hline $15 \times C J 333 \mathrm{~A}$ & 202.50 & 8 & 210.2 & -52.8 & 3.3 & 320 & 670 & -65.2 & 10.4 & 162.3 \\
\hline $15 \times C J 334 \mathrm{~A}$ & $203.5 \circ$ & 8 & 212.8 & -40.7 & 6.1 & 320 & 670 & -58.8 & 28 & 172.2 \\
\hline $15 \times C J 335 A$ & 204.7 o & 7 & 187.8 & -52.7 & 2.6 & 320 & 620 & -82.8 & 37.6 & 158.8 \\
\hline $15 \times C J 336 \mathrm{~A}$ & $205.5 \circ$ & 8 & 204.3 & -36.6 & 1.5 & 320 & 630 & -63.3 & 42.8 & 178.6 \\
\hline $15 \times C J 337 \mathrm{~A}$ & $206.4 \circ$ & 7 & 208.5 & -51.8 & 1.1 & 320 & 620 & -66.3 & 13.8 & 163.6 \\
\hline $16 \times C J 006 \mathrm{~A}$ & 2210 & 7 & 190.7 & -25.2 & 2.2 & 320 & 620 & -64.7 & 76.9 & 163.7 \\
\hline $16 \times C J 006 B$ & 2210 & 6 & 198.6 & -37.1 & 1.5 & 370 & 620 & -67.3 & 51.3 & 174.3 \\
\hline $16 \times C J 008 \mathrm{~A}$ & 2240 & 7 & 179 & -3.8 & 2 & 320 & 620 & -55.3 & 103.7 & 140 \\
\hline $16 \times C J 009 A$ & 224.50 & 7 & 185 & -3.9 & 2.1 & 320 & 620 & -55 & 93.2 & 143.3 \\
\hline $16 \times C J 010 \mathrm{~A}$ & 227.50 & 7 & 217.1 & -35.1 & 2.4 & 320 & 620 & -53.3 & 29.7 & 170.4 \\
\hline $16 \times C J 011 \mathrm{~A}$ & 2280 & 8 & 219.5 & -8.1 & 2.7 & 320 & 620 & -41.3 & 44.3 & 149.7 \\
\hline $16 \times C J 012 \mathrm{~A}$ & $228.7 \circ$ & 7 & 210 & -22.3 & 1.6 & 320 & 620 & -53.2 & 47.1 & 166.2 \\
\hline $16 \times C J 013 \mathrm{~A}$ & 230.10 & 7 & 204.3 & -39.5 & 1.3 & 320 & 620 & -64.7 & 39.3 & 175.9 \\
\hline $16 \mathrm{XCJ} 014 \mathrm{~A}$ & 2310 & 6 & 178.1 & -46.2 & 2.6 & 370 & 620 & -80.8 & 112.6 & 156.9 \\
\hline 16 XCJ015A & 232.10 & 7 & 240.5 & -12.6 & 1.3 & 320 & 620 & -27.3 & 25.2 & 140.9 \\
\hline $16 \times C J 016 \mathrm{~A}$ & 233.10 & 7 & 236.5 & -27.5 & 3.9 & 320 & 620 & -35.3 & 20.2 & 152.4 \\
\hline $16 \times \mathrm{XJ016B}$ & 233.10 & 6 & 222.5 & -14.2 & 1.2 & 370 & 620 & -41.5 & 38.6 & 153.7 \\
\hline 16XCJ017A & 2340 & 7 & 218.1 & -47.9 & 1.6 & 320 & 620 & -57.3 & 14.2 & 164.4 \\
\hline $16 \times C J 018 \mathrm{~A}$ & $235 \circ$ & 7 & 220.7 & -35.2 & 2.1 & 320 & 620 & -50.6 & 26.5 & 167.5 \\
\hline 16XCJ019A & 236.10 & 7 & 166.5 & -24.3 & 3.9 & 320 & 620 & -63.2 & 132.3 & 144.7 \\
\hline $16 \times C J 020 \mathrm{~A}$ & $237.3 \circ$ & 6 & 186.9 & -43.9 & 2.4 & 320 & 570 & -77.6 & 71.7 & 163.5 \\
\hline $16 \times C J 021 \mathrm{~A}$ & $238.5 \circ$ & 7 & 201.6 & -35.7 & 1.7 & 320 & 620 & -64.7 & 47.9 & 176.9 \\
\hline $16 \times C J 022 \mathrm{~A}$ & 239.4 o & 7 & 200.7 & -15.2 & 0.7 & 320 & 620 & -55.5 & 63.8 & 159.2 \\
\hline $16 \mathrm{XCJ} 023 \mathrm{~A}$ & $239.9 \circ$ & 7 & 177.5 & -58.7 & 2.4 & 320 & 620 & -86.6 & 247.8 & 150.5 \\
\hline $16 \times C J 023 B$ & $239.9 \circ$ & 7 & 205.7 & -37.4 & 3.3 & 320 & 620 & -62.7 & 40 & 178.1 \\
\hline $16 \mathrm{XCJ} 024 \mathrm{~A}$ & 241.10 & 6 & 228.7 & -49.1 & 0.9 & 370 & 620 & -49.2 & 6.7 & 158.2 \\
\hline $16 \mathrm{XCJ} 025 \mathrm{~A}$ & $241.7 \circ$ & 7 & 239.1 & -33.7 & 2 & 320 & 620 & -35.5 & 14.6 & 152.4 \\
\hline $16 \mathrm{XCJ} 026 \mathrm{~A}$ & 242.60 & 7 & 249.5 & -40.7 & 2 & 320 & 620 & -29.6 & 3.7 & 145.3 \\
\hline 16XCJ027A & 243.40 & 7 & 203.6 & -26.1 & 2 & 320 & 620 & -59 & 53.2 & 170.5 \\
\hline $16 \mathrm{XCJ} 028 \mathrm{~A}$ & $244.7 \circ$ & 7 & 217.5 & -50.4 & 2 & 320 & 620 & -58.6 & 10.8 & 162.7 \\
\hline 16XCJ029A & 245.50 & 7 & 190.2 & -24.8 & 2.1 & 320 & 620 & -64.7 & 78.3 & 163 \\
\hline 16XCJ031B & $247.5 \circ$ & 7 & 202.9 & -18.6 & 2.7 & 320 & 620 & -55.9 & 58.7 & 162.9 \\
\hline $16 \mathrm{XCJ} 032 \mathrm{~A}$ & 2490 & 7 & 218.4 & -32.3 & 3.6 & 320 & 620 & -51.2 & 31 & 168.8 \\
\hline $16 \mathrm{XCJ033A}$ & $250.5 \circ$ & 7 & 213.5 & -36.1 & 1.5 & 320 & 620 & -56.4 & 32.4 & 173.4 \\
\hline $16 \mathrm{XCJ} 034 \mathrm{~A}$ & 2540 & 7 & 195.4 & -33.8 & 5.8 & 320 & 620 & -67.4 & 61.1 & 171.6 \\
\hline $16 \times C J 036 \mathrm{~A}$ & $256 \circ$ & 7 & 210.9 & -41.8 & 3.8 & 320 & 620 & -60.7 & 28.6 & 172.4 \\
\hline 16XCJ037A & 257.5 o & 7 & 203.4 & -18.3 & 4.3 & 320 & 620 & -55.5 & 58.2 & 162.7 \\
\hline $16 \times C J 038 \mathrm{~A}$ & $258 \circ$ & 7 & 229.2 & -16.3 & 3.2 & 320 & 620 & -37.2 & 31.7 & 151.4 \\
\hline $16 \mathrm{XCJ} 040 \mathrm{~A}$ & $260 \circ$ & 7 & 28.2 & 31.7 & 2.7 & 320 & 620 & 58.4 & 222.4 & 4.5 \\
\hline $16 \times C J 041 \mathrm{~A}$ & 262.50 & 7 & 45.8 & 27.4 & 7.9 & 320 & 620 & 43.7 & 208.2 & 19.2 \\
\hline $16 \mathrm{XCJ} 042 \mathrm{~A}$ & 2640 & 7 & 8 & -6.1 & 2.8 & 320 & 620 & 49.6 & 269.7 & 44.7 \\
\hline $16 \mathrm{XCJ} 043 \mathrm{~A}$ & $266.25 \circ$ & 7 & 39.1 & 1.9 & 1.1 & 320 & 620 & 39.2 & 227.5 & 36 \\
\hline
\end{tabular}




\begin{tabular}{|c|c|c|c|c|c|c|c|c|c|c|}
\hline $16 \times C J 044 \mathrm{~A}$ & 269.20 & 7 & 38.6 & 6.5 & 3.8 & 320 & 620 & 41.3 & 226 & 31.4 \\
\hline $16 \times C J 045 A$ & 270.1 o & 7 & 30 & 67.6 & 1.5 & 320 & 620 & 64.5 & 149.4 & 32.2 \\
\hline $16 \times C J 046 \mathrm{~A}$ & $273.3 \circ$ & 7 & -6.8 & 20.4 & 5.4 & 320 & 620 & 63.2 & 296.9 & 32 \\
\hline \multicolumn{11}{|l|}{45 cutoff } \\
\hline $15 X C J 089 A$ & 49.50 & 7 & 215.6 & 8.7 & 1.4 & 320 & 620 & -37.3 & 55.2 & 134.8 \\
\hline $15 X C J 136 \mathrm{~A}$ & $72.5 \circ$ & 8 & 74.7 & 16.8 & 1.5 & 320 & 630 & 17.3 & 194.1 & 47.5 \\
\hline $15 X C J 140 A$ & 74.5 o & 8 & 82.1 & 24.8 & 2.6 & 320 & 670 & 14 & 186 & 49.5 \\
\hline $15 X \mathrm{CJ} 141 \mathrm{~A}$ & 750 & 7 & 79.4 & 26.4 & 4.5 & 320 & 620 & 16.7 & 186.8 & 46.6 \\
\hline $15 X C J 161 \mathrm{~A}$ & 84.50 & 8 & 140.4 & 62.1 & 3.8 & 320 & 670 & -2.3 & 129.7 & 69.4 \\
\hline $15 X C J 212 A$ & 110 o & 8 & 263.3 & -23.5 & 1.7 & 320 & 670 & -12.6 & 5.9 & 128.9 \\
\hline $15 \mathrm{XCJ} 240 \mathrm{~A}$ & $123.5 \circ$ & 9 & -17.2 & 1.5 & 4.9 & 320 & 670 & 50.8 & 309.8 & 52.1 \\
\hline $15 \times C J 241 \mathrm{~A}$ & $124 \circ$ & 8 & -23.3 & -11.9 & 7.1 & 320 & 670 & 42.1 & 314.1 & 66 \\
\hline $15 \times C J 310 A$ & 179.5 o & 8 & -69.9 & -57.1 & 4.9 & 320 & 670 & -8.5 & 330.6 & 121.9 \\
\hline $15 \times C J 317 \mathrm{~A}$ & $186.5 \circ$ & 8 & -66 & -69.4 & 2.2 & 320 & 670 & -16.4 & 316.8 & 123.4 \\
\hline $15 \mathrm{XCJ} 330 \mathrm{~A}$ & 199.5 o & 8 & 136.3 & -55.3 & 5.2 & 320 & 630 & -55.1 & 204.2 & 130 \\
\hline
\end{tabular}




\begin{tabular}{|c|c|c|c|c|c|c|c|c|c|c|}
\hline Sample & Strat. Pos. ( fo & $r$ of & lination & hation & MAD & Min Temp i & emp & latitud & Longit। & le from th \\
\hline 16XXJ004A & $13.5 \circ$ & 7 & 227.1 & -60.9 & 3 & 320 & 650 & -53.6 & 348.4 & 151.6 \\
\hline 16XXJ005A & $15.3 \circ$ & 7 & 246.8 & -18 & 2.3 & 320 & 650 & -24.1 & 18.3 & 142 \\
\hline 16XXJ007A & $17 \circ$ & 7 & 245.6 & -33.8 & 3.2 & 320 & 650 & -30.2 & 10.4 & 149.6 \\
\hline 16XXJ008A & 20.40 & 7 & 236.1 & -34.1 & 4.3 & 320 & 650 & -37.9 & 16 & 157.3 \\
\hline 16XXJ009A & 21.60 & 7 & 229.1 & -34.9 & 2.5 & 320 & 650 & -43.9 & 20.1 & 163.2 \\
\hline 16XXJ009B & $21.6 \circ$ & 5 & 16.1 & 22.1 & 6.6 & 320 & 520 & 61.1 & 247.7 & 17 \\
\hline 16XXJ010A & 22.40 & 6 & 34.9 & 14.8 & 6 & 320 & 650 & 47 & 225.6 & 21.1 \\
\hline 16XXJ011A & 23.90 & 8 & 31.3 & 34.8 & 3.5 & 320 & 650 & 57.5 & 215.7 & 2.3 \\
\hline 16XXJ012A & $24.9 \circ$ & 7 & 45.6 & 4.1 & 4.5 & 320 & 650 & 35.6 & 220.3 & 34.9 \\
\hline 16XXJ013A & $26.9 \circ$ & 7 & 26.3 & 42.8 & 3 & 320 & 650 & 64.7 & 211.9 & 7.8 \\
\hline 16XXJ014A & $28.1 \circ$ & 7 & 23.9 & 43.7 & 5.1 & 320 & 650 & 66.9 & 213.4 & 9.2 \\
\hline 16XXJ015A & 29.10 & 7 & 35 & 6.9 & 7.2 & 320 & 650 & 43.9 & 229.2 & 28.9 \\
\hline 16XXJ016A & $30 \circ$ & 7 & 35 & 33.8 & 5.4 & 320 & 650 & 54.4 & 212.7 & 5.5 \\
\hline 16XXJ017A & 31.1 o & 7 & 39.1 & 60.4 & 4.2 & 320 & 650 & 59.5 & 170.6 & 26.1 \\
\hline 16XXJ018A & 32.40 & 7 & 60.4 & 34.5 & 4.9 & 320 & 650 & 34.7 & 193 & 26.1 \\
\hline 16XXJ019A & $33.5 \circ$ & 3 & 221.8 & -14.6 & 7.2 & 520 & 650 & -42.1 & 38.8 & 156.1 \\
\hline 16XXJ021A & $38.9 \circ$ & 7 & 192 & -4.2 & 4.1 & 320 & 650 & -53.9 & 81.2 & 145.5 \\
\hline 16XXJ024A & 420 & 7 & 225.1 & -18.1 & 4.8 & 320 & 650 & -41 & 34.1 & 157.4 \\
\hline 16XXJ025B & 430 & 7 & 248.1 & -18.8 & 2.1 & 320 & 650 & -23.3 & 17.2 & 141.4 \\
\hline 16XXJ026A & 440 & 7 & 39.7 & 43.1 & 4.2 & 320 & 650 & 54.4 & 199.2 & 11.7 \\
\hline 16XXJ027A & $44.9 \circ$ & 7 & 64.4 & 42 & 5.5 & 320 & 650 & 34.1 & 185.2 & 28.7 \\
\hline 16XXJ028A & $45.8 \circ$ & 7 & 47 & 33.6 & 2 & 320 & 650 & 45 & 202.6 & 15.3 \\
\hline 16XXJ029A & 46.50 & 5 & 41.8 & 51 & 2.5 & 320 & 520 & 55.3 & 187.3 & 18.5 \\
\hline 16XXJ030A & 470 & 5 & 26.5 & 28.3 & 3.5 & 320 & 520 & 58.1 & 227.2 & 7.1 \\
\hline 16XXJ031A & 48.10 & 4 & 86.5 & 52.3 & 2.5 & 370 & 520 & 21.4 & 166.1 & 43.8 \\
\hline 16XXJ032A & 49.20 & 5 & 53.8 & 11.4 & 2.5 & 320 & 520 & 32.1 & 210.4 & 33.1 \\
\hline 16XXJ033A & $50 \circ$ & 5 & 21 & 36.3 & 2.4 & 320 & 520 & 65.4 & 227.8 & 6.1 \\
\hline 16XXJ034A & 51.25 o & 5 & 56.1 & 15.2 & 2.1 & 320 & 520 & 31.7 & 206.9 & 31.7 \\
\hline 16XXJ036A & 52.9 o & 5 & 59.5 & 44.4 & 1.8 & 320 & 520 & 38.9 & 185.8 & 25.4 \\
\hline 16XXJ037A & 54.20 & 5 & 48.5 & 33.7 & 1.7 & 320 & 520 & 43.9 & 201.5 & 16.5 \\
\hline 16XXJ038A & 54.9 o & 5 & 58.1 & 40.1 & 2.3 & 300 & 450 & 38.5 & 190.3 & 23.8 \\
\hline 16XXJ039A & 560 & 5 & 37.9 & 35.5 & 5.2 & 320 & 520 & 52.9 & 208.5 & 7.6 \\
\hline 16XXJ040A & 570 & 5 & 31.2 & 20.2 & 2.2 & 320 & 520 & 51.6 & 226.8 & 15.2 \\
\hline 16XXJ041A & $58.5 \circ$ & 5 & 34.9 & 40.2 & 3.6 & 320 & 520 & 57 & 206.4 & 7.1 \\
\hline $16 \mathrm{XXJ042A}$ & 59.10 & 4 & 51.6 & 40.1 & 2.9 & 320 & 470 & 43.7 & 194.2 & 18.9 \\
\hline 16XXJ043A & 59.8 o & 4 & 44.2 & 37.6 & 3.5 & 320 & 470 & 48.8 & 201.4 & 12.8 \\
\hline 16XXJ044A & 60.6 o & 5 & 61.1 & 41.1 & 3.7 & 320 & 520 & 36.4 & 187.8 & 26.2 \\
\hline 16XXJ045A & 610 & 5 & 38.3 & 59.4 & 3.6 & 320 & 520 & 59.9 & 173 & 25 \\
\hline 16XXJ046A & 61.9 o & 5 & 3.8 & 29.8 & 2.8 & 320 & 520 & 69.2 & 271.5 & 21.4 \\
\hline 16XXJ047A & 63.40 & 5 & 227.9 & -21.6 & 3.8 & 320 & 520 & -40.1 & 29.8 & 158.2 \\
\hline 16XXJ048A & 63.70 & 5 & 163.1 & -31.2 & 3.3 & 320 & 520 & -65.3 & 143.5 & 142.2 \\
\hline 16XXJ049A & $64.2 \circ$ & 5 & 265.8 & -41.9 & 2.2 & 320 & 520 & -17.3 & 354.2 & 135.6 \\
\hline 16XXJ050A & $65.4 \circ$ & 5 & 239.9 & -7.9 & 2.8 & 320 & 520 & -26.3 & 27.5 & 140.4 \\
\hline 16XXJ051A & 660 & 5 & 246.1 & -33.2 & 3.5 & 320 & 520 & -29.6 & 10.5 & 149 \\
\hline 16XXJ052A & 670 & 5 & 248.2 & -28 & 2.3 & 320 & 520 & -26.2 & 12.3 & 145.6 \\
\hline 16XXJ053A & 67.50 & 5 & 181.2 & -71.6 & 2.3 & 320 & 520 & -70.1 & 283.8 & 140.9 \\
\hline 16XXJ055A & 69 o & 5 & 232.1 & -13.1 & 3.3 & 320 & 520 & -34 & 30.9 & 149.3 \\
\hline 16XXJ056A & 700 & 5 & 232.9 & -8.3 & 4.2 & 320 & 520 & -31.8 & 32.5 & 145.1 \\
\hline 16XXJ057A & 71 o & 3 & 227.5 & -43.5 & 3.6 & 420 & 520 & -48.3 & 13.5 & 163.2 \\
\hline 16XXJ058A & 71.8 o & 5 & 241.1 & -24.4 & 2.6 & 320 & 520 & -30.7 & 18.8 & 149.9 \\
\hline 16XXJ059A & $73.2 \circ$ & 5 & 234.4 & -16.7 & 6.7 & 320 & 520 & -33.4 & 27.4 & 150.4 \\
\hline 16XXJ060A & 74.2 o & 5 & 233.2 & -45.6 & 2.5 & 320 & 520 & -44.4 & 8 & 158.6 \\
\hline 16XXJ061A & 75.2 o & 5 & 262.7 & -33.8 & 2.6 & 320 & 520 & -16.6 & 0.8 & 135.9 \\
\hline 16XXJ062A & 760 & 5 & 244.5 & -37.4 & 4 & 320 & 520 & -32.4 & 8.6 & 151.1 \\
\hline $17 X X J 01 A$ & $78.5 \circ$ & 9 & 231.9 & 1.9 & 7.2 & 300 & 640 & -29.1 & 37.7 & 136.9 \\
\hline $17 X X J 02 A$ & 79 o & 9 & 233.4 & 2.3 & 4.4 & 300 & 640 & -27.8 & 36.6 & 135.9 \\
\hline 17XXJ03A & 800 & 9 & 218.1 & -20 & 1.5 & 300 & 640 & -46.8 & 39.5 & 162.6 \\
\hline 17XXJ06A & $82.5 \circ$ & 9 & 241.9 & -11.1 & 10.1 & 300 & 640 & -25.8 & 24.7 & 141.3 \\
\hline 17XXJ07A & $83.5 \circ$ & 9 & 251.5 & -17.7 & 8.1 & 300 & 640 & -20.2 & 15.5 & 138.1 \\
\hline 17XXJ08A & $84.5 \circ$ & 4 & 224.3 & -26.2 & 6.7 & 520 & 640 & -44.5 & 29.9 & 163.7 \\
\hline 17XXJ09A & $85.5 \circ$ & 9 & 264.1 & -37.1 & 8.7 & 300 & 640 & -16.7 & 358.1 & 135.7 \\
\hline $17 X X J 10 A$ & $86.5 \circ$ & 10 & 241.3 & -31.6 & 7.9 & 300 & 640 & -32.9 & 14.4 & 152.5 \\
\hline $17 X X J 11 A$ & 87.10 & 9 & 243 & -54.3 & 4.4 & 300 & 640 & -39.7 & 353.9 & 149.4 \\
\hline $17 X X J 12 A$ & 880 & 9 & 246.5 & -19 & 3.6 & 300 & 640 & -24.7 & 18 & 142.8 \\
\hline $17 X X J 14 A$ & 89.75 o & 9 & 227.9 & -25 & 3 & 300 & 640 & -41.3 & 27.8 & 160.5 \\
\hline $17 X X J 15 A$ & $90.5 \circ$ & 9 & 221.3 & -52.2 & 5.7 & 300 & 640 & -56.1 & 5.7 & 160.7 \\
\hline $17 X X J 16 A$ & 91 o & 9 & 240.1 & -26.3 & 2.4 & 300 & 640 & -32.1 & 18.3 & 151.5 \\
\hline 17XXJ17A & $91.75 \circ$ & 9 & 261.8 & -54 & 6.5 & 300 & 640 & -25.6 & 346.5 & 138.9 \\
\hline $17 X X J 18 A$ & $92.5 \circ$ & 9 & 225 & -17.6 & 4.7 & 300 & 640 & -40.9 & 34.4 & 157.1 \\
\hline $17 X X J 22 A$ & 960 & 9 & 242.2 & -27.2 & 7.7 & 300 & 640 & -30.7 & 16.4 & 150.2 \\
\hline $17 X X J 23 A$ & 97 o & 9 & 232.9 & -63.8 & 5.2 & 300 & 640 & -49.8 & 342 & 147.8 \\
\hline $17 X X J 24 A$ & 97.5 o & 9 & 246.4 & -11.5 & 3.2 & 300 & 640 & -22.3 & 21.6 & 138.3 \\
\hline $17 X X J 26 A$ & 99.5 o & 9 & 43.1 & 30.8 & 5 & 300 & 640 & 47.1 & 207.8 & 13 \\
\hline $17 X X J 27 A$ & 100.25 o & 9 & 66.7 & 21.7 & 5.8 & 300 & 640 & 25.3 & 196.6 & 35.9 \\
\hline $17 X X J 28 \mathrm{~A}$ & 101 o & 8 & 57.3 & 26.8 & 6.6 & 300 & 640 & 34.5 & 199.9 & 26 \\
\hline HGX128 & 108.7 o & 4 & 53.3 & 14.1 & 1.8 & 300 & 450 & 33.4 & 209.5 & 30.7 \\
\hline HGX125 & 111.3 o & 4 & 47.5 & 27.2 & 0.8 & 300 & 450 & 42.4 & 206.8 & 18.1 \\
\hline HGX124 & 112.20 & 4 & 55 & 24.4 & 3 & 300 & 450 & 35.6 & 202.9 & 25.2 \\
\hline HGX122 & 113.9 o & 4 & 20 & 5.5 & 2.3 & 300 & 450 & 51.5 & 248.5 & 30.7 \\
\hline
\end{tabular}




\begin{tabular}{|c|c|c|c|c|c|c|c|c|c|c|}
\hline HGX121 & 114.3 o & 4 & 41.8 & 39.4 & 1.6 & 300 & 450 & 51.3 & 201.5 & 11.4 \\
\hline HGX120 & 114.9 o & 4 & 55.1 & 42.9 & 1.7 & 300 & 450 & 41.9 & 189.6 & 21.9 \\
\hline HGX118 & 116.2 o & 4 & 50.4 & 11.3 & 2.9 & 300 & 450 & 34.7 & 213.1 & 31.1 \\
\hline HGX116 & 119.2 o & 4 & 48.1 & 38 & 1 & 300 & 450 & 45.8 & 198.3 & 15.9 \\
\hline HGX114 & 120.4 o & 4 & 45.2 & 30 & 4.1 & 300 & 450 & 45.1 & 206.6 & 15 \\
\hline HGX112 & $121.7 \mathrm{o}$ & 4 & 58.4 & 0.4 & 2.5 & 300 & 450 & 25 & 211.8 & 44.5 \\
\hline HGX110 & 122.9 o & 4 & 75 & 52.2 & 3.1 & 300 & 450 & 29.8 & 171.3 & 36.8 \\
\hline HGX108 & 123.9 o & 4 & 32.9 & 43.3 & 1.7 & 300 & 450 & 59.7 & 204.4 & 8.8 \\
\hline HGX106 & 125.3 o & 4 & 59 & 43.1 & 2.8 & 300 & 450 & 38.8 & 187.2 & 24.8 \\
\hline HGX104 & 126.5 o & 4 & 36.1 & 47.5 & 1.7 & 300 & 450 & 58.8 & 196 & 13.5 \\
\hline HGX100 & 131.2 o & 4 & 46.5 & -1.7 & 3.9 & 300 & 450 & 33 & 222.1 & 40.6 \\
\hline HGX98 & 132.7 o & 4 & 2 & 27.3 & 3.2 & 300 & 450 & 67.9 & 276.6 & 23.9 \\
\hline HGX96 & $133.5 \circ$ & 4 & 25.9 & 47.6 & 1.9 & 300 & 450 & 66.9 & 204.1 & 12.6 \\
\hline HGX94 & 134.5 o & 4 & 12.5 & 43.6 & 2.5 & 300 & 450 & 74.6 & 234.3 & 14.9 \\
\hline HGX91 & 138.6 o & 4 & 52.4 & 0 & 2.1 & 300 & 450 & 29.4 & 216.5 & 41.6 \\
\hline HGX87 & 140.7 o & 4 & 50.1 & 21.7 & 2.1 & 300 & 450 & 38.5 & 208 & 23.2 \\
\hline HGX85 & 143.1 o & 4 & 243.4 & -6.6 & 1.8 & 300 & 450 & -23.2 & 25.7 & 137.1 \\
\hline HGX83 & 145.9 o & 4 & 232.8 & -40.3 & 4.2 & 300 & 450 & -42.8 & 13.3 & 160.2 \\
\hline HGX80 & 147.7 o & 4 & 246.7 & -30.5 & 3.8 & 300 & 450 & -28.2 & 11.8 & 147.7 \\
\hline HGX78 & 148.9 o & 4 & 215.8 & -2.3 & 5.8 & 300 & 450 & -41.6 & 50.5 & 146.4 \\
\hline HGX72 & 152.9 o & 4 & 265.4 & -38.7 & 3.9 & 300 & 450 & -16.3 & 356.5 & 135.1 \\
\hline HGX71 & 153.2 o & 4 & 241.8 & -37.3 & 3.3 & 300 & 450 & -34.5 & 10.3 & 153.2 \\
\hline HGX65 & 158 o & 4 & 238.7 & -18.4 & 4.4 & 300 & 450 & -30.6 & 23.5 & 148.4 \\
\hline HGX61 & 161.7 o & 4 & 256.7 & -56.8 & 4 & 300 & 450 & -30.5 & 345.8 & 141.3 \\
\hline HGX60 & 162.7 o & 4 & 222.2 & -26.7 & 7.2 & 300 & 450 & -46.2 & 31.4 & 165.5 \\
\hline HGX57 & 162.9 o & 4 & 236.6 & -15.8 & 5.7 & 300 & 450 & -31.4 & 26.2 & 148.3 \\
\hline HGX52 & 169.3 o & 4 & 227.4 & -27.8 & 2.8 & 300 & 450 & -42.7 & 26.4 & 162.3 \\
\hline HGX44 & 171.5 o & 4 & 238.4 & -52.6 & 3.6 & 300 & 450 & -42.7 & 357.8 & 152.6 \\
\hline HGX42 & 172.20 & 4 & 240.3 & -19.4 & 4 & 300 & 450 & -29.7 & 21.9 & 147.8 \\
\hline HGX40 & 172.9 o & 4 & 205.3 & -15.3 & 13.8 & 300 & 450 & -53.2 & 56.9 & 159.9 \\
\hline HGX36 & $175.3 \circ$ & 4 & 46.9 & 26.4 & 1.9 & 300 & 450 & 42.6 & 207.7 & 18 \\
\hline HGX32 & 176.9 o & 4 & 62.2 & 55.5 & 4.4 & 300 & 450 & 40.7 & 172.8 & 30.7 \\
\hline HGX30 & 177.7 o & 4 & 9.4 & 40.1 & 4.8 & 300 & 450 & 74.1 & 248.7 & 15.9 \\
\hline $\mathrm{HGX} 28$ & $179.1 \circ$ & 4 & 57 & 19.1 & 3.8 & 300 & 450 & 32.2 & 204.3 & 29.9 \\
\hline HGX24 & 179.7 o & 4 & 56.1 & 33.8 & 1.7 & 300 & 450 & 37.9 & 196.2 & 22.7 \\
\hline HGX18 & 181.9 o & 4 & 48.3 & 35 & 5 & 300 & 450 & 44.5 & 200.6 & 16.2 \\
\hline HGX16 & 182.5 o & 4 & 64.2 & 35.5 & 2.6 & 300 & 450 & 32 & 190.1 & 29 \\
\hline HGX13 & 185.6 o & 4 & 38.5 & 37.7 & 6.5 & 300 & 450 & 53.2 & 205.9 & 8.4 \\
\hline HGX10 & 191.2 o & 4 & 183.2 & -46.7 & 4.7 & 300 & 450 & -81 & 83.3 & 157.8 \\
\hline HGX9 & 191.5 o & 4 & 236.8 & -34.2 & 2 & 300 & 450 & -37.5 & 15.5 & 156.8 \\
\hline BG1 & 193.4 o & 4 & 241.2 & -16.2 & 2.9 & 300 & 450 & -27.9 & 22.8 & 145.2 \\
\hline $\mathrm{BG} 2$ & 193.8 o & 4 & 208.2 & -21.3 & 1.1 & 300 & 450 & -54 & 49.7 & 166.1 \\
\hline BG4 & 194.7 o & 4 & 239.7 & -20 & 9.6 & 300 & 450 & -30.4 & 22 & 148.6 \\
\hline 17ХХT07A & 1950 & 4 & 213.8 & -53.2 & 7.7 & 480 & 640 & -62.4 & 7.4 & 161.6 \\
\hline 17ХХT06А & 1970 & 9 & 254.2 & -19.4 & 5.5 & 300 & 640 & -18.6 & 13.1 & 136.9 \\
\hline BG14 & $198.7 \circ$ & 4 & 200.5 & -18.3 & 0.8 & 300 & 450 & -57.1 & 62.3 & 161.7 \\
\hline 17XXT04A & 199.5 o & 9 & 234.3 & -29.2 & 8 & 300 & 640 & -37.7 & 20.4 & 157.4 \\
\hline BG18 & $201.3 \circ$ & 4 & 234.5 & -13.6 & 2 & 300 & 450 & -32.3 & 28.8 & 148.1 \\
\hline BG22 & 204.10 & 4 & 239 & -18.8 & 1.1 & 300 & 450 & -30.5 & 23.1 & 148.4 \\
\hline 17XXT01A & 2060 & 9 & 38.4 & 39.5 & 7.3 & 300 & 640 & 54 & 204.2 & 9 \\
\hline BG26 & 206.10 & 4 & 60.8 & 44.4 & 0.7 & 300 & 450 & 37.9 & 185.2 & 26.2 \\
\hline BG28 & $207.3 \circ$ & 4 & 74.5 & 53.5 & 1.4 & 300 & 450 & 30.8 & 170.1 & 36.8 \\
\hline BG30 & 207.9 o & 4 & 22.6 & 45.7 & 5.3 & 300 & 450 & 68.7 & 211.6 & 11.4 \\
\hline \multicolumn{11}{|l|}{45 cutoff } \\
\hline $16 \times X J 001 \mathrm{~A}$ & $0.05 \circ$ & 7 & -59.6 & 21.8 & 6.9 & 320 & 650 & 31 & 2.6 & 76.1 \\
\hline $16 \times X J 003 \mathrm{~A}$ & $13.1 \mathrm{o}$ & 7 & 99.8 & -35.4 & 1.2 & 320 & 650 & -19.1 & 202.5 & 96.9 \\
\hline 16XXJ006A & $16 \circ$ & 7 & 259.4 & -17.9 & 5.3 & 320 & 650 & -13.9 & 10.7 & 131.8 \\
\hline $16 \mathrm{XXJ022A}$ & 40.30 & 7 & 261.4 & -15.3 & 7.9 & 320 & 650 & -11.5 & 10.6 & 128.9 \\
\hline $16 \mathrm{XXJ023 \textrm {A }}$ & 41.10 & 7 & 256.8 & -12.6 & 5.4 & 320 & 650 & -14.4 & 14.6 & 131 \\
\hline 16XXJ025A & 42.90 & 7 & 258.8 & -9.6 & 3.8 & 320 & 650 & -11.8 & 14.6 & 127.6 \\
\hline 16XXJ035A & 51.9 o & 5 & 79.1 & -1.1 & 2.6 & 320 & 520 & 8.4 & 198.9 & 59.5 \\
\hline 16XXJ054A & 680 & 6 & 268.2 & -49.6 & 2.3 & 320 & 520 & -18.9 & 347.5 & 134.9 \\
\hline 16XXJ065A & 10.7 o & 5 & 267.6 & 0.5 & 3.2 & 300 & 450 & -1.8 & 13.5 & 114.5 \\
\hline 17XXJ04A & 810 & 9 & 265.9 & -21.7 & 6 & 300 & 640 & -9.9 & 5.1 & 128.5 \\
\hline $17 X X J 05 A$ & 820 & 9 & 266.1 & -6.8 & 6.4 & 300 & 640 & -5.2 & 11.5 & 120.2 \\
\hline $17 X X J 20 A$ & 940 & 3 & 262.3 & -13.5 & 3.9 & 560 & 640 & -10.2 & 10.9 & 127.1 \\
\hline $17 X X J 21 A$ & 95.25 o & 9 & 119.9 & -18.7 & 4.5 & 300 & 640 & -29.6 & 181.4 & 101.7 \\
\hline $17 X X J 25 A$ & 980 & 9 & 231.4 & 4.9 & 7 & 300 & 640 & -28.4 & 39.3 & 134.5 \\
\hline 17XXТ03A & 201.5 o & 9 & -76 & -42.6 & 3.6 & 300 & 640 & -4.1 & 344 & 122.7 \\
\hline 17XXT05A & 1990 & 9 & -76.9 & -14.7 & 5 & 300 & 640 & 5.9 & 358 & 110.9 \\
\hline 17XXT08A & 192 o & 9 & -62 & -41.2 & 3.1 & 300 & 640 & 6.1 & 336.3 & 112.7 \\
\hline 17ХХT09A & 190 o & 9 & -30.1 & 66.6 & 11.4 & 300 & 640 & 64.9 & 51.3 & 45.7 \\
\hline BG6 & 195.8 o & 4 & 251.8 & -10 & 1.6 & 300 & 450 & -17.6 & 18.8 & 133.3 \\
\hline BG8 & 196.8 o & 4 & 252.2 & 3.7 & 5.4 & 300 & 450 & -13.1 & 24.2 & 123.6 \\
\hline BG10 & $197.8 \circ$ & 4 & 245.9 & -4.1 & 3.6 & 300 & 450 & -20.5 & 25.1 & 133.6 \\
\hline BG12 & 198.5 o & 4 & 265.9 & 0 & 2.8 & 300 & 450 & -3.3 & 14.3 & 116.1 \\
\hline BG16 & 200.4 o & 4 & -83.6 & -27.8 & 1.2 & 300 & 450 & -3.7 & 356.2 & 122.7 \\
\hline BG20 & $203.1 \circ$ & 4 & 266.7 & -30.9 & 2.8 & 300 & 450 & -12.4 & 0.2 & 131.7 \\
\hline BG24 & 205.2 o & 4 & -34.8 & 4.5 & 4.3 & 300 & 450 & 43.1 & 333.2 & 65.7 \\
\hline HGX2 & 194.7 o & 4 & 240 & 0.3 & 4 & 300 & 450 & -23.6 & 31 & 133.9 \\
\hline
\end{tabular}




\begin{tabular}{|c|c|c|c|c|c|c|c|c|c|c|}
\hline HGX3 & 194.1 o & 4 & 239.1 & 28.8 & 4.6 & 300 & 450 & -13.9 & 43.5 & 109.8 \\
\hline HGX8 & 191.7 o & 4 & 234.6 & 22.2 & 10.2 & 300 & 450 & -19.7 & 43.8 & 117.5 \\
\hline HGX34 & 175.9 o & 4 & 227 & 14.1 & 9.9 & 300 & 450 & -28 & 46.6 & 127.7 \\
\hline HGX38 & 173.7 o & 4 & 263.8 & -0.8 & 1.6 & 300 & 450 & -5.3 & 15.3 & 118.3 \\
\hline HGX45 & 170.3 o & 4 & 268 & -15 & 5.2 & 300 & 450 & -6.1 & 6.9 & 123.4 \\
\hline HGX46 & 169.7 o & 4 & 261.9 & -11.1 & 3.7 & 300 & 450 & -9.8 & 12.2 & 126.1 \\
\hline HGX56 & 165.1 o & 4 & 263.3 & -16.1 & 4.5 & 300 & 450 & -10.2 & 9.2 & 127.7 \\
\hline HGX62 & 161.5 o & 4 & 203.6 & 48.8 & 4.5 & 300 & 450 & -20.2 & 80.2 & 95.9 \\
\hline HGX66 & 158.8 o & 4 & -80.4 & 7.3 & 4.5 & 300 & 450 & 9.8 & 9.1 & 101 \\
\hline HGX68 & 156.3 o & 4 & 229.2 & 39.7 & 7.8 & 300 & 450 & -14.9 & 55.5 & 102.7 \\
\hline HGX77 & 149.9 o & 4 & 244.5 & 25 & 2.3 & 300 & 450 & -11.7 & 38.1 & 110.8 \\
\hline HGX90 & 139.2 o & 4 & 150 & 74.6 & 2.3 & 300 & 450 & 10.7 & 116.1 & 63.7 \\
\hline HGX102 & 127.7 o & 4 & 79.2 & 18.2 & 2.9 & 300 & 450 & 14.2 & 190.7 & 47.8 \\
\hline
\end{tabular}

